MINISTÉRIO DA EDUCAÇÃO

UNIVERSIDADE FEDERAL DA GRANDE DOURADOS

PROGRAMA DE PÓS-GRADUAÇÃO EM LETRAS

ANA PAULA OLIVEIRA E FERNANDES

DIFERENÇAS ENTRE FALA E ESCRITA DO SURDO: REFLEXÕES TEÓRICAS SEGUNDO UMA EXPERIÊNCIA PRÓPRIA

DOURADOS - MATO GROSSO DO SUL 


\title{
DIFERENÇAS ENTRE FALA E ESCRITA DO SURDO: REFLEXÕES TEÓRICAS SEGUNDO UMA EXPERIÊNCIA PRÓPRIA
}

\author{
Dissertação apresentada ao Programa de Pós-Graduação \\ em Letras, da Universidade Federal da Grande \\ Dourados, como requisito parcial para a obtenção do \\ título de Mestre em Letras, Área de concentração: \\ Linguística e Transculturalidade.
}

Orientadora: Profa. Dra. Rita de Cássia Aparecida Pacheco Limberti 
DADOS INTERNACIONAIS DE CATOLOGAÇÃO NA PUBLICAÇÃO (CIP)

Ficha catalográfica elaborada pela Biblioteca Central - UFGD @ Todos os direitos reservados. Permitido a publicação parcial desde que citada a fonte. 


\title{
DIFERENÇAS ENTRE FALA E ESCRITA DO SURDO: REFLEXÕES TEÓRICAS SEGUNDO UMA EXPERIÊNCIA PRÓPRIA
}

\author{
DISSERTAÇÃO PARA OBTENÇÃO DO GRAU DE MESTRE \\ PROGRAMA DE PÓS-GRADUAÇÃO EM LETRAS - PPGL/UFGD
}

Aprovada em de de

BANCA EXAMINADORA:

Presidente e orientadora:

Rita de Cássia Pacheco Limberti - (Dra. - Facale /UFGD)

$2^{\circ}$ Examinador

Gicelma da Fonseca Chacarosqui Torchi - membro titular interno (Dra. - Facale/UFGD)

$3^{\circ}$ Examinador:

Marilda Moraes Garcia Bruno- membro titular externo) (Dra. - Faed/UFGD)

Rodrigo Rosso Marques - membro suplente externo - (Dr. - UFSC 
A Deus por permitir "ouvir" através dos meus olhos; Aos meus pais, pela nobreza da educação recebida; Ao vovô Ramão (in memoriam), por me permitir dar continuidade às obras de ser professor e escritor; À comunidade surda, pela nobreza da luta pela preservação da Língua de Sinais 


\section{AGRADECIMENTOS}

Em primeiro lugar, quero muito agradecer a Deus porque nunca se ausentou em minha vida, mesmo naqueles momentos de "quase morte", Ele permitiu a oportunidade de continuar minha missão na Terra. E Deu-Me a oportunidade maravilhosa de "ouvir" pelos olhos, pois dos olhos, me tornou o espelho entre as fronteiras dos mundos ouvintes e surdos.

Ao Papai Paulo e à Mamãe Fátima, durante muito tempo, sofreram carregando culpa pelo acontecimento em que fiquei surda, mas quero que vocês se libertam desse sentimento de culpa, pois hoje estou bem! Estou realizada! Venci muitas barreiras, preconceitos, discriminações pelo fato de ser surda e tudo isso são os resultados pela dedicação e educação que recebi através de vocês, no qual principalmente à Mamãe Fátima, que represento você nesta dissertação, como resultados do meu sucesso!

À professora do primeiro ano do Ensino Fundamental, Cida, pela oportunidade de ter me aceito na escola e me instruído à leitura e escrita.

À minha linda filha Ana Sophia, minha vida, minha riqueza, meu orgulho!

À professora Rita pela oportunidade de me aceitar, mesmo sendo um mundo desconhecido, mas não me deixou sozinha.

A todos os professores com quem tive as disciplinas do Mestrado, pois tivemos a oportunidade de conhecer e compartilhar muitas experiências visuais sobre os surdos. E também ao Programa de Mestrado, a oportunidade de me aceitaram, como Pessoa Surda.

Às intérpretes Alexandra, Gilliard, Rejane e Silvana pelas paciências das interpretações em LIBRAS e também compartilhar conhecimentos e novos sinais léxicos para cada disciplina.

Enfim, a todos os surdos por me permitir compartilhar nossas experiências, nossa língua, nossa cultura!

Viva a todos nós Surdos!!!! 
"Que importa a surdez do ouvido, se o espírito continuar a ouvir. A verdadeira e incurável surdez é a surdez do espírito" Victor Hugo 


\section{LISTA DE ILUSTRAÇÕES}

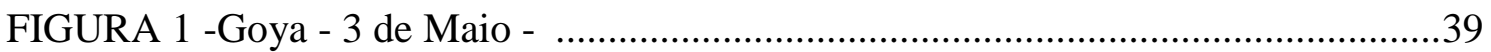

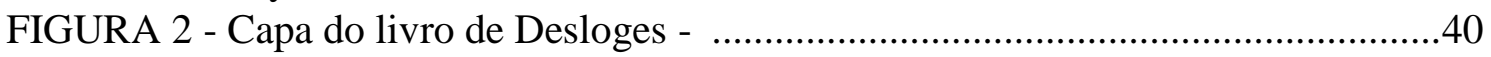

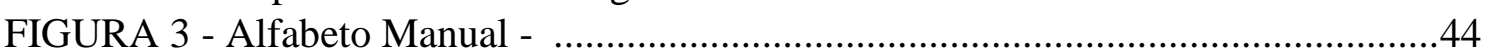

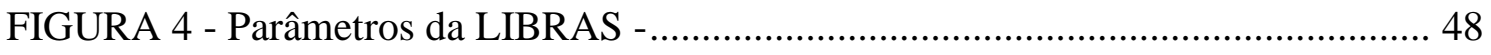

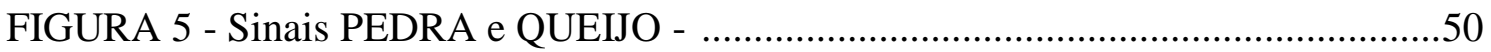

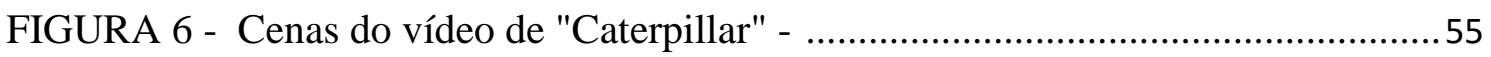

FIGURA 7 - Atividade de $1^{\mathrm{a}}$ série - Ana Paula - 1987 ..................................................63

FIGURA 8 - Atividades diárias - Ana Paula - 1987 .......................................................67

FIGURA 9 - Atividade de avaliação -Ana Paula - 29 de junho de 1987 .......................69

FIGURA 10- Atividade prova - Ana Paula - 23 de junho de 1987 .................................71

FIGURA 11- A imagem do aparelho auditivo mostrava a minha imagem de pessoa

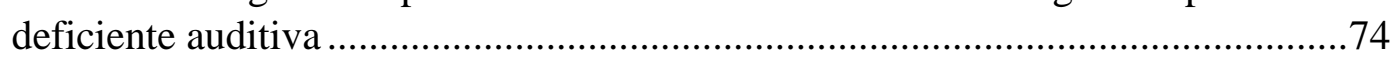

FIGURA 12 - Teatro Cia Camaleão - A bruxinha que era Boa, Maria Clara Machado -

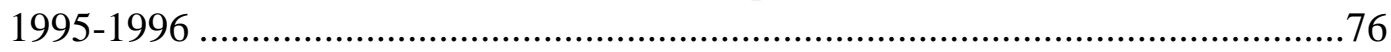

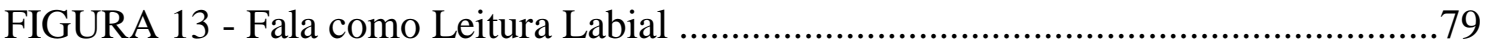

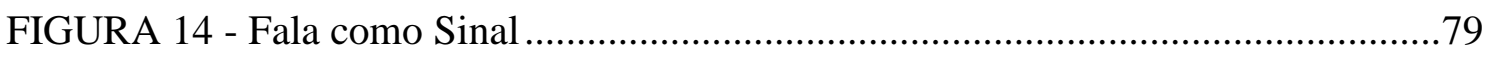




\section{RESUMO}

\section{DIFERENÇAS ENTRE FALA E ESCRITA DO SURDO: REFLEXÕES TEÓRICAS SEGUNDO UMA EXPERIÊNCIA PRÓPRIA}

Há incontáveis histórias marcantes sobre a pessoa surda em seu percurso de lutas e tentativas de aceitação pela comunidade ouvinte. Minha vida tem se tornado uma sucessão de desafios, de descobertas, de estranhamentos, de tentativas de compreender o mundo separatista entre os ouvintes e os surdos. Tive uma vida cheia de desafios, pois vivi as experiências de conhecer o preconceito, a discriminação e a resistência à aceitação pelo fato de eu ser surda. Sabia visualizar muitas coisas, mas tinha anseio em entender o que eu via, a realidade, o sentido da interação entre as pessoas. Queria entender o que as pessoas diziam. Qual o sentido e significado da sua fala? O objetivo desta pesquisa consiste na análise do discurso e fenomenologia sobre ser surda, além das possibilidades de compreensão entre os dois mundos: dos surdos e ouvintes. Busquei através da metodologia de análise teóricas a partir da minha própria vivência, posso relatar sobre o fenômeno de ser surda e sobre a capacidade de conseguir me comunicar entre os dois mundos. Espero que nesta dissertação eu possa descortinar que a Língua de Sinais foi a responsável pela minha evolução em todos os aspectos.

Palavras-chaves: Análise do discurso; fenomenologia; surdez; pessoas surdas; língua de sinais. 


\section{ABSTRACT \\ DIFFERENCES BETWEEN SPEECH AND WRITING OF THE DEAF: THEORETICAL REFLECTIONS ACCORDING TO NA OWN EXPERIENCE}

There are countless remarkable stories about deaf person in his journey of struggle and acceptance of attempts by the listener community. My life has become a series of challenges, discoveries, of strangeness, attempts to understand the breakaway world between listeners and deaf. I had a life beyond challenges as the lived experience of knowing the prejudice, discrimination and resistance to the acceptance of my being deaf. I did see many things, but he was longing to understand what I saw, the reality, and the sense of interaction between people. I wanted to understand what people were saying. What is the meaning and significance of his speech? The objective of this research is the discourse analysis and phenomenology about being deaf, and of the possibilities of understanding between the two worlds of the deaf and hearing. I searched through the theory analysis methodology from my own experience, I can report on the phenomenon of being deaf and the ability to get me to communicate between the two worlds apart. It is hoped that this thesis may uncover in the Signal Lingua was responsible for my development in all aspects.

Key words: discourse analysis; phenomenology; deafness; deaf; sign language. 


\section{SUMÁRIO}

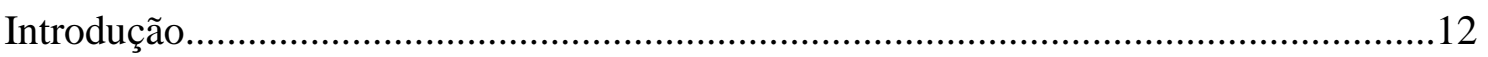

Capítulo 1- A contextualização da Surdez e das Pessoas Surdas.....................................16

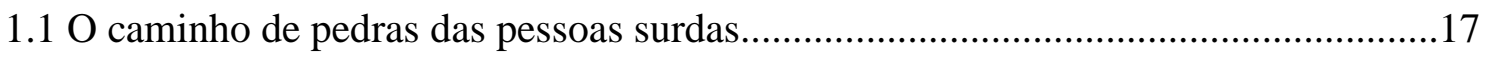

1.2 A Idade Média e surgimento da Educação de surdos...............................................19

1.3 A tentativa de apagamento da Língua de Sinais e Ser Surdo..................................22

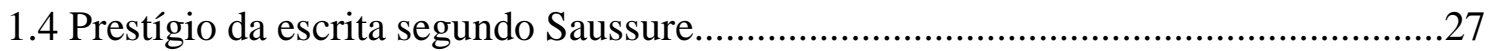

Capítulo 2 - Considerações Teóricas......................................................................... 31

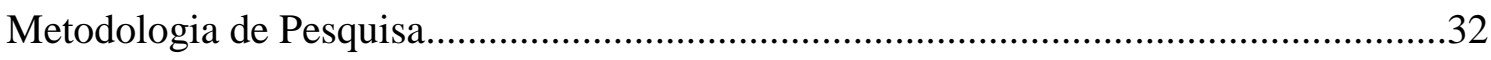

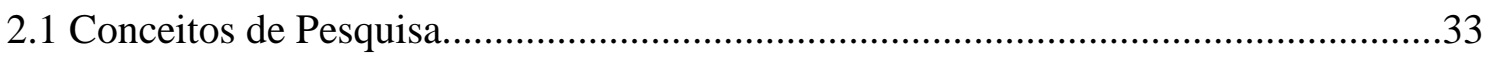

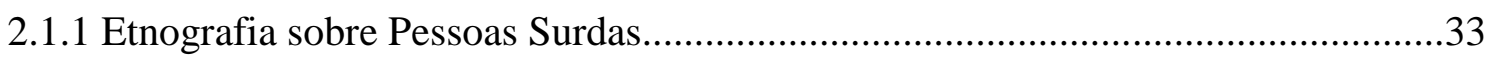

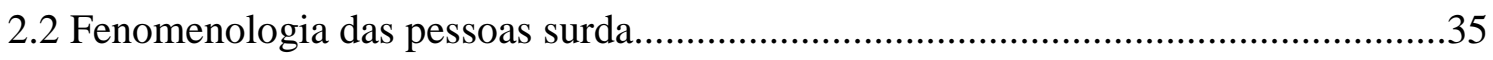

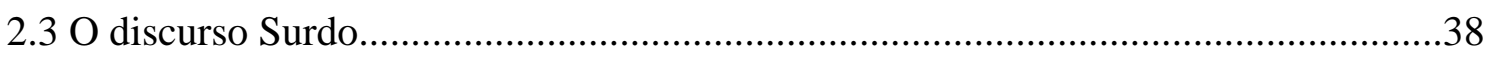

2.4 Reflexões de Benveniste sobre a Língua de Sinais.................................................42

2.5 Conceito de "texto" sobre a Língua de Sinais pela Semiótica Russa de Lótman........53

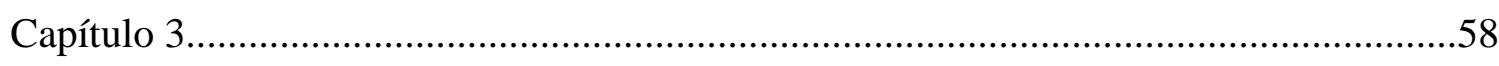

3.1. Me ver" significa "Me ouvir" e "Te ver" significa "Te ouvir" ................................59

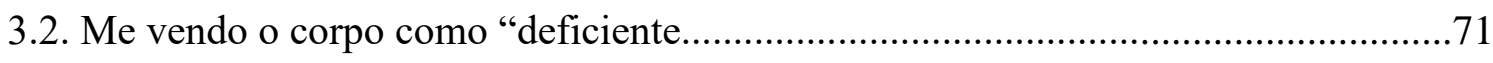

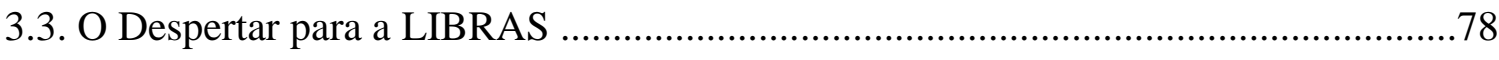

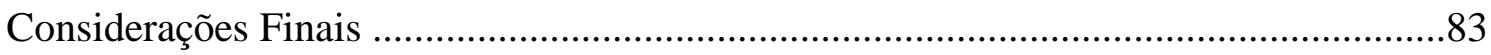

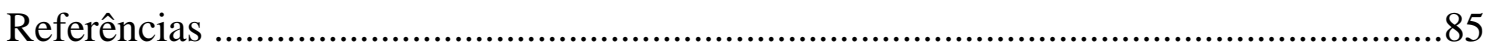

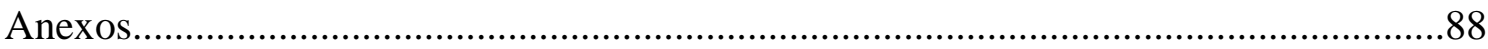




\section{INTRODUÇÃO}

As pessoas surdas enfrentam inúmeros entraves para participar da vida social e educacional decorrentes de sua própria condição de surdez e das formas pelas quais a educação e a sociedade atual se estruturam, assim como também ao desconhecimento em relação aos seus direitos reconhecidos pela Lei $n^{\circ} 10436 / 2002^{1}$, quais sejam: o direito de se expressar e ter o reconhecimento da LIBRAS (Língua Brasileira de Sinas) como sua língua. Os surdos já são constituídos como comunidade, portanto possuem cultura e língua diferentes da comunidade ouvinte.

Por muito tempo a surdez era considerada como uma "falha" humana e era necessário “corrigir, descartar ou curar" a pessoa para integrá-la na comunidade ouvinte. Através do ouvintismo $^{2}$ foram criadas práticas de "normalização" do surdo como a metodologia educacional Oralista segundo a qual o surdo teria que aprender a "fala oral e ouvir". A língua de sinais sempre fez parte da história, mesmo em registros ocultos, os quais a maioria foi repassada de geração em geração de surdos através dos tempos na forma da sinalidade ${ }^{3}$, sendo poucos os registros escritos sobre a língua de sinais. Porém, para a língua de sinais foi (e ainda é de acordo com os pensamentos de pessoas leigas a respeito da língua de sinais ou da pessoa surda) muito difícil obter aceitação e o reconhecimento de seu status linguístico.

Há incontáveis histórias marcantes sobre a pessoa surda em seu percurso de lutas e tentativas de aceitação pela comunidade ouvinte. Para se ter uma ideia, na antiguidade chinesa os surdos eram lançados ao mar e os gauleses os sacrificavam ao deus Teutates por ocasião da Festa do Agárico. Em Esparta os surdos eram jogados do alto dos rochedos, em Atenas eram rejeitados e abandonados nas praças públicas ou nos campos; os surdos não eram considerados seres humanos competentes; dizia-se que sem a fala não se desenvolveria o pensamento. Aristóteles falava que a linguagem era o que dava a condição de humano ao indivíduo; para os Romanos, os surdos que não falavam não tinham direitos legais, não podiam fazer testamentos e precisavam de um curador para todos os seus negócios, pois eram considerados incapazes de gerenciar seus atos, perdiam sua condição de ser humano e eram confundidos com o retardado. A igreja católica, até a Idade Média, acreditava que os surdos

\footnotetext{
${ }^{1}$ Lei Brasileira que reconhece a Libras como meio de comunicação das Pessoas Surdas. www.planalto.gov.br/ccivil_03/leis/2002

${ }^{2}$ Termo usado por Skliar, que representa uma ideologia em que acredita que os surdos devem ser adquiridos a língua oral e também o usos constante de medicalização (usos de aparelhos auditivos e implante coclear) como formas para a cura do corpo deficiente. Lane também explana bem essa terminologia, mas fala em audismo.

${ }^{3}$ Irei explanar esse conceito no capítulo 1, pagina 26.
} 
não tinham alma, por isso não poderiam ser considerados imortais porque esses cidadãos não podiam falar em sacramentos.

Apesar dos desprezos e da rejeição da pessoa surda, houve uma época em que começase a perceber, por meio das formulações de Sócrates, considerações que despertaram curiosidade nas pessoas: "Suponha que nós não tenhamos voz ou língua e queiramos indicar objetos um ao outro. Não deveríamos nós como os surdos, fazer sinais com as mãos, a cabeça e o resto do corpo? "4. A partir dessa fala, houve mudanças históricas em relação à pessoa surda que passa a ser tratada com "caridade" pelas pessoas ouvintes, principalmente nas questões religiosas e "despertares milagrosos", que constituíam "a cura", momento em que a pessoa surda passa a se comunicar, de seu mundo surdo, com o ouvinte. Pessoas ouvintes passam a relatar "curas" sobre a pessoa surda, assim como alguns casos proporcionam a legitimidade da pessoa surda quando se passa a reconhecer os "gestos"(sinais) como meios de comunicação.

Segundo Ladd (2013), em artigo que retrata os discursos sobre as pessoas surdas durante o século XII, apesar de mencionar poucas referências sobre as pessoas surdas, a elas seria permitido casar ou receber heranças. Em alguns casos, pessoas ricas pagavam a ordens monásticas para tomar conta dos filhos surdos e também dar-lhes educação. Esses acontecimentos eram geralmente em algumas ordens monásticas que pregavam o culto do acordo ao silêncio estabelecido nos mosteiros. É bem provável que, dentro desses mosteiros, a língua de sinais era muito utilizada como ritual do silêncio. Desta possibilidade, os surdos podiam receber educação, leitura, pinturas, comunicação, além de saber arquitetura, geometria, história sagrada e profana. Especialmente na França, naquele período, podiam-se ver "casos de cura" da comunicação dos surdos com os ouvintes (LADD, 2013. pag. 48-49). Muitos discursos partem dos ouvintes registrando esses acontecimentos "milagrosos" em que um surdo é visto como um milagre por ter sido possível a ele se comunicar, falar e adquirir linguagem.

Em poucos momentos da história antiga a pessoa surda narra-se como protagonista de sua própria história. Apenas na Idade Contemporânea a pessoa surda passa a ser referência para a sua comunidade através de registros em que surdos passam a ser professores de surdos, como exemplo, Jean Massieu, que atuou entre os séculos XVIII e XIX, época de grandes

${ }^{4}$ História da Educação de Surdos - UFSC -

www.libras.ufsc.br/colecaoLetrasLibras/eixoFormacaoEspecifica/historiaDaEducacaoDeSurdos/assets/258/Text oBase_HistoriaEducacaoDeSurdos.pdf 
mudanças, revoluções, novas ideias e transformações sociais. A partir deste, outros professores surdos passam a atuar como referências de grandes transformações na comunidade surda. Assim, os surdos conseguem marcar presença histórica através da escrita em seus registros sobre a educação de surdos, a partir do século XVII, onde foi possível, através de Charles Michel L’Éppe, reconhecer a Língua de Sinais como comunicação entre surdos e ouvintes. Desses registros escritos, os surdos passam a defender a Língua de Sinais como língua, assim como Jean Massieu e Pierre Desloges, que escreveram um pequeno livro defendendo a Língua de Sinais e os métodos de Educação formulados por L'Éppe. ${ }^{5}$

Neste trabalho de pesquisa busco refletir de onde vem a discriminação da pessoa surda: vem de sua língua de sinais, de sua escrita, ou de sua condição de sujeito surdo? Através de experiências próprias, enquanto surda, busco por meio das teorias científicas conduzir meu olhar sobre as experiências linguísticas fenomenológicas adquiridas durante minha infância até a descoberta da LIBRAS. Para a língua de sinais foi (e ainda é, de acordo com o pensamento de pessoas leigas a respeito da pessoa surda) muito difícil obter aceitação e o reconhecimento do status linguístico de que ela usufrui na atualidade.

Mesmo tendo graus profundos de surdez (de acordo com o CID 90 - Surdez neurosensorial profunda, praticamente "zero" de capacidade auditiva), oralizada ${ }^{6}$ e sinalizada: como consegui adquirir a escrita? Como foi possível desenvolver minha linguagem? Em minhas memórias, não me lembro de "ouvir oralmente" as palavras e relacioná-las com a escrita. Tudo que eu via era a relação "Imagem x Escrita", operava-se em minha mente a memorização da escrita e principalmente o processo de relacionar o significado de cada palavra a seus sentidos e usos na relação social com os simples "apontamentos de dedos" sobre a imagem ou ação.

Minha experiência de linguagem foi de uma época em que não existia a política de inclusão nem intérpretes ou a língua de sinais, muito menos programas ou ações de apoio. Era uma época em que a hegemonia da fala, da leitura labial e da prática do ouvir eram dominantes, assim como nos tempos após o fatídico Congresso de Milão de 1880, onde a educação de surdos foi determinada apenas na vocalidade do oralismo. Por que ocorreu essa hegemonia da oralidade? Para Ladd (2013), a exigência das tentativas de integração social na comunidade ouvinte era (e ainda é) uma prática das tentativas de aceitação de um corpo diferente na sociedade majoritária: 
[...] o olhar Surdo é atraído, não para a existência da educação por si, mas para a proeminência dada ao 'milagre' da fala e leitura labial. Isso sugere-nos a existência de um outro discurso, os Surdos podem muito bem ter sido encarados como completamente humanos, de forma que a educação aperfeiçoa simplesmente a qualidade da sua humanidade. De acordo com esse discurso, não é que a fala e leitura labial sirvam de prova de inteligência, como os educadores diriam, mas antes como uma competência auxiliar inesperada. (Ladd 2013, pag. 58)

Poderia então ter sido uma competência auxiliar inesperada, uma sobrevivência humana ao ambiente social linguístico? Como seria esse acontecimento? Lembro-me de minha fase de "ausência da língua", quando eu apenas vivia na visualidade das coisas e ações, sempre existiram perguntas quando eu visualizava pessoas conversando na linguagem oral, como por exemplo: o que está acontecendo? O que as pessoas estão fazendo? Para que serve isso? Porque é assim? Porque tem que ser assim? Isso perdurou até que eu descobrisse a Língua Brasileira de Sinais (LIBRAS) que me provocou um despertar para a razão de viver.

Portanto o problema da pesquisa é sobre qual é a diferença das visões de fronteiras de uma experiencia própria de pessoa surda, diante da diferença em que a pessoa ouvinte se vivência sobre o outro, de como foi a vivência da essência em que tive as experiencias de aquisição de mundo entre surdo e ouvinte.

A pesquisa está ancorada na abordagem descritiva baseada na fenomenologia hermenêutica, pois estudarei minha própria experiência de ser surda, como adquiri minha língua, minha linguagem, minha escrita e como adquiri a LIBRAS como o último fenômeno da essência, o despertar da comunicação entre os mundos ouvinte e surdo, quebrando as fronteiras da comunicação (CRESWELL, 2014). O Sujeito Surdo, a história da comunidade surda, a Língua de Sinais e a linguagem, dentro das perspectivas metodológicas fenomenológicas, serão tomados como objeto de estudo segundo os preceitos teóricos da Análise de Discurso buscando-se compreender a língua não só como estrutura, mas um acontecimento, uma experiência viva da interação social, principalmente da pessoa surda.

É desta maneira que pretendo me questionar sobre a minha vivência entre os mundos ouvinte e surdo; a vivência de ter adquirido a comunicação, a vivência de ter adquirido a escrita e a vivência de ser surda e ser aceita pela comunidade tanto ouvinte como surda. Esses questionamentos levaram-me à Língua de Sinais e sua valorização enquanto corpus, pois foi esta língua que adquiri mesmo em idade avançada que me possibilitou a quebra das fronteiras entre as comunicações surdas e ouvintes; inclui-se neste corpus os relatos de experiências de pessoas envolvidas na minha formação intelectual, comunicativa e cultural. 


\section{CAPÍTULO 1}

A CONTEXTUALIZAÇÃO DA SURDEZ E DAS PESSOAS SURDAS 
Neste capítulo relatarei sobre as reflexões a respeito da surdez e da situação das pessoas surdas se originam das perguntas que me acompanham há muito tempo: O que é ser surda em um mundo onde os ouvintes são a maioria? O que significa cada movimento dos seus lábios? Será que tem um balão invisível e que só eu não consigo ver? O que é a Surdez? O que é Língua de Sinais? O que é a oralidade?

Muitas vezes não conhecemos a contextualização da identidade surda, da cultura e de sua língua de sinais. As pessoas surdas enfrentavam inúmeros entraves ao longo da história da humanidade. É necessário conhecer um pouco, quem é a pessoa surda, como é possível fazer ela ter uma comunicação baseada nos sinais? Há mitos e verdades sobre a pessoa surda.

Minha vida tem se tornado uma sucessão de desafios, de descobertas, de estranhamentos, de tentativas de compreender o mundo separatista entre os ouvintes e os surdos. Tive uma vida repleta de desafios, pois vivi as experiências de conhecer o preconceito, a discriminação e a resistência à aceitação do meu ser surda. Durante muito tempo, minha vida foi tomada por desconhecimento a respeito do mundo exterior. Sabia visualizar muitas coisas, mas tinha anseio de entender o que eu via, a realidade, o sentido da interação entre as pessoas. Queria entender o que as pessoas diziam. Qual o sentido e significado da sua fala? Porque estavam rindo? O que era um cacto? Precisava mesmo saber falar corretamente com a minha voz? Como é a minha voz? E a sua voz? Sempre tantas indagações... mas minha vida passou a ter sentido e eu passei a compreender o mundo exterior a partir da descoberta da LIBRAS.

\subsection{O caminho de pedras das pessoas surdas}

Durante a história da humanidade, as pessoas surdas enfrentaram (e ainda enfrentam) inúmeros entraves para participar da vida social e educacional decorrentes da perda da audição, assim como eu. As formas como se estruturam a educação e a sociedade atual vêm de muitos anos, desde a antiguidade. Pessoas surdas sempre existiram, assim como os preconceitos e a discriminação à sua condição de ser surdo. O simples fato de não poder ouvir impunhou-nos inúmeras restrições, tornou-nos menos humanos e com menos direitos. Além do abandono e também dos genocídios das pessoas surdas e outros deficientes, nossas vidas foram marcadas pela busca da sobrevivência em um mundo difícil.

Relatarei aqui alguns fatos da história da humanidade relacionados às pessoas surdas tentando delinear os percursos do sentido da discriminação e também os episódios de proteção 
e de reconhecimento da pessoa surda para, então, chegar ao sentido de ser discriminado, um fardo que os surdos carregam até hoje.

Há incontáveis histórias marcantes sobre a pessoa surda ${ }^{7}$ em seu percurso de lutas e tentativas de aceitação pela comunidade ouvinte. Curiosamente, em alguns lugares, os surdos já foram considerados deuses, no caso do Egito, no $5^{\circ}$ milênio a.C, quando acreditavam que os surdos podiam ver mensagens dos deuses como intermediários, já que não falavam com a voz. Na verdade, tal concepção era uma forma de os faraós manterem o poder sobre o povo do Egito, já que este via os surdos como seres estranhos, com um jeito de se comunicar diferente; assim, a população tinha medo e pavor dos surdos (CARVALHO, 2007, pag. 08-13).

$\mathrm{Na}$ história judaica, em suas referências registradas sobre os surdos, na Lei Hebraica (Talmude), tem-se o registro da existência dos surdos no ano de 1000 a. C. Tratava-se de uma lei que tirava os direitos dos surdos e ainda os classificava como "surdo-mudo", só "surdo" e só "mudo", impondo-lhes limitações, pois não podiam casar e também herdar propriedades. Mais tarde gregos, romanos, até a Idade Média, adotaram essas ideias.

$\mathrm{Na}$ antiguidade, era muito comum um surdo ser sacrificado em cerimônias de oferendas com o intuito de obter uma melhor coleta de alimentos e proteção ao povo, além de atos de abandono e de rejeição e morte. Sacrificavam não apenas os surdos, mas também outras pessoas com deficiência: na antiguidade chinesa, os surdos eram lançados ao mar, os gauleses os sacrificavam ao deus Teutates, por ocasião da Festa do Agárico. Em Esparta os surdos eram jogados do alto dos rochedos, em Atenas eram rejeitados e abandonados nas praças públicas ou nos campos; os surdos não eram considerados seres humanos competentes.

$\mathrm{Na}$ Grécia, através da filosofia dominante, diziam que sem a fala não se desenvolveria o pensamento. Para eles, a fala desenvolvia a linguagem: era o que dava a condição de humano ao indivíduo. Aristóteles, em 355 a.C, defendeu que os que nasciam surdos não podiam receber educação por não terem linguagem eram incapazes de raciocinar. Sócrates, contudo, foi outro grande filósofo que questionou, em 360 a. C., a condição dos surdos. Ele disse: "Suponha que nós não tenhamos voz ou língua e queiramos indicar objetos um ao outro. Não deveríamos nós, como os surdos, fazer sinais com as mãos, a cabeça e o resto do

\footnotetext{
7 Ao longo da dissertação usarei quatro definições: "pessoas surdas": terminologia usada no sentido geral e também utilizado em artigos de legislações atuais; "pessoas com surdez": terminologia usada no sentido patológico, geralmente é utilizada nas áreas de medicina; "Surdo": Ladd (2003) usa muito essa terminologia, pois está representando a identidade e a cultura surda; Ser surdo; e Marques, também usa essa terminologia como é a essência do corpo surdo, focado na subjetividade. Todas estas quatro terminologias comtemplam as denominações necessárias para melhor abordar o discurso surdo.
} 
corpo?" ${ }^{\prime}$. Sócrates acreditava que era possível aos surdos comunicarem-se naturalmente com as mãos, mas não há registro de que houve de fato a aceitação dos surdos na educação grega.

Para os romanos, os surdos que não falavam não tinham direitos legais, não podiam fazer testamentos e precisavam de um curador para todos os seus negócios, pois eram considerados incapazes de gerenciar seus atos, perdiam sua condição de ser humano e eram confundidos com os retardados. A Igreja Católica, na Idade Média, acreditava que os surdos não tinham alma, por isso não poderiam ser considerados imortais; além disso, esses cidadãos não podiam falar os sacramentos.

O que se pode observar ao longo da história é o fato de que os surdos sempre foram considerados inúteis, descartáveis, como "algo" que não merecia a tentativa de inserção e/ou sobrevivência na sociedade. Paralelamente a isso, observa-se que pessoas ouvintes passam a relatar "curas" sobre a pessoa surda, assim como alguns casos de "legitimação" da pessoa surda quando se passa a reconhecer os "gestos"(sinais) como meios de comunicação.

\subsection{A Idade Média e o surgimento da Educação de surdos}

Os surdos foram muito usados como detentores de milagres durante a Idade Média e Moderna. Carvalho (2007) conta-nos uma história em que houve um primeiro educador de surdo que surgiu em função de ter observado a capacidade de falar de um surdo o simples Pai Nosso. John de Beverley (700 d.C.), um arcebispo inglês, foi surpreendido por um rapaz que o interrompeu enquanto rezava; interessou-se logo, pois percebeu que o rapaz que não ouvia e não falava era esperto. $\mathrm{O}$ arcebispo passou, então, a ensiná-lo a ler e a escrever em segredo. Desse aprendizado, treinou-o a falar a oração do Pai Nosso e então o mandou ir à missa de domingo. $\mathrm{Na}$ frente de muitas pessoas, chamou-o, benzeu sua língua e o rapaz recitou a oração. Diante do fato, muitas pessoas passaram a acreditar nos milagres do arcebispo. Não à toa o surdo começou a receber as instruções, a educação pelo reconhecimento de sua capacidade, mas continuou a ser usado como instrumento de ajuda para "provar" os poderes sobrenaturais de Jesus, pois a surdez foi retratada no Antigo Testamento "como uma indicação que um indivíduo foi possuído por um ser demoníaco, maléfico (LADD, 2013, pag. 48 apud VAN CLEVE \& CROUCH, 1983, pag. 3). Assim, a cura do surdo se torna um ato de salvação pelo fato de que a Igreja considerava o surdo como possuído pelo demônio. Portanto, 
pode-se perceber claramente o uso da pessoa com surdez. "Assim, no âmbito da cristandade, a surdez é usada como um veículo para ajudar 'a provar' os poderes sobrenaturais de Jesus dessa forma, intimamente ligada à raios d'être da própria religião" (LADD, 2013, pag. 48).

$\mathrm{O}$ fato de o surdo ser usado como instrumento de milagres se deve à ideia da "exaltação bíblica da voz e do ouvido como único e verdadeiro modo como o homem pode falar com Deus" (SACKS, 2010, pag. 25), além da premissa máxima do livro de Gênesis que afirma que "no princípio era o Verbo". A exaltação e também as sessões de milagres, embora possam ser consideradas injustas para os surdos por terem sido usados como instrumentos para glorificação e libertação do demônio incorporado no corpo surdo ocasionaram a oferta de uma educação diferenciada e o desenvolvimento de uma multiplicidade de perspectivas educacionais para eles, porém apenas oferecidas por pessoas que eram da classe burguesa e das ordens monásticas.

Nos registros históricos sobre a Idade Moderna, durante o Renascimento, passam a constar referências à educação de surdos sendo que alguns defendiam suas capacidades, outros enfatizavam sua contribuição na disseminação e fortalecimento da fé cristã, enquanto as classes da burguesia se preocupavam em repassar educação e heranças a seus filhos surdos. No caso das ordens monásticas, nos mosteiros em que a fé cristã era baseada no silêncio, aqueles que faziam seu voto só podiam utilizar sinais para se comunicar. Segundo Ladd (2013), é possível que, em algumas dessas ordens, seus sinais tenham sido desenvolvidos a partir das próprias línguas de sinais dos surdos.

É muito raro encontrar registro de pessoas surdas que foram educadas e receberam instruções para professorar, pois nos livros recentes de história dos surdos e sites de internet encontramos informações de que a maioria era pessoas ouvintes ligadas a essas ordens com o único objetivo de trazer a "cura" sobre a pessoa com surdez. Entretanto, através de registros de Ladd (2013), encontra-se um caso de surdo educado pela ordem, Etienne de Fay, o qual mostrou-se notável arquiteto e também tinha outras funções como educador de crianças surdas e administrador da abadia, onde organizava os mantimentos.

Durante os séculos XVII e XVIII há uma revolução de reconhecimento das capacidades das pessoas surdas, inclusive o reconhecimento da Língua de Sinais. Filósofos, médicos e abades passaram a discorrer sobre as capacidades das pessoas surdas de aprender a se comunicar utilizando diversos métodos de comunicação. Nesse mesmo período houve o surgimento de escolas para surdos por meio de Ponce de Leon, primeiro educador de surdos reconhecido mundialmente. Muitos surdos eram primogênitos da nobreza e por isso as famílias entregavam a Ponce de Leon a tarefa de educar. À época, esses surdos aprenderam 
filosofia natural e astrologia, além de aprender a ler e escrever (CARVALHO, 2007, pag. 1725). A maioria das citações encontradas em Carvalho relata ouvintes mostrando e registrando a história da educação de surdos. Ainda é bem raro encontrar livros escritos pelos próprios surdos. O que se destaca na história em relação a surdos que utilizavam a escrita foi o abade Charles Michel de L’Épée que, por razões religiosas, foi responsável por uma mudança revolucionária na capacidade da pessoa surda. Ele se dedicou a aprender e a valorizar a língua nativa dos surdos pobres de Paris para possibilitar uma transformação na comunidade surda. Para muitos, além de ele ser o criador dos "sinais metódicos"9, "'e também considerado o "pai dos surdos", pois passou a ver o surdo como um ser com capacidades inteligíveis, que consegue se comunicar através da Língua de Sinais Francesa e da Língua Oral Francesa. (CARVALHO, 2007, pag. 18-24)

L’Épée conseguiu criar em 1755 uma escola com auxílio público, a primeira escola pública de surdos, que possibilitou o acolhimento de muitos surdos pobres, abandonados e marginalizados pela sociedade. O notável abade dedicou-se à tarefa de formar professores surdos para, assim, continuar a educação pelos "sinais metódicos", surgindo surdos formados em matemática, engenharias e professores de Língua de Sinais. Essa é considerada a época de ouro da educação de surdos. Nesse período, surgem registros nos quais podemos encontrar livros escritos por surdos, como é o caso da obra francesa Observations D'un Sourd et muèt sur uncours élémentaire. D'éducation des sourds et muéts ${ }^{10}$, publicado em 1779, por Pierre Desloges.

Nesse livro é possível mostrar que L’Épée não é o “criador” dos sinais, pois ele faz um relato minucioso sobre a Antiga Língua de Sinais Francesa, segundo o qual ela já existia antes mesmo da invenção do método dos sinais. À época, é possível "ver/ouvir" a voz do surdo nas escritas defendendo a Língua de Sinais numa publicação que teve apenas uma única edição, enquanto o livro de L’Épée teve repercussão internacional:

De acordo com Carvalho (2012):

Para ensinar os surdos, o abade aprendeu Língua Gestual utilizada pelos surdos parisienses, a chamada "Antiga Língua Gestual Francesa" e utilizavaa nas aulas adicionando outros gestos que inventou e que lhe permitiram

\footnotetext{
9“Sinais Metódicos”, segundo SACKS (2010), refere-se a uma combinação da Língua de Sinais Nativa Francesa com a gramática francesa traduzida em sinais. Foi um método tão bem-sucedido que permitiu que alunos surdos lessem e escrevessem em francês proporcionando, assim, seu acesso às maiores obras e também à educação, além do surgimento de intérpretes da língua de sinais francesa.

10Observações de um surdo-mudo1 sobre um curso elementar de educação de surdos-mudos, publicado em 1779 pelo Abade Deschamps, Capelão da Igreja de Orléans. Paris: B. Morin, 1779, ppag. 7-16. Tradução de Daniela Loro
} 
“cunhar" conceitos do francês escrito para os quais, aparentemente, não existiam equivalentes em Língua Gestual. Esta situação deve destacar-se porque durante muito tempo, em todo mundo e mesmo em França, a comunidade surda atribuía a L’Épée a criação da "Langue des Signes Françaises". Todavia, como recorda Piérre Desloges na sua obra de 1779, a LSF já existia muito antes do abade de L’Épée porque já existia em Paris uma comunidade surda bem estabelecida quando o abade abriu a escola.. (Carvalho, 2012, pag. 24):

Sacks (2010, pag. 27-28) nos relata que Desloges mostra um mundo bastante diferente em relação ao que os ouvintes escrevem. Ele relata que a visão de mundo dos surdos sobre a falta de acesso à Lingua de Sinais e mais ainda a falta de interação entre a comunidade surda deixava-o perdido, utilizando gestos isolados e não relacionados, pois faltava-lhes habilidade para formar ideias abstratas devido à ausência da Língua de Sinais. Desloges relata também que aprendeu muito tarde a Língua de Sinais, uma situação idêntica a minha própria vida, pois só tive conhecimento da LIBRAS após a idade adulta. As sensações eram as mesmas, eu vivia em dúvida em relação à oralidade, as ideias não eram perceptíveis, não eram compreensíveis. Como diz Desloges:

\begin{abstract}
A língua [de sinais] que usamos entre nós, sendo uma imagem fiel do objeto expresso, é singularmente apropriada para tornar nossas ideias acuradas e para ampliar nossa compreensão, obrigando-nos a adquirir o hábito da observação e análise constante. Essa língua é vívida; retrata sentimentos e desenvolve a imaginação. Nenhuma outra língua é mais adequada para transmitir emoções fortes e intensas. (SACKS, 2010, pag. 29)
\end{abstract}

Mas a época de ouro, em que houve professores surdos e vicejou o uso da Língua de Sinais, durou muito pouco, pois na época existiam pessoas contrárias à Língua de Sinais, que criaram outras técnicas, como era o caso da oralidade, sobre a qual discorrei a seguir.

\title{
1.3 A tentativa de apagamento da Língua de Sinais e Ser Surdo
}

A oralidade surgiu nessa mesma época de L’Épée; alguns defendiam que o surdo deveria ser oralizado para melhor interagir na sociedade em geral. Jacob Rodrigues Pereira e Samuel Heinicke criticavam o método de L’Épée tendo mantido com ele uma discussão ao longo da vida do estudioso. Eles acreditam que os surdos deveriam primeiro aprender a falar e depois a escrever, tal como as crianças ouvintes. Seu grande objetivo era fazer os surdos falarem vocalmente.

O que me surpreende é que, ainda hoje, observamos o fato de que as pessoas ouvintes são colonizadoras das pessoas surdas, pois toda a divulgação dos saberes da educação e 
também os métodos da Língua de Sinais foram escritos por ouvintes, sendo restritos o acesso e a divulgação das obras escritas por surdos. Há poucos livros e obras escritas por pessoas surdas, pois não foram preservadas, ou mesmo foram perdidas.

As pessoas surdas voltam a ser vistas como seres humanos inferiores, as relações entre os sujeitos ouvintes e surdos se estabelecem de modo a considerar o corpo como objeto e alvo de poder. Foucault (1987) retrata bem essa situação de que o homem sempre tentou exercer controle sobre o corpo do outro. É o controle do corpo que "se manipula, que se modela, se treina, que obedece, responde, se torna hábil" para satisfação da busca de poder. Poder sobre o corpo do outro como forma de controle.

De acordo com Foucault (1989, pag. 117):

Houve, durante a época clássica, uma descoberta do corpo como objeto e alvo de poder. Encontraríamos facilmente sinais dessa grande atenção dedicada então ao corpo - ao corpo se manipula, se modela, se treina, que obedece, responde, se torna hábil ou cujas forças se multiplicam. (Foucault 1989, pag. 117)

O "homem-máquina" citado por Foucault, era construído por filósofos como Descartes, que desenvolveu o Método Cartesiano, no qual defende que só se deve considerar algo como verdadeiramente existente caso possa ser comprovada sua existência. Também conhecido como Ceticismo Metodológico, o método segue o princípio de que devemos duvidar de todos os conhecimentos que não possuem explicações evidentes. Este método também se baseia na realização de quatro tarefas: verificar, analisar, sintetizar e enumerar. ${ }^{11}$ Tais conceitos confluíram para a busca pelo corpo ideal, inteligível, corpo útil. Assim foram construídos regulamentos militares, escolares, hospitalares e processos empíricos para controlar ou corrigir as operações do corpo. A concepção de controle do corpo estava presente no Congresso de Milão ${ }^{1213}$, onde se buscava a dominação do surdo pelo ouvintismo, visão que já há muito se difundia em relação ao corpo surdo: ele devia ser "consertado". O acontecimento mais traumático e marcante para a comunidade surda se deu por ocasião do Congresso de Milão de 1880. Os trabalhos e discussões do evento reavivaram as tentativas de genocídio sobre as Comunidades Surdas, como a "morte da Língua de Sinais e Surdos":

$11<$ <ttp://www.suapesquisa.com/quemfoi/descartes.htm>. Acesso em: 09/08/2016.

12 O Congresso de Milão de 1880 foi organizado com o objetivo de determinar uma única educação de surdos. Esteve em conflito as propostas de educação: o oralismo e a língua de sinais. Então foram convidadas 164 pessoas defensores do oralismo e apenas 4 pessoas da língua de sinais, sendo então vitorioso o oralismo. Para nós surdos, foi considerado uma tragédia, onde foi proibido o uso da Língua de Sinais e expulsão de todas as pessoas surdas da educação. 
O Homem-Máquina de La Mettrie é ao mesmo tempo uma redução materialista da alma e uma teoria geral do adestramento, no centro dos quais reina a noção de "docilidade" que une ao corpo analisável, o corpo manipulável. É dócil um corpo que pode ser submetido, que pode ser utilizado, que pode ser transformado e aperfeiçoado. (FOUCAULT, pag. 118, 1987)

Tornar o surdo como "dócil", segundo os princípios do oralismo, tornar o surdo idêntico ao ouvinte, por que isto? Skliar analisa esses acontecimentos, a hegemonia do discurso da deficiência, a prática da discriminação, conhecida como "ouvintismo", a qual vem de muitos anos:

O que é, mais explicitamente, o ouvintismo? Trata-se de um conjunto de representações dos ouvintes, a partir do qual o surdo está obrigado $\underline{\boldsymbol{a}}$ olhar-se e a narrar-se como se fosse ouvinte. Além disso, é nesse olhar-se, e nesse narrar-se que acontecem as percepções do ser deficiente, e não do ser ouvinte; percepções que legitimam as práticas terapêuticas habituais. (SKLIAR, 2005, pag. 15)

No século XVIII e XIX a sociedade em geral passa a ter horror aos surdos; os estudiosos começam a dizimar as línguas de sinais e as comunidades surdas e ainda a utilizar os surdos como experimentos da medicina. A aprovação das oito resoluções do Congresso de Milão afetou gravemente a comunidade surda, sua educação, principalmente com a abolição da Língua de Sinais no mundo. A insistência em destacar o ensino da fala acabou por implicar um descuido da escrita; a prioridade da educação dos surdos consistia, principalmente, em treinos de fala e oralidade. Poucos anos depois já não existiam mais professores surdos e também as Línguas de Sinais; muitas crianças tiveram um retrocesso intelectual e desvantagens na educação devido à baixa capacidade de ler e escrever.

Foram criadas várias abordagens de educação para os surdos após o Congresso de Milão sendo que a primeira é o Oralismo Puro, que foi resultado desse Congresso de 1880. O Oralismo consistia em que o surdo aprendesse a "falar oralmente" numa situação em que se forçava estritamente às práticas clínicas, deixando de lado a educação. A criança surda era constantemente treinada a falar; isso acabou por tornar a educação da criança bastante fragmentada, deixando-a sem ao menos um privilégio de ter uma linguagem normal a todas as crianças. Lane (1992) afirma que esse método resultou em um impacto nos surdos adultos, incapazes de ter uma conversa coerente com outros surdos adultos, que permaneciam “escondidos", usando a língua de sinais.

Assim sendo, o Oralismo era uma abordagem que focava mais uma prática da medicalização na tentativa de a criança surda ser recuperada e inserida na sociedade. Soares 
(2005), em sua pesquisa sobre a educação de surdos no Brasil, observou que a oralidade tinha como meta a forma de comunicação humana apontando - e justificando - a medicina como principal articulador da educação dos surdos.

A subjetividade do Ser Surdo continuou a ser dizimada por mais de 150 anos depois do Congresso. Poucos relatos sobre os surdos ocorreram durante os séculos XIX e XX enfatizando-se apenas a teoria da medicalização da surdez e a volta da declaração de "deficiência". O corpo passa novamente a ser objeto de normalização a partir dos elementos "faltantes" no mesmo. Marques (2007, pag. 82) nos exemplifica a razão da insistência da normalização do corpo surdo em relação ao corpo perfeito:

A questão da deficiência está subjugada às teorias patológicas. Levando a uma análise mecanicista do corpo e de sua devida "correção", ignorando uma concepção de corpo, mutante, flexível, que estabelece autonomia de significações constituintes de sua essencialidade.

A subjugação do corpo surdo e Ser Surdo ainda persiste nos tempos atuais movida por uma ideologia patológica, oralista e ouvintista. Na atualidade ainda persiste a preocupação severa com o fato de que o surdo deve adquirir a escrita como requisito para a reintegração à sociedade. Existem, ainda, as tentativas de fazer o surdo "ouvir", como uma forma de normalização, fazendo com que os mesmos continuem sendo massacrados.

Apesar de eu ser surda somente a partir dos 3 anos de idade, tive poucos resíduos auditivos, não sei o que é exatamente um “ouvir". Preocupa-me se esses meus episódios de ouvir são reais. Provoca-me uma angústia tentar compreender o mundo entre surdos e ouvintes. Mesmo adquirindo a escrita como recurso de ponte entre os dois mundos, continuo tendo barreiras nas fronteiras entre os mundos dos ouvintes e dos surdos.

Após várias tentativas de educação dos surdos pela oralidade houve uma revolução por meio de vários encontros e congressos de educação mostrando a ineficaz abordagem oralista como principal responsável pelos resultados negativos como: incapacidade de leitura, de linguagem e de cognição por parte desse contingente de pessoas. Mas a medicalização ainda permaneceu sob forte influência das pessoas que ainda acreditavam que o surdo seria capaz de ouvir, falar, ler e escrever. Lane (1992, pag. 86) afirma que Foucault analisa a revolução histórica pela qual o controle dos corpos passa até a ser um assunto legítimo do governo. $\mathrm{O}$ conceito é ligado ao sentido de "biopoder", que envolve assuntos em que o governo precisa fazer a parte do controle social de uma comunidade. Assim, para Lane (1992, pag. 86): 
Michel Foucault tem analisado a evolução histórica na qual o controlo dos corpos das pessoas chegou a ser considerado como um assunto legítimo do governo. Aquilo que Foucault chama de "biopoder" estende seu alcance à nossa civilização em campos muito diversos como: criminalidade, psiquiatria, educação e planeamento familiar. No "biopoder", o conhecimento e o poder constituem uma tecnologia reguladora, cujo objetivo é "forjar um corpo frágil que possa ser sujeito usado, transformado e aperfeiçoado".

Apesar de na educação de surdos ter havido mudanças de abordagens educacionais sempre no sentido de minimizar os prejuízos causados pela rejeição e a não aceitação da língua de sinais e também sua habilidade cognitiva e linguística, ainda hoje permanece o discurso audista, em que sempre se procura colonizar o surdo através do poder da medicalização, denominada por Foucault de "biopoder". Mesmo assim a sociedade ainda permanece leiga em relação à Pessoa Surda e sua identidade cultural.

A Língua de Sinais sempre fez parte da história, mesmo em registros passados de gerações de surdos para outras, os quais muitas vezes eram ocultos, pelo medo das repreensões sofridas pela proibição da mesma, sobretudo nos espaços públicos. A maioria foi repassada de geração em geração de surdos através dos tempos na forma da SINALIDADE. O termo SINALIDADE foi por mim pensado para ser usado neste projeto de pesquisa a partir do termo ORALIDADE, pois, de acordo com Marcuschi (2010, pag.25), “a oralidade seria uma prática social interativa para fins comunicativos que se apresenta sob variadas formas ou gêneros textuais fundados na realidade sonora". Assim como os sujeitos ouvintes estão para a oralidade, os surdos estão para a SINALIDADE. Portanto, a Sinalidade é uma prática social interativa na modalidade visual para fins comunicativos sociais que também se apresenta sob variadas formas ou gêneros textuais fundados na modalidade visual. ${ }^{14}$

Para a Língua de Sinais, foi (ainda é, de acordo com o pensamento de pessoas leigas a respeito da Língua de Sinais ou da pessoa surda) muito difícil obter a aceitação e o reconhecimento de seu status linguístico, mesmo na atualidade em que muitos avanços conceptuais e ideológicos já foram alcançados.

Transcrevo a seguir, a tradução de Desloges no qual ele defende sobre que seria um erro nos retratar como incapazes de obter uma comunicação, uma linguagem. É através da percepção de si que Desloges pode nos afirmar que a Língua de Sinais tem a capacidade de linguagem, assim como todas as outras línguas, e que também possuem linguagem. Como diz

\footnotetext{
${ }^{14}$ Este termo também é usado na dissertação de mestrado de outro surdo mestre e atualmente é recém-doutor, Cláudio Henrique Nunes Mourão, conhecido como Cacau Mourão, em sua dissertação de mestrado em Educação: 〈https://www.lume.ufrgs.br/bitstream/handle/10183/32311/000785443.pdf?sequence=1〉.
} 
Merleau-Ponty (2015, pag. 22) “ nossa percepção cotidiana não é de um mosaico de qualidades, mas a de um conjunto de objetos distintos" que nos traz o saber das nossas percepções, que nos determinam como resultados das experiências atuais para viver na sociedade cultural.

\begin{abstract}
Há surdos-mudos de nascença, operários em Paris, que não sabem nem ler nem escrever e que nunca assistiram às aulas do Abade De L'Epée, os quais são tão bem instruídos de sua religião unicamente por meio dos sinais, que foram considerados dignos da admissão aos Sacramentos da Igreja, até mesmo à Eucaristia e ao Casamento. Não há nenhum acontecimento em Paris, na França ou nas quatro partes do mundo, que não seja assunto de nossas conversas. Nós nos expressamos sobre todos os assuntos com tanta ordem, precisão e rapidez quanto se gozássemos da faculdade de falar e de ouvir.

Seria um erro grosseiro nosso olhar como espécies de autômatos destinados a vegetar no mundo. A natureza não foi tão madrasta conosco como se julga geralmente: ela sempre supre um sentido do que falta aos outros. A privação da audição nos torna em geral menos distraídos. Nossas ideias concentradas, por assim dizer, em nós mesmos nos levam necessariamente à meditação e à reflexão. A linguagem que utilizamos entre nós, sendo tão somente uma imagem fiel dos objetos que queremos expressar, é singularmente própria a nos dar justeza nas ideias, a espalhar nosso entendimento pelo hábito de observar e analisar incessantemente. Essa linguagem é viva: o sentimento está nela retratado, a imaginação nela se desenvolve. Nenhuma outra é mais apropriada a carregar na alma grandes e fortes emoções (DESLOGES, 1779, pag. 16-17. Tradução Loro).
\end{abstract}

\title{
1.4 Prestígio da escrita segundo Saussure
}

Fala e escrita são dois sistemas distintos de signos; a única razão de ser do segundo é representar o primeiro. Muitas vezes, pessoas se confundem que a escrita seja a grafia fiel da fala. Minha mãe relata o estranho momento em que eu passei a ler os lábios: "aprendeu sozinha a ler os lábios das pessoas, a partir do primeiro momento que ela parou de ouvir, ela começou a ler os lábios das pessoas, nem mesmo, nós pais percebemos". Seria esta, a leitura labial, algo a ver com grafia da escrita?

Segundo Saussure, os homens confundem a língua com a grafia; a língua é adquirida antes mesmo dos reconhecimentos gráficos da escrita. É importante ressaltar que a aquisição da língua é de fundamental importância para o desenvolvimento social, psicológico e cognitivo. Mas a escrita não é a grafia fiel da língua, ela é apenas uma representação da língua de modo que o homem seja capaz de reconhecer os símbolos e se expressar através deles.

Para Saussure, a "palavra escrita se mistura tão intimamente com a palavra falada", ou seja, a escrita ainda está no pensamento das pessoas como a forma representativa do pensamento como signo que é formado pela combinação do significante com o significado, portanto, na formação da criança surda está em primeiro lugar dar a oportunidade para a 
mesma adquirir sua língua, mesmo que esta seja totalmente visual, pois a leitura labial para nós surdos é uma das formas visuais da vocalidade. Mas a língua de sinais também é uma das formas visuais que não há prejuízo nenhum de adquirir uma linguagem e também a escrita.

$\mathrm{Na}$ sociedade atual tenho observado muita pressão sobre a criança e o adulto surdo sobre o "dever" de saber e ler na língua portuguesa escrita. Ninguém até o momento se preocupou em respeitar a primeira língua da criança surda, neste caso a LIBRAS. O que tenho observado é que ainda há uma discriminação da sociedade sobre a LIBRAS, principalmente nas famílias onde a criança surda é fillho(a) de pais ouvintes. A família realiza uma "grande luta" para que a criança surda aprenda a "falar oralmente", "ouvir bem" submetendo-lhe implantes cocleares ou simplesmente aparelhos auditivos, a fim de dar "um pouco" de alegria aos pais ouvintes. Tenho observado muito isso através de minha vivência nas visitas às escolas que realizava há muito tempo e também ainda hoje. Ainda existe a repreensão sobre a LIBRAS. Ou seja, ainda estamos vivendo o fantasma do Congresso de Milão.

Minha experiência de pessoa surda sobre o olhar da escrita em relação ao surdo vem depois da descoberta da Libras e da Comunidade Surda. Muitas vezes, perguntei-me sobre a razão de eu ser diferente dos surdos, pois tinha uma prática baseada apenas na escrita. Por que a comunidade ouvinte vê a escrita do surdo de forma tão diferente? Os surdos já se constituem uma comunidade, portanto possuem cultura e língua diferentes daquelas da comunidade ouvinte. A resistência da pessoa surda brasileira que luta pelo reconhecimento da Libras como língua vem de uma luta muito antiga. Além disso, em relação a sua escrita, a pessoa surda ainda sofre com as discriminações relacionadas à sua incapacidade de se expressar na escrita da língua dos ouvintes. Seria mesmo incapacidade de expressão escrita?

Refletindo a partir da leitura de Foucault, que faz formulações sobre o quadro $A s$ Meninas, de Velásquez, detenho-me numa cena em que as visões entre os dois mundos (ouvintes e surdos) se assemelhem a essa visão sobre a obra:

No momento em que colocam o espectador no campo de seu olhar, os olhos do pintor captam-no, constrangem-no a entrar no quadro, designam-lhe um lugar ao mesmo tempo privilegiado e obrigatório, apropriam-se de sua luminosa e visível espécie e a projetam sobre a superfície inacessível da tela virada. Ele vê sua invisibilidade tornada visível ao pintor e transposta em imagem definitivamente invisível a ele próprio. (FOUCAULT, 2000, p. 05) 
Muitas vezes, as pessoas ouvintes lançam um olhar "que não vê" sobre a pessoa surda; ocorre uma invisibilidade acerca da subjetividade surda, pois ainda há um mundo separatista entre surdos e ouvintes. A visão sobre o corpo da pessoa surda é que, no jogo nas imagens de uns sobre os outros, os ouvintes acham-se no direito de ter poder sobre ela, como algo patológico a ser corrigido pelas visibilidades perfecionistas. Eu, como pessoa com surdez, vivo em um mundo com limitações auditivas e vejo a Língua Oral como algo desconhecido, somente compreensível minimamente graças à leitura labial, uma modalidade visual pela qual se reconhecem os códigos vocais. A modalidade visual é a minha única capacidade de assimilação, vivo aquém das fronteiras do mundo da modalidade vocal.

Como se reconhece a modalidade visual? É possível entender a escrita como algo diferente da oralidade, da acústica física? Saussure (2013. p. 106 ) ao conceituar o signo linguístico, afirma que as palavras são verdadeiras "imagens acústicas", portanto elas só fazem sentido quando forem tratadas como "imagens", captadas por um cérebro capaz de assimilar as ações em relação aos fatos concretos e visuais:

\footnotetext{
Os termos implicados no signo linguístico são psíquicos e estão unidos, em nosso cérebro, por um vínculo de associação. Insistamos nesse ponto. O signo linguístico une não uma coisa e uma palavra, mas um conceito e uma imagem acústica. Esta não é o som material, coisa puramente física, mas a impressão (empreinte) psíquica desse som, a representação que dele nos dá o testemunho de nossos sentidos; tal imagem é sensorial e, se chegamos a chamá-la "material", é somente nesse sentido, e por oposição ao outro termo da associação, o conceito, geralmente mais abstrato. $\mathrm{O}$ caráter psíquico de nossas imagens acústicas aparece claramente quando observamos nossa própria linguagem. (SAUSSURE, 2013. p. 106)
}

Diante dessas palavras, podemos refletir sobre a funcionalidade da escrita, sobre o fato de ser tão dominante na nossa sociedade, pois se trata de um espelho da mente humana. O que me faz refletir sobre a escrita é que os ouvintes pensam que a escrita "é o espelho da língua". Poderia dizer o mesmo para mim, como pessoa surda, que cada imagem refletida no espelho, seja como se a escrita seja a imagem da língua oral. O mesmo posso dizer que sobre nós, surdos: as palavras que escrevemossão a imagem refletida do espelho psíquico com que nos comunicamos. Por que falo de espelho psíquico? Vem de uma reflexão de Foucault, em que analisa o quadro "Las Meninas" e diz:

É preciso reconhecer que essa indiferença só se iguala à do espelho. Na pintura holandesa, era tradição que os espelhos desempenhassem um papel de reduplicação: repetiam o que era dado a uma primeira vez no quadro, mas no interior de um espaço irreal, modificado, estreitado, recurvo"(FOUCAULT, 2000. p. 08) 
Para mim, quando aprendi a escrita, sabia que era algo espelhado da imagem da escrita oral dos ouvintes. Imaginei dessa forma, sempre a tentar interpretar cada imagem. Dessa forma pude "construir" a ponte entre os mundos ouvinte e surdo. As frases escritas passaram a fazer sentido depois que aprendi a Libras aos 25 anos. Demorei 18 anos para assimilar as frases, para saber interpretar todo sentido e razão das frases. Por que? Pelo simples fato de que tudo é Imagem para mim: até mesmo a ausência de sons é para mim uma imagem, tudo é representado por ações que servem como um discurso, uma interpretação da linguagem sobre os signos linguísticos.

Aprofundarei este conteúdo baseado no capitulo 3, onde abordarei as experiencias vividas de como eu via a escrita. 
CAPÍTULO 2

CONSIDERAÇÕES TEÓRICAS 
Neste capítulo, busquei teorias em que procurava relacionar os estudos científicos e filosóficos sobre as pessoas surdas, sua cultura e identidade, e ainda buscar a refletir sobre minha visão de mundo de pessoa surda sobre as teorias cientificas nas áreas de linguística, semiótica, a fenomenologia e etnografia. Estas abordagens que usarei durante a análise, está focada na linha de pesquisa da Análise do Discurso, onde buscamos analisar baseado três pilares que sustenta esta linha: a Língua, o Sujeito e a História. Busquei a etnografia para trabalhar sobre o que vem a ser a comunidade surda, como é vista tanto pelo mundo ouvinte como pelo mundo surdo. Para este caso de estudo, a forma que uso a etnografia é para representar a cultura, identidade e língua da comunidade surda como base para compreender a pesquisa: a experiencia das fronteiras entre mundo surdo e mundo ouvinte. Neste caso, estou contemplando o Sujeito, a História e a Língua do Surdo.

Já a fenomenologia é buscada para explanar a essência do fenômeno de Ser Surda, em que busco através de meu olhar, a minha interpretação sobre o mundo externo em que vejo sobre as sub conjugações sobre a pessoa surda e sua cultura e identidade. A fenomenologia hermenêutica dá conta de seu objeto de pesquisa, é a forma de ser/existir/perceber e conceber o mundo, sobre a linguagem. Neste caso, a minha experiencia de pessoa surda, de como eu vejo a escrita de como é vista a escrita das diferentes formas de linguagem, é que busco a compreensão desta linguagem.

Durante os estudos, me questionei muitas vezes se eu poderia falar de minha experiência de vida como pessoa surda mesmo sendo oralizada, pois sempre considerei a LIBRAS (Língua Brasileira de Sinais) como uma experiência de quebra das fronteiras entre o mundo do ouvinte e surdo. Por que falo de fronteira? Tenho observado que há falta de informação por parte de pessoas que desconhecem o fenômeno de ser surdo, que consiste em um fenômeno de experiência de comunicação estritamente visual. As fronteiras são criadas por ideologias mantidas ao longo do tempo que, devido ao fato de ver um corpo diferente, produzem nele o sentido de imperfeição.

As reflexões de Foucault (2000) sobre os acontecimentos da rejeição do Surdo apontam que este se deve ao fato da sociedade ainda ter a visão do corpo perfeito, segundo os ideais gregos; ainda se pensa que o surdo deve ter a imagem refletida dos ouvintes como um espelho: “É preciso reconhecer que essa indiferença só se iguala à do espelho". Ou seja, ouvintistas querem que surdos sejam o espelho deles, que sejam cópias fiéis, corpos idênticos e falas idênticas a eles mesmos. Por outro lado, o discurso médico também reflete nas decisões sobre a educação dos surdos e também nos conceitos de comunicação e na aceitação da Língua de Sinais Brasileira - LIBRAS. 
Da mesma forma, a escrita do surdo em Língua Portuguesa é retratada como incompreensível, pois as tentativas de fazer o surdo aprender a ler e a escrever são práticas sempre focadas nos princípios oralistas. Não tenho dúvida dessa questão pois, muitas vezes, minhas leituras e escritas, nos vários períodos escolares, foram bastante rejeitadas, apesar de minhas inúmeras tentativas de agradar os ouvintes e meus esforços para ser aprovada nas várias disciplinas curriculares, pelo menos dentro das médias, para conseguir sobreviver aos regimes da oralidade e também ser aceita na sociedade ouvinte. Eu tinha uma visão de que eu era sozinha e me considerava a única surda na cidade, ou até mesmo no país. Eu era cobrada constantemente pela perfeição de minha escrita, uma escrita de acordo com os princípios da oralidade.

Muitas vezes tornei-me copista a fim de agradar os professores, pois eram comuns exercícios de cópias de palavras, de frases, até de textos inteiros. Todas essas minhas experiências são também retratadas pelos meus amigos surdos, principalmente aqueles que são Surdos Puros, que possuem linguagem pré-linguística ${ }^{15}$, por isso sofrem uma rejeição mais forte do que a retratada no relato de minha vivência. Minha língua, minha fala e meu conhecimento de linguagem de mundo, tudo é vivenciado na Imagem. Minha vida foi totalmente construída a partir da Imagem das ações, da Imagem dos fatos e das tentativas de interpretar através das Imagens. Este é o conceito fenomenológico e etnográfico do ser surdo que mobilizarei durante a dissertação.

\subsection{Conceitos de Pesquisa:}

\subsubsection{Etnografia sobre Pessoas Surdas}

A etnografia é uma área das Ciências Sociais que surgiu na Antropologia Cultural e Sociologia Qualitativa, um aparato teórico-metodológico desenvolvido pelos antropólogos para estudar a cultura e a sociedade. Etimologicamente, etnografia significa "descrição cultural” (práticas, hábitos, costumes, crenças, valores, linguagens e significados) de um grupo social. A chamada "ciência das etnias" tem, como base de seu significado, ethos, do grego (cultura) + graphe (escrita). É uma pesquisa dentro da abordagem qualitativa e empírica

\footnotetext{
${ }^{15}$ Surdez pré-linguística são aqueles Surdos que já nasceram surdos e desenvolvem a fala sinalizada a partir das experiências visuais. Já a surdez pós-linguística é a surdez adquirida causada após um fato ocorrido no período perinatal ou pós-natal. Pode ocorrer através de doenças adquiridas que causam a surdez durante o período da aquisição da linguagem ou língua após o nascimento como pessoa ouvinte.
} 
e que resultou em abordagens pluralistas, pois é um campo ampliado em muitas áreas como o estudo de grupos e o desenvolvimento da cultura (ANDRÉ, 1995 e CRESWELL, 2014).

Apesar de estar bastante relacionado às ciências sociais, no campo da educação esse método começa a ser utilizado como meio de conhecimento da cultura da sociedade, a fim de contribuir para estudos de contextos educacionais e sociais. É um tipo de pesquisa que se propõe a compreender e a interpretar os fenômenos educacionais que acontecem no contexto escolar (ESTEBAN, 2010).

Já na Análise do Discurso, a etnografia contribui para uma compreensão descritiva da cultura da sociedade, já que na $\mathrm{AD}$ não se vê a Língua como sistema, mas sim a Língua como seu uso no mundo, portanto a língua na cultura e na identidade de um povo. Dessa forma, é possível que a etnografia contribui para compartilhar uma cultura do comportamento, da crença e da linguagem da língua em uso.

Consequentemente, o discurso é o lugar em que se pode observar essa relação entre língua e ideologia, dentro da etnografia. Assim sendo, a etnografia descreve e interpreta padrões compartilhados e apreendidos de valores, comportamentos, crenças e linguagem de um grupo que compartilha a mesma cultura (CRESWELL, 2014).

Como pessoa surda, posso contribuir para a descrição da cultura e da língua de sinais da comunidade surda que compartilha um vasto conhecimento, estruturas e linguagens descritas, principalmente na modalidade visual, através dos discursos escritos por pessoas surdas, representados pelos membros dessa comunidade que, por muito tempo, vivenciaram dramas de rejeição, de discriminação e de mutilação em razão da diferença de corpos considerados deficientes.

Lane (1992) retrata e nos exemplifica muito bem a rejeição do surdo pelo ouvinte. O surdo é marcado pela humilhação devido à condição da falta de audição e também ao egocentrismo da falta de informação. Pessoas leigas têm pensamentos incorretos ao imaginar o mundo do surdo como um mundo sem sons, imaginam a surdez como um mundo de ecos vazios e solitários, imaginam que o pensamento de uma pessoa surda é como um vazio de mensagens e linguagem. São ideias e conceitos de pessoas baseados no egocentrismo e no ouvintismo. Ouvintismo é a condição da pessoa que não aceita a condição do surdo como pessoa possuidora de cognição diferente das pessoas ouvintes, considerando a medicalização como única forma de consertar e tentar "curar" as pessoas surdas. A medicalização é uma concepção dos médicos otorrinos, dos terapeutas da fala e dos comerciantes de aparelhos auditivos. Tenho observado também que a medicalização da pessoa surda se tornou uma concorrência do mercado internacional por meio das vendas de produtos para "ouvir e falar 
bem". Como diz Lane (1992, pag. 39) sobre as humilhações e discriminações dos ouvintes sobre os surdos:

\begin{abstract}
A medicalização da comunidade dos surdos, caracterizada por uma longa história de lutas entre os surdos e ouvintes que afirmam servi-los, pelo direito em definir um problema e colocá-lo em determinado domínio social e não noutro - para analisá-lo como uma questão da medicina, educação, reabilitação, religião, política - é feita de acordo com a opinião dos ouvintes em virtude de estes serem mais fortes. Nos finais dos séculos passados, os professores ouvintes assumiram o controlo das escolas para crianças surdas e acabaram com a ASL e os professores surdos. Com as alterações culturais, o aluno surdo era agora um estranho. A linguagem oral e a terapia da fala realizadas na sala de aula não conseguiram integrá-lo no grupo, ao mesmo tempo que o processo de educação falhava, confirmando-se deste modo a incapacidade da criança. [...] Ao retirar a criança surda do seu mundo surdo, ao bloquear a sua comunicação com seus pais, colegas e professores, os especialistas incapacitaram a criança surda de um modo nunca antes visto na América.[....] O modelo da enfermidade tornou-se mais plausível quando aplicado aos jovens surdos; com a integração acadêmica, a consideração da surdez enquanto problema, cultural ganhou mais terreno ao mesmo tempo que o "milagre" da tecnologia respeitante aos implantes cocleares em crianças progrediu. Este último avanço ilustra um princípio da opressão mencionado por Jean-Paul Sartre: "os opressores produzem e mantém por força os males que, aos olhos, tornam, cada vez mais, o oprimido naquilo que deveria ser para merecer seu destino".( LANE, 1992, pag. 39)
\end{abstract}

É ainda mais opressor o surdo ser rotulado como portador de enfermidade, doente, incapaz de pronunciar uma palavra ou escrever em português. Mais uma vez, Lane (1992) nos mostra a face de uma realidade, mesmo que há muito tempo atrás, que se mantém até os dias atuais: a realidade sofrida pela comunidade surda em que as línguas de sinais e a subjetividade Ser Surdo é retratado como doença, enfermidade, gestos e mímico.

\begin{abstract}
Após ter avaliado as suas capacidades e de a ter rotulado, o audiologista entrega a educadores especiais a criança surda, mas saudável, que, entretanto, se tornou numa criança doente; a criança agora é rotulada com um modelo de enfermidade, de doença, tendo adquirido uma segunda personalidade, a qual está descrita no dossiê de acompanhamento. Geralmente a tarefa do educador não é educar, é encontrar um tratamento educacional para aquilo que o otologista e audiologista não conseguiram tratar: o insucesso da criança em aprender inglês. Tem sido identificada uma diferença; mas está agora a começar uma intensa campanha para acabar com ela. (LANE, 1992, pag. 39).
\end{abstract}

O autor relata o caso de uma criança surda americana, após tentativas de fazê-la falar oralmente e ouvir:

\title{
2.2 Fenomenologia das pessoas surdas
}

Minha escolha pela abordagem fenomenológica e etnográfica nesta pesquisa em $\mathrm{AD}$ se deu pelos seguintes motivos: a fenomenologia descreve a essência de um fenômeno vivenciado. Minha escolha deste enfoque se deve às circunstâncias e experiências de vivência 
do fenômeno de ser surda. Minha vida de pessoa surda foi vivenciar um fenômeno de fraca compreensão na comunicação, de falta de interação social, de estranhamento em relação à língua no mundo entre ouvintes e surdos. A fenomenologia é a corrente filosófica do pensamento interpretativo através das memórias da experiência vivida. Vem totalmente ao encontro do que eu pretendo desenvolver neste trabalho.

Voltar à experiência pré-racional, à experiência vivida não se refere à sensações passivas, mas à percepção que, junto à interpretação, orienta objetivos, valores e significados, uma interpretação a qual Husserl denominou de "intencionalidade"; é o lema que representa a essência do movimento fenomenológico (ESTEBAN, 2010).

Edmund Husserl (1859-1938), o fundador da fenomenologia, considerava esta como uma filosofia, uma abordagem e um método. É um estudo das estruturas da consciência e que requer a investigação sobre o conteúdo da mente, cujos métodos de reflexão consistem nos atos de recordar, desejar e perceber o conteúdo abstrato como significado. Todo significado dos aspectos nos levam a uma direcionalidade a qual Husserl chama de intencionalidade, que é a essência da consciência. A língua é a essência da comunicação, é o significado abstrato da mente.

Husserl distinguiu duas correntes ou enfoques na fenomenologia:

- Fenomenologia Eidética, que é epistemológica e enfatiza o retorno à intuição para descrever e explanar a experiência vivida, dentro da consciência;

- Fenomenologia Hermenêutica, que é ontológica, consiste no enfoque interpretativo por meio da forma de existir/ser/estar no mundo através da dimensão histórica e sociocultural vivenciada e se expressa por linguagem (ESTEBAN, 2010).

A fenomenologia tem como foco a abordagem da intencionalidade e experiências fenomênicas determinadas por um grupo social, por uma comunidade linguística. No caso desta pesquisa, será abordado o grupo social e linguístico dos surdos por meio da experiência vivida por mim como pessoa surda, oralizada e sinalizada. O estudo fenomenológico descreve o significado comum para vários indivíduos das suas experiências, de um conceito ou fenômeno. O propósito básico da fenomenologia é reduzir as experiências individuais de um fenômeno a uma descrição da essência universal. Como diz Merleau-Ponty (1999, pag. 0102):

A fenomenologia é o estudo das essências, e todos os problemas, segundo ela, resumem-se em definir essências: a essência da percepção, a essência da consciência. Mas a fenomenologia é também uma filosofia que repõe as essências na 
existência, e não pensa que se possa compreender o homem e o mundo de outra maneira senão a partir de sua "facticidade". É uma filosofia transcendental que coloca em suspenso, para compreendê-las, as afirmações da atitude natural, mas é também uma filosofia para a qual o mundo já está sempre "ali", antes da reflexão, como uma presença inalienável, e cujo esforço todo consiste em reencontrar este contato ingênuo com o mundo, para dar-lhe enfim um estatuto filosófico. É a ambição de uma filosofia que seja uma ciência "exata", mas é também um relato do espaço, do tempo, do mundo "vividos". É a tentativa de uma descrição direta de nossa experiência tal como ela é, e sem nenhuma deferência à sua gênese psicológica e às explicações causais que o cientista, o historiador ou o sociólogo dela possam fornecer. (MERLEAU-PONTY, 1999, pag. 01-02)

É desta maneira que pretendo me questionar sobre a minha vivência entre os mundos ouvinte e surdo, a vivência de ter adquirido a comunicação, a vivência de ter adquirido a escrita e a vivência de ser surda e ser aceita pela comunidade tanto ouvinte como surda. Esses questionamentos levaram-me à Língua de Sinais e sua valorização, enquanto corpus, pois foi esta língua que adquiri mesmo em idade avançada que me possibilitou a quebra das fronteiras entre as comunicações surdas e ouvintes, incluindo neste corpus os relatos de experiências de pessoas envolvidas na minha formação intelectual, comunicativa e cultural.

Os preceitos teóricos da Fenomenologia Hermenêutica são os indicados para a análise do corpus (relatos), pois é uma pesquisa orientada para a experiência vivida e para a interpretação dos "textos" da vida. Não somente uma descrição, mas também um processo interpretativo no qual o pesquisador faz, mais que uma interpretação, uma "mediação" entre os diferentes significados. Novos pesquisadores que abraçam essa ideia iniciam seus projetos descrevendo experiências próprias em relação ao fenômeno investigado, colocando entre parênteses as suas visões antes de realizar o trabalho com o corpus composto pelas experiências alheias, mantendo uma forte relação com o tópico de investigação.

Já na outra abordagem da Fenomenologia - Transcendental ou Empírica -, que consiste na identificação de um fenômeno e no estudo das próprias experiências e dos dados coletados por meio de diversas pessoas que experimentaram o fenômeno, foca mais na descrição das experiências dos participantes e menos na sua interpretação, pois faz combinação com bases teóricas científicas. Tal abordagem desenvolve uma descrição textual (“o quê?”) da experiência das pessoas e estrutural (“como?”) para então transmitir a essência geral da experiência.

Este trabalho de pesquisa terá abordagem hermenêutica, pois estudarei minha própria experiência de ser surda, como adquiri minha língua, minha linguagem, minha escrita e como adquiri a LIBRAS como o último fenômeno da essência da completa comunicação entre os mundos ouvinte e surdo quebrando as fronteiras da comunicação (CRESWELL, 2014). O 
Sujeito Surdo, a história da comunidade surda, a Língua de Sinais e a linguagem, dentro das perspectivas metodológicas etnográficas e fenomenológicas, serão tomados como objeto de estudo segundo os preceitos teóricos da Análise de Discurso buscando compreender a língua não só como estrutura, mas um acontecimento, uma experiência viva da interação social, principalmente da pessoa surda.

Nós, da comunidade surda, lutamos pela preservação da Língua de Sinais como a língua mediadora da relação entre os mundos ouvinte e surdo, a ponte entre esses dois mundos de diferentes modalidades. Não se trata de métodos de preservação, mas sim da história do conhecimento da essência da relação linguagem/pensamento/mundo das pessoas surdas e de "revelar os princípios e as consequências de uma transformação autônoma que está em vias de se realizar no domínio do saber histórico” (FOUCAULT, 2008).

\subsection{0 discurso Surdo}

Para complementar a análise da pesquisa, foi constituído o corpus com os discursos surdos falam de sua cultura e identidade e poder surdo, assim como defendo por ser responsável pela minha evolução existencial completa e por minha realização como ser social. Além desses, também constituem o corpus relatos de experiência de pessoas que se envolveram na minha formação intelectual e social como minha mãe e meu pai, minha professora do primeiro ano do ensino fundamental (antigo $1^{\circ} \mathrm{Grau}$ ).

O corpus define-se por Linguística de Corpus, que:

\footnotetext{
Ocupa-se da coleta e exploração de corpora, ou conjuntos de dados linguísticos textuais que foram coletados criteriosamente com o propósito de servirem para a pesquisa de uma língua ou variedade linguística. Como tal, dedica-se à exploração da linguagem através de evidências empíricas. (SARDINHA, 2000, pag. 325)
}

Consegui coletar muito pouco corpus de pessoas surdas que defendem a identidade e cultura surda e corpo surdo ao longo do tempo. Confesso que é muito difícil encontrar corpus, principalmente livros, pergaminhos, pinturas realizadas pelas pessoas surdas. No caso das pinturas, há uma ocultação sobre a autoria e só é possível confirmar a autentidade da obra realizada por um surdo se contém fatos históricos registrados pela comunidade surda, através das associações ou também registros passados de geração para geração. Um exemplo de pintura realizada por surdos é o caso do pintor famoso Goya (1746-1828), que retrata as expressões faciais em muitos de seus quadros. As expressões faciais são consideradas marcas 
linguísticas que constitui a gramática da língua de sinais (FERREIRA, 2010). As expressões faciais e corporais são para estabelecer tipos de frases, assim como as entonações na língua portuguesa como, por exemplo: a forma afirmativa, exclamativa, interrogativa, negativa ou imperativa; precisa-se estar atento às expressões faciais e corporais que são feitas simultaneamente com certos sinais ou com toda a frase.

Não pode ser considerada como simples linguagem corporal, mas sim a linguagem não-verbal. Quando Goya ficou surdo em $1792^{16}$, suas pinturas sofreram uma verdadeira mudança, tornando-as mais expressivas, passando a captar maior observação dos fatos e percepções corporais.

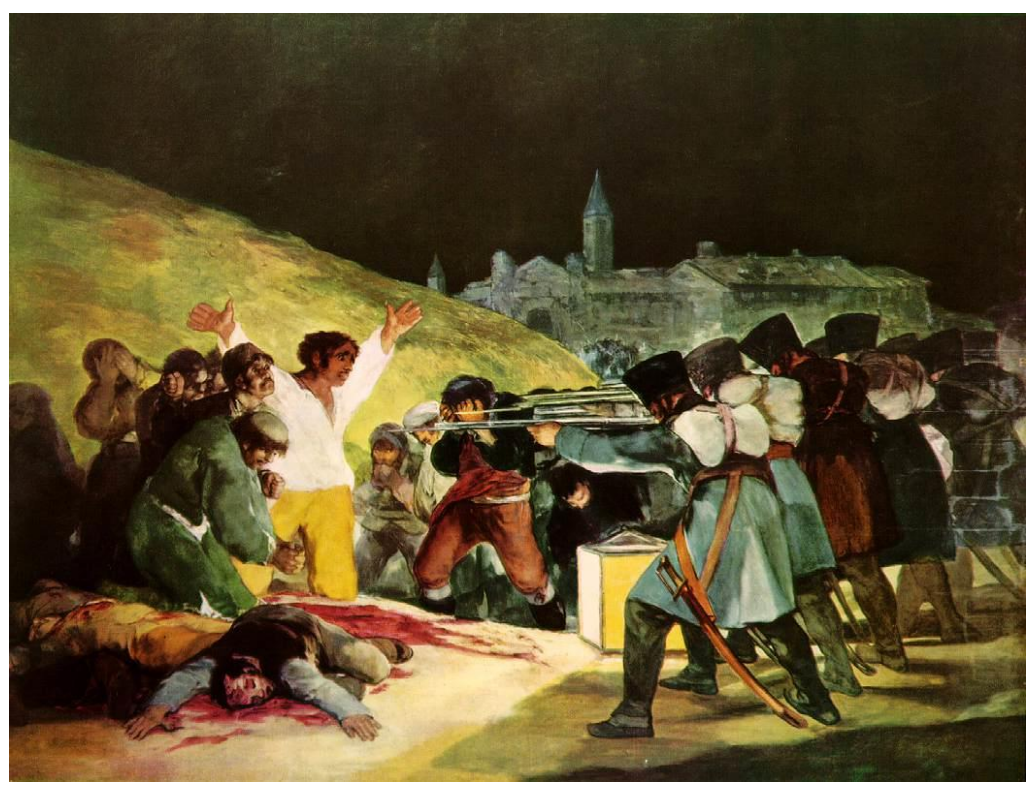

Figura 1 - Três de Maio de 1808 em Madrid - óleo sobre tela- 1814- Fonte: <http://ww1.prweb.com/prfiles/2013/04/30/10686426/gI_69047_goya-los-fusilamientos-del-3-de-mayo2.jpg data $25 / 10 / 2016>$.

Pierre Desloges foi um importante surdo francês, jacobino que defendeu a língua de sinais e também o método empregado por L'pée em defesa dos surdos sobre o uso da Língua de Sinais como meios de comunicação e educação. O Contexto da história escrita por Desloges se realiza num discurso de poder sobre a necessidade da defesa de uma cultura e língua. . Único livro escrito pelo próprio Desloges, em 1779 faz críticas à Duchamps, que foi um outro defensor do oralismo em que publica contra as Línguas de Sinais e o método empregado por L'pée.. É muito raro encontrar livros ou fragmentos registrados na história, principalmente escritos ou pinturas. 


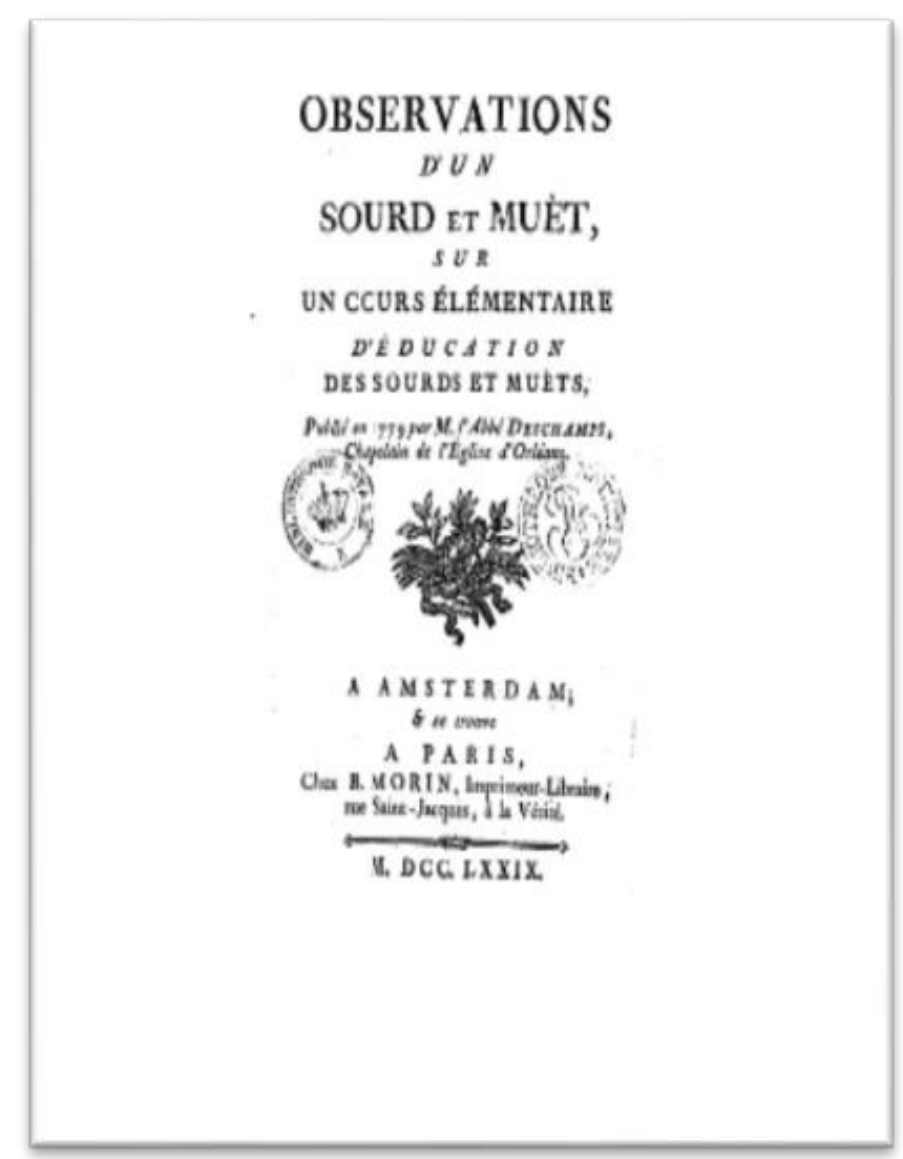

Figura 2- capa do Livro de Pierre Desloges (surdo) Observações feitas da Língua de Sinais Francesa e o trabalho do Abade L'Eppé

Esse livro fez parte de minhas leituras sobre o poder surdo, me identificou muito, pois Desloges foi um surdo que teve contato com a Língua de Sinais somente após ser adulto e o acesso à Língua de Sinais lhe descortinou o acesso ao mundo dos ouvintes e o sentido da vida. O mesmo ocorreu comigo, só pude aprender a LIBRAS muito tarde, mas meu mundo descortinou e pude compreender o sentido da vida e o significado das comunicações. Transcrevo um trecho de Desloges sobre a importância da Língua de Sinais:

Seria um erro grosseiro nos olhar como espécies de autômatos destinados a vegetar no mundo. A natureza não foi tão madrasta conosco como se julga geralmente: ela sempre supre um sentido do que falta aos outros. A privação da audição nos torna em geral menos distraídos. Nossas ideias concentradas, por assim dizer, em nós mesmos nos levam necessariamente à meditação e à reflexão. A linguagem que utilizamos entre nós, sendo tão somente uma imagem fiel dos objetos que queremos expressar, é singularmente própria a nos dar justeza nas ideias, a espalhar nosso entendimento pelo hábito de observar e analisar incessantemente. Essa linguagem é viva: o sentimento está nela retratado, a imaginação nela se desenvolve. Nenhuma outra é mais apropriada a carregar na alma grandes e fortes emoções. (DESLOGES, 1779, pag. 16-17. Tradução Loro) 
No Brasil, em tempos atuais, também temos publicações dos surdos em defesa da comunidade surda A comunidade surda sempre teve anseio sobre a preservação da sua língua e também da sua cultura. O corpus da professora Mestre Shirley Vilhava, que também publica um livro de relatos de experiência do fenômeno de ser surda e também sobre a LIBRAS, é fortemente registrado no livro $O$ Despertar do Silêncio:

\begin{abstract}
Eu tive um renascer ao estar na comunidade surda, aquele sentimento de estar só no mundo acabou e o medo das pessoas foi diminuindo e assim através da Língua de Sinais eu comecei a entender os significados dos sentimentos, das coisas, das pessoas, das ações e muito mais das palavras. Eu comecei a viver realmente como as demais pessoas e entender o porquê de minha existência, tudo ficou melhor quando eu descobri e tive a compreensão do que meu padrasto havia me ensinado sobre encontrar um mundo melhor, procurando ser cada dia melhor e dizia ainda que "Quando eu soubesse viver em paz com a intimidade de minha alma eu poderia compartilhar com outras pessoas", verdade, isso eu só encontrei quando entrei para o mundo totalmente visual-espacial na comunidade surda. (VILHALVA, 2004, pag. 37)
\end{abstract}

Atualmente há surdos realizando seus estudos em diversas Faculdades e muitos também já ingressaram no mestrado e doutorado dedicando suas pesquisas em defesa da identidade, cultura e valorização do discurso do poder surdo. Este fenômeno é explanado por Marques (2008) que relata sobre uma pesquisa ontológica sobre o Ser Surdo fundamentada no próprio corpo; uma reflexão sobre as pessoas surdas antes de destacar seus aspectos culturais. Tais aspectos são sempre influenciados pela linguagem visual, tornando-esta como requisitos da comunicação entre os mundos ouvintes e surdos.

\begin{abstract}
A investigação do que proporciona a experiência de ser surdo me parece mais sustentável do que as "representações" que ela produz; o que lhes confere a possibilidade de construir estas experiências só podemos descrevê-las a partir de uma observação do corpo, a "experiência visual" passa a ser apenas um entre os vários aspectos e, mesmo assim, ela mesma se desprende em diversas partes a serem investigadas. Pois “(...) só posso compreender a função do corpo vivo realizando-a eu mesmo e na medida em que sou um corpo que se levanta em direção ao mundo". (MARQUES, 2008, pag. 65)
\end{abstract}

Em todos os momentos, o surdo como sujeito histórico, social e linguístico se destacará em defesa de sua língua e sua cultura visual devido ao seu aspecto de produzir sentidos para a compreensão da existência social e linguística nas fronteiras dos ouvintes e surdos. O que nos falta é a aceitação de suas palavras discursivas, apesar do ouvintismo ainda existir de fato, devido à influência do "corpo dócil" enraizado na sociedade, segundo Foucault (1999, pag.119), no qual o corpo humano entra numa maquinaria de poder para enquadrar e definir sobre o domínio do corpo, e que a disciplina fabrica os mecanismos dos corpos 
submissos. O mesmo ocorrerá quando relatar a experiência do meu fenômeno de ser surda, antes mesmo do surgimento da LIBRAS e também da cultura e identidade surda como descortinamento da vivência adquirida.

\title{
2.4 Reflexões de Benveniste sobre a Língua de Sinais
}

\begin{abstract}
Quando abrimos os olhos para a importância do risco e para as consequências que os atuais debates podem ter também para as outras disciplinas, somos tentados a pensar que as discussões sobre as questões do método em linguística poderiam ser apenas o prelúdio de uma revisão que englobaria, finalmente, todas as ciências do homem (BENVENISTE, 1995, pag. 04)
\end{abstract}

Gostaria de englobar nestas considerações teóricas a respeito da Língua Brasileira de Sinais, LIBRAS, os preceitos de Benveniste (1995, pag. 04). A título de ilustração, apresentarei algumas pesquisas sobre as Línguas de Sinais enfocando aspectos linguísticos da Língua de Sinais, sobretudo suas relações com as estruturas das línguas orais. A estudiosa Lucinda Ferreira corrobora essa ideia ao afirmar que a Língua de Sinais não poderia ficar fora dos estudos linguísticos por ser uma faculdade de linguagem das pessoas:

\footnotetext{
O canal visuo-espacial pode não ser o canal preferido pela maioria dos seres humanos para o desenvolvimento da linguagem, posto que a maioria das línguas naturais são orais-auditivas, porém é uma alternativa que revela de imediato a força e a importância da manifestação da faculdade de linguagem nas pessoas.

Assim sendo, se a linguística busca o conhecimento dessa faculdade de linguagem, não poderá ignorar as línguas de sinais em sua investigação, pois só assim poder-seá encontrar os verdadeiros universais linguísticos e compará-los com especificidades acidentais de cada língua e com restrições devidas à modalidade de língua. (FERREIRA, 2010, pag.11)
}

Não se cede tão facilmente como antes à tentação de erigir como propriedades universais da linguagem as particularidades de uma língua ou de um tipo linguístico. Alargou-se o horizonte dos linguistas. Todos os tipos de línguas adquirem os direitos iguais de representar a linguagem. (BENVENISTE, 1995, pag. 06)

Ao abordar a LIBRAS (Língua Brasileira de Sinais), abordarei também as línguas de sinais dos outros países chamando-as todas genericamente de LS, pois pretendo fazer uma comparação entre as LS em relação ao seu direito de ser reconhecida como língua e também à problemática de sua comparação com as línguas orais. É importante lembrar que temos duas línguas que vivenciamos em nossa comunidade: a língua oral e a LS. As duas línguas (orais e visuais) têm caracteres idênticos em suas estruturas linguísticas e são diferenciadas nas modalidades, neste caso, as modalidades visuais e orais. Dessa maneira, Benveniste nos relata que não podemos deixar de reconhecê-la como linguagem, como principais fontes de conhecimento da cultura sobre um significado de um povo ou comunidade: 
De maneira geral, não podemos atualmente fiar-nos em nenhuma subdivisão natural ou cientificamente controlável do campo semântico da cultura local, porque não existe no momento nenhuma técnica para esse tipo de análise completa da cultura em elementos discretos: ao contrário, a linguagem é que é uma das nossas principais fontes de conhecimento da cultura (ou do mundo de significação) de um povo e das distinções ou divisões que aí se praticam. (BENVENISTE, 1995, pag.12-13)

Existem dois mundos de culturas: dos surdos e dos ouvintes, que são totalmente diferentes; a linguagem não difere entre os dois, pelo contrário, a linguagem desempenha o mesmo papel social e cultural para ambos os lados, o que vai diferir são as modalidades e também as estruturas linguísticas para cada lado. Para Benveniste (1995, pag. 17), “A linguística tornar-se-á então a teoria das combinações possíveis entre esses elementos e das leis universais que as governam”. (BENVENISTE, 1995, pag. 17). Na LS se associa a linguagem como complemento do "todo" da linguística. Sem a linguagem não podemos compreender a verdade, a transmissão, a língua e a cultura. Pois a sociedade só se sustenta pelo uso comum dos signos de comunicação.

\begin{abstract}
Quando os linguistas começaram, a exemplo de Saussure, a encarar a língua em si mesma e por ela mesma, reconheceram este princípio que se tornaria o princípio fundamental da linguística moderna: a língua forma um sistema. Isso vale para qualquer língua, qualquer que seja a cultura onde se use, em qualquer estado histórico em que a tomemos. Da base ao topo, desde os sons até as complexas formas de expressão, a língua é um arranjo sistemático de partes. (BENVENISTE, 1995, pag.22)
\end{abstract}

Podemos afirmar que a LS também forma um sistema linguístico, pois temos autores que contribuíram para a investigação da LS como língua: EUA - Willian C. Stokoe com coautoria D. Casterline e C. Cronoberg (1960); BRASIL- Lucinda Ferreira (1984, 1990, 1993, 1995), Felipe (1998), Karnopp (1994, 1999), Quadros (1997, 1999) e Capovilla (2005) e muitos outros, analisaram e investigaram o sistema da LS.

\footnotetext{
Mas é preciso também fazer justiça a precursores que não eram gramáticos e cuja obra subsiste, geralmente anônima, fundamental e menosprezada, tão presente em todos os instantes da nossa vida que não reparamos mais nela: quero falar dos inventores dos nossos alfabetos modernos. Que um alfabeto que possa haver inventado, que com um pequeno número de sinais gráficos se possa escrever tudo o que se pronuncia, só isso já demonstra a estrutura articulada da linguagem. O alfabeto latino, o alfabeto armênio são admiráveis exemplos de notação que se chamaria de fonemática. (BENVENISTE, 1995, p 25)
}

Um fato bastante interessante também é o alfabeto manual que surgiu da necessidade de empréstimo linguístico do alfabeto moderno para que se pudesse comunicar entre as duas 
línguas: oral e visual. As configurações de mãos, como são chamadas na LS, são um conjunto de formas visuais que compõem um alfabeto para comunicação entre as línguas. Para cada país que tem LS há um alfabeto diferente, porque cada qual faz jus ao empréstimo da língua oral de cada país. Veja exemplo do alfabeto manual brasileiro:

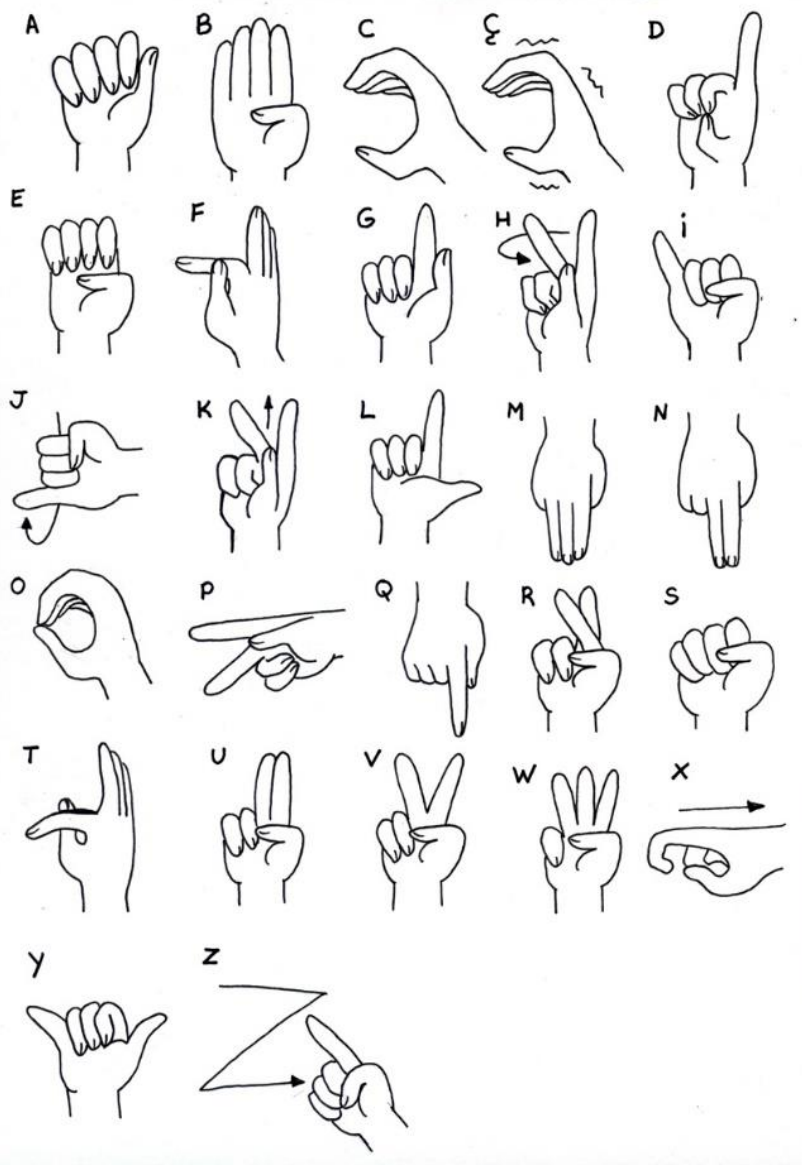

Figura 3- 1- Alfabeto Manual

\begin{abstract}
Não há um só linguista que hoje não lhe deva algo. Não há uma só teoria que não mencione seu nome. Algum mistério envolve sua vida humana, que cedo se retirou para o silêncio. É da obra que tratemos. A uma tal obra que apenas convém o elogio que a explica na sua gênese e faz compreender o seu brilho. (BENVENISTE, 1995, p 34)
\end{abstract}

Saussure é muito citado também nas pesquisas de LS, pois sua contribuição nos ajudou a compreender que a LS também se constitui uma língua natural. Eis uma citação de Saussure: "a língua é uma convenção e a natureza do signo convencional é indiferente. A questão do aparelho vocal que revela é secundária no problema da linguagem" (QUADROS, 2004), ou seja, não é só o aparelho vocal que revela a língua, as manifestações da linguagem 
se constituem também uma língua, tanto oral como visual. Saussure é muito respeitado entre os estudiosos das LS, pois suas teorias contribuíram para muitas investigações.

Em LS, o sinal também é um signo linguístico resultado da associação entre significante [=imagem visual] e significado [=conceito]. De acordo com o neurologista e psicólogo Oliver Sacks (2010), “os surdos geram línguas de sinais em qualquer lugar onde existam comunidades de surdos; é para eles a forma mais fácil e natural de comunicação". Além disso, a língua de sinais é altamente expressiva tanto quanto a língua falada. No entanto, em sua obra "Vendo Vozes", Oliver Sacks apresenta vários casos de pacientes que, devido a ambientes desfavoráveis (o que envolve o preconceito da sociedade em relação aos surdos, mas também outros fatores), desenvolvem suas capacidades linguísticas com mais tardar ou com maior dificuldade.

A afirmação de Saussure (2012), de que "o signo linguístico une não uma coisa e um nome, mas um conceito e uma imagem acústica" presta-se para os surdos muito bem, substituindo-se, na premissa, o termo "imagem acústica" por "imagem visual”. É da natureza do ser humano que, quando tem ausência de um dos cinco sentidos, consegue se adaptar muito bem, um suprindo o outro. No caso dos surdos, a ausência da audição é substituída pela visão; no caso do surdocego, a ausência dos dois sentidos (visão e audição) é substituída pelo tato, paladar e olfato. Então a imagem acústica é substituída pela imagem visual que nos constrói ideias, conceitos e fatos.

Muitas pessoas comparam a LS à linguagem animal baseadas no estudo descrito por Benveniste que faz uma reflexão sobre a linguagem das abelhas. Esta linguagem animal é associada a códigos de sobrevivência e vivência da natureza animal. Não se pode confundir a LS como uma linguagem de códigos, de gestos, pois ela é uma língua enquanto estrutura. Tal afirmação é corroborada pelas investigações comprovadas por Willian Stokoe que teve início em 1960 na Universidade Gallaudet University, onde comandou uma pesquisa sobre a Língua de Sinais Americana, denominada ASL (American Sign Language). Há outra confusão, pois, na ASL tem a palavra LANGUAGE, a qual tem sentidos e significados diferentes dependendo do contexto: pode ser traduzida como Língua, Idioma ou Linguagem. No Brasil, muitas pessoas associam a palavra LANGUAGE à palavra Linguagem ao se referir a LS. O sentido correto da tradução, contudo, é Língua, pois Stokoe conseguiu comprovar a ASL como uma língua por possuir raciocínio total de uma estrutura linguística de modalidade visual.

A LS não se deve confundir com símbolos ou com a linguagem animal baseada em códigos. Afirmamos que a LS é uma "linguagem humana" assim como as linguagens orais, 
onde se consegue estabelecer uma base de comunicação formada por conceitos, ideias da mente.

Para Benveniste (1995, pag. 65): “A Comunicação nas abelhas não sendo vocal, mas gestual, efetua-se necessariamente em condições que permitem percepção visual, sob a luz do dia; não pode ocorrer na obscuridade. A linguagem humana não conhece essa limitação".

Em se falando na obscuridade me lembro das pessoas surdacegas. Na LS se conhece sim a comunicação mesmo na obscuridade. Como um surdocego reconhece que "isto é uma mesa"? Como reconhece que "isto é uma árvore"? Como reconhece que "isto é uma flor"? Como reconhece que "esta é minha mãe"? Como? A natureza humana é realmente maravilhosa, pois o homem consegue se adaptar sempre que lhe falta um dos cinco sentidos. O surdocego tem habilidades táteis e olfativas que apreendem conceitos e formas de todas as coisas e fatos.

Nos estudos linguísticos da LIBRAS, de Quadros e Karnopp (2004), também se observa um número reduzido de morfemas que já constitui uma frase ou ideia de ação.

\begin{abstract}
Ao elaborar essa tábua das "categorias", Aristóteles tinha em vista arrolar todos os predicados possíveis da preposição. Sob a condição de que cada termo fosse significante no estado isolado. Pensava definir os atributos dos objetos; não apresenta senão seres linguísticos: é a língua que, graças às suas próprias categorias, permite reconhecê-las e especificá-las. (QUADROS e KARNOPP, 2004, pag. 76)
\end{abstract}

As categorias gramaticais da LS seguem o mesmo padrão de Aristóteles: predicados, verbos, substantivos, adjetivos; cada um tem sua função essencial na língua e enunciados. As LS são, portanto, consideradas pela linguística como línguas naturais ou como um sistema linguístico legítimo e não um problema do surdo ou uma patologia da linguagem. A língua de sinais atende a todos os critérios linguísticos de uma língua genuína no léxico, na sintaxe e na capacidade de gerar uma quantidade infinita de sentenças (QUADROS; KARNOPP, 2004).

\footnotetext{
Ao dizermos que a linguagem é simbólica, enunciamos ainda apenas a sua propriedade mais manifesta. É preciso acrescentar que a linguagem se realiza necessariamente numa língua e então surge uma diferença, que define para o homem o simbolismo linguístico: consiste que ela é aprendida, é coextensiva à aquisição que o homem faz do mundo e da inteligência, com os quais acaba por unificar-se. (BENVENISTE, 1995, pag. 92)
}

Em LS, toda aquisição da linguagem se baseia no visual, inclusive as ações. Quadros (1997) nos explica que a criança surda, filha de pais surdos, tem os mesmos estágios de aquisição da linguagem da mesma forma que uma criança ouvinte, filha de pais ouvintes. 
"Somente esse grupo de crianças surdas apresentam o input linguístico adequado e garantido para possíveis análises do processo de aquisição". Estes estudos estão contidos no livro de Ronice Miller Quadros intitulado Educação de surdos: aquisição da linguagem (QUADROS, 1997, 2008).

É uma grande ilusão considerar um termo simplesmente como a união de um certo som com um certo conceito. Defini-lo assim seria isolá-lo do sistema de que faz parte; seria crer que se pode começar pelos termos e construir o sistema somando-os, quando ao contrário é do todo solidário que é preciso partir para obter por análise os elementos que ele encerra. (BENVENISTE, 1995, pag. 99)

É interessante esta consideração no caso da língua de sinais, pois um conceito não se baseia apenas na configuração de mão; é necessário um conjunto de sistemas (movimento, localização, direção, tipo de configuração de mão) a partir do qual construímos o conceito do sinal, o mesmo ocorre nas línguas orais quando da formação fonológica do som.

De acordo com Benveniste (1995, pag. 101-2):

Segue-se que muitos sistemas podem e devem ser confrontados: "aplicando os princípios da fonologia" a muitas línguas, todas diferentes, para pôr em evidencias os seus sistemas fonológicos, e estudando a estruturas desses sistemas, não demoramos a observar que certas combinações de correlações se encontram nas mais diversas línguas, enquanto outras não existem em parte nenhuma. Essas são as leis das estruturas dos sistemas fonológicos. (BENVENISTE,1995, pag. 1012):

Quadros (2004) nos apresenta, também, as estruturas linguísticas conforme a fonologia de sinais: “A LIBRAS, assim como outras LS, é basicamente produzida pelas mãos, embora movimentos do corpo e da face também desempenham funções". Seus principais parâmetros fonológicos são locação, movimento e configuração de mão, conforme exemplificados na figura a seguir: 


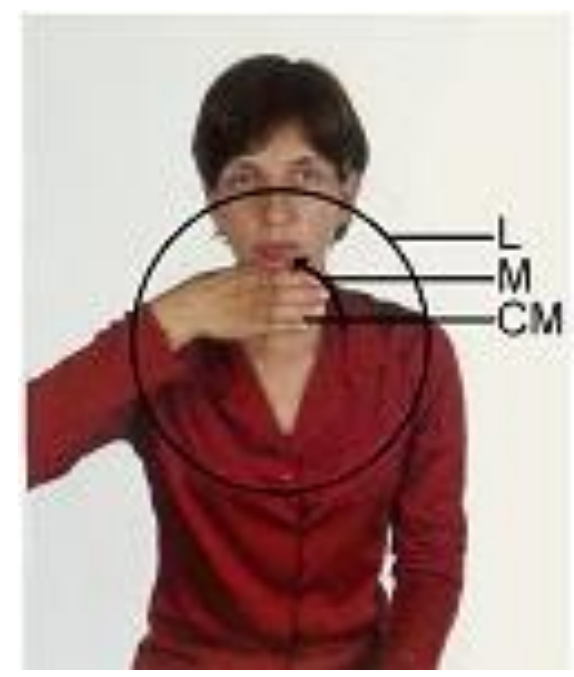

Figura 4 - Os Parâmetros fonológicos da LIBRAS. Retirado de Quadros e Karnopp (2004, pag. 51).

No segundo livro de Benveniste, Problemas de Linguística Geral II, o autor explica afirmando que Saussure é o grande responsável pela sua paixão pela linguística. É através dele que a linguística se transforma na ciência da investigação sobre os fatos da linguagem, que se tornou substância a ser analisada e investigada para melhor compreensão da evolução humana dentro da inteligência intelectual do homem.

Ao analisar a LS sempre se procurou compreender a língua visual não só como estrutura, mas sobretudo um acontecimento. Conforme os estudos e investigações científicas da LS, ela é vista como um acontecimento da compreensão da língua visual como sujeito histórico e produtor de sentidos e significados. As imagens são carregadas de sentidos afetados pelo real da linguagem vivenciada, de acordo com seu status social inserido. A LS sobreviveu às repreensões ouvintistas, pois sua representação e preservação está na linguagem inata em que as pessoas surdas nascem tendo a linguagem visual como meio de comunicação e estruturação linguística. Na concepção de Benveniste (1989, pag. 23):

Não há existência comum sem língua. Consequentemente é impossível datar as
origens da linguagem, não mais que as origens da sociedade. Mas nós nunca
saberemos como eles falavam. Estamos certos de que não alcançaremos nada de
mais elementar pela reconstrução a mais ousada. A ideia de que o estudo linguístico
revelaria a linguagem enquanto produto da natureza não pode mais ser sustentada
hoje. Vemos sempre a linguagem no seio da sociedade, no seio da cultura. E se digo
que o homem não nasce na natureza, mas na cultura, é que toda criança e em todas
as épocas, aprende necessariamente com língua, os rudimentos de uma cultura.
(BENVENISTE 1989, pag. 23)

Toda língua é responsável pela transformação e formação social e intelectual do ser humano. É através da cultura que se pode manter e fortalecer a língua. É assim que podemos também afirmar que a Língua de Sinais teve sua preservação como língua dentro da 
comunidade surda por meio de reuniões, encontros, oportunidades de identificação mútua e recíproca. Esses encontros aconteciam nas praças, nas associações criadas, nas festas e nas casas de amigos ou de familiares surdos. Sabe-se que a língua de sinais existe há muito tempo, mas não sabemos se mantém os mesmos sinais, sempre há mudanças. As crianças surdas que são filhas de pais surdos crescem num ambiente linguístico da própria língua de sinais, proporcionam um melhor desenvolvimento no funcionamento do processo de produção de sentidos do sujeito.

De acordo com Benveniste (1989, pag. 29):

A linguística é a tentativa de compreender esse objeto evanescente: a linguagem, para estudá-la como se estudam os objetos concretos. Trata-se de transformar as palavras que voam - o que Homero chamava as "palavras aladas" - em uma matéria concreta, que se estuda, que se disseca, onde se delimitam unidades, onde se isolam níveis. (BENVENISTE, 1989, pag. 29):

Esta expressão de Homero, "palavras aladas", é encantadora. Lembra-me que na Língua de Sinais ocorre a mesma coisa, elas são palavras/sinais aladas, mas na forma concreta, visual. Dentro de um sinal contém sua configuração de mão, localização e movimento, cada sinal tem seu significado. Benveniste aborda, através de Saussure, a "linguagem dos surdos", porém seria correto hoje falarmos em "língua de sinais". Vejamos:

O que é o signo? É uma unidade de base de todo o sistema significante. O senhor tem um sistema significante que é uma língua. Saussure citou dois ou três: a linguagem dos surdos-mudos, por exemplo, que opera com outras unidades que são unidades gestuais; ele citou igualmente, isto é mais discutível, o ritual dos gestos de polidez. Mas é um repertório limitado: não se pode dizer com os gestos de polidez tudo o que a linguagem permite dizer, mas no geral é a mesma ordem. (BENVENISTE, 1989, pag.33)

Permitimo-nos uma observação sobre a palavra "gestos" empregada por Benveniste que, na verdade, são "sinais". Não são um repertório limitado, pelo contrário, por meio deles se pode sim exprimir ideias, poemas, perguntas e muitas outras formas, assim como a língua oral. Sobre os estudos linguísticos elaborados por Quadros e Karnopp, os mesmos estão de acordo com o que Saussure preconiza sobre as unidades gestuais, conforme segue o exemplo a seguir sobre um sinal: 

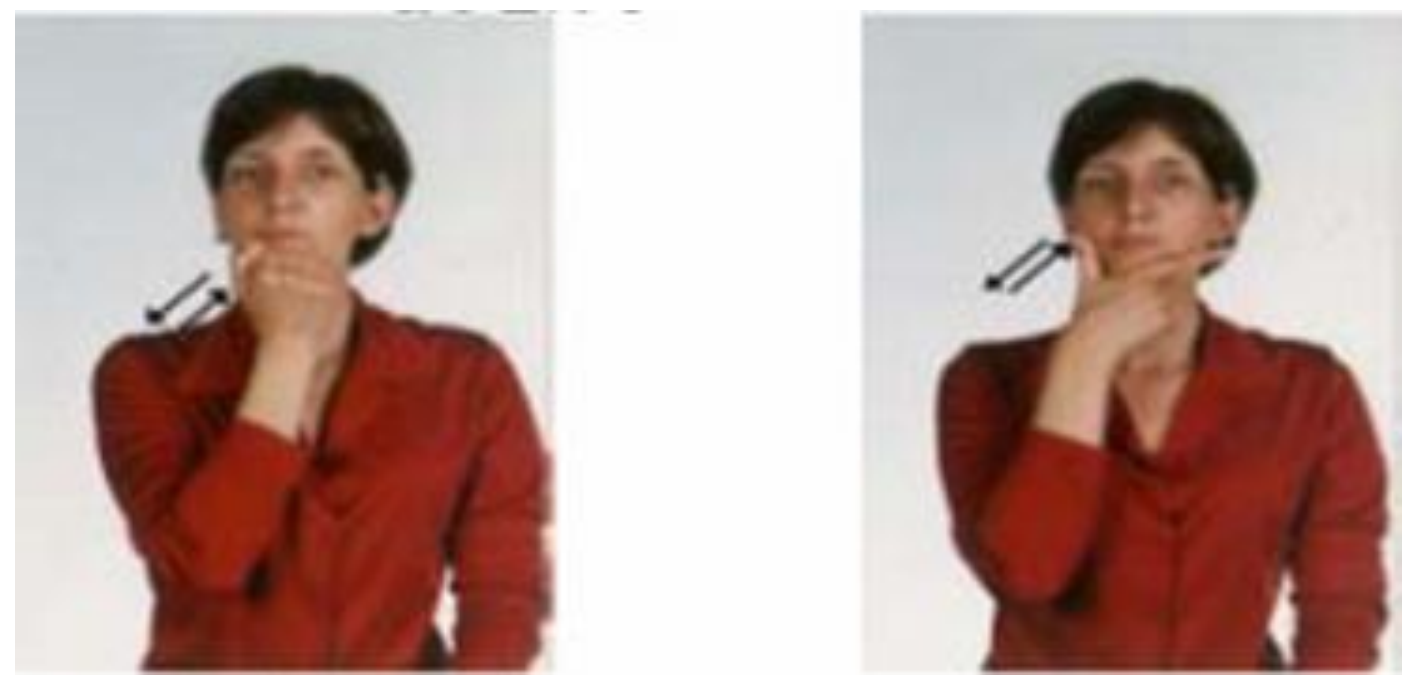

Figura 5 - PEDRA --- QUEIJO: (QUADROS e KARNOPP, 2004, pag. 82)

Ambos os sinais possuem o mesmo movimento ( $\rightleftarrows$ ) porém possuem as

configurações de mãos diferentes: no caso do sinal PEDRA, a configuração de mão é

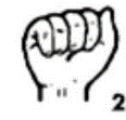

enquanto do sinal QUEIJO a configuração de mão é

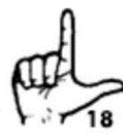

isso diz respeito aos conceitos da área de morfologia e fonologia da Língua de Sinais, os quais correspondem, em relação às palavras de Saussure, às unidades gestuais.

É interessante observar que Benveniste coloca algumas citações de Saussure sobre a Semiologia, pois é através deste estudo que podemos compreender a natureza dos signos dentro do sistema da língua. A Semiologia nos ajuda a compreender o sistema de ideias geradas pela língua, seja oral ou de sinais. Tais afirmações podem ser explicitadas conforme Benveniste (1989, pag. 49):

\begin{abstract}
A língua se apresenta sob todos seus aspectos como uma dualidade: instituição social, ela é produzida pelo indivíduo; discurso contínuo, ela se compõe de unidades fixas. É que a língua é independente dos mecanismos fono-acústicos da fala; ela consiste em "um sistema de signos onde, de essencial, só existe a união do sentido e da imagem acústica, e onde as duas partes do signo são igualmente psíquicas". Onde a língua acha sua unidade e o princípio de seu funcionamento? Em seu caráter semiótico. (BENVENISTE 1989, pag. 49):
\end{abstract}

É muito importante afirmar que na Língua de Sinais a Semiologia também faz parte do contexto de estudos, pois é através da união do sentido (do sinal) com a imagem (neste caso seria a imagem visual para o surdo, e a imagem construída através do tato no caso do surdo- 
cego) que a comunicação ocorre de maneira compreensível dentro da língua em sua comunidade.

Os estudos semiológicos corroboram para o conceito da Língua de Sinais enquanto língua, pois, a título de ilustração, tem-se o entendimento de que, para produzir um entendimento abstrato na língua de sinais, é necessário que a explicação/tradução seja uma “explanação de imagens" e não um conjunto de sinais traduzidos pela língua portuguesa. Tal teorização evidencia a necessidade de se aprofundarem os estudos da Semiologia em relação à LS, pois ainda são poucos. Saussure consolidou a Semiologia como a "ciência que estuda a vida dos signos no seio da vida social" sugerindo sua inclusão nas ciências da linguagem, como a nova área de estudos, dentro das ciências humanas.

Benveniste, porém, se preocupa com outro aspecto: quer saber onde está a natureza linguística do signo? No meu entendimento, se não existisse o signo, a língua não existiria. É graças ao signo que nós construímos a interatividade da língua, seja ela oral ou de sinais.

Há uma afirmação de Benveniste sobre as diferenças entre a Semântica e a Semiótica, em que o autor deixa claro que as duas faculdades são dissociadas, ou seja, é preciso apartar (escolher, separar) o que está unido ou agregado (física ou moralmente).

As duas faculdades são consideradas "irmãs", pois sempre uma precisa da outra para que a emissão de mensagens seja totalmente compreendida pelo outro. A ausência de uma, pode sim encontrar uma barreira na comunicação.

Segundo Benveniste (1989, pag. 66):

\begin{abstract}
Que se trata de duas ordens distintas de noções e de dois universos conceptuais, pode-se mostrar ainda pela diferença quanto ao critério de validade que é requerido por um e por outro. O semiótico (o signo) deve ser RECONHECIDO; o semântico (o discurso) deve ser COMPREENDIDO. A diferença entre reconhecer e compreender envia duas faculdades distintas do espírito: a de perceber a identidade entre o anterior e o atual, de uma parte, e a de perceber a significação de uma enunciação nova, de outra. Nas formas patológicas da linguagem, as duas faculdades estão frequentemente dissociadas. (BENVENISTE, 1989, pag. 66)
\end{abstract}

Benveniste aborda, ainda, o "tempo": como é expresso pela linguagem oral, suas configurações, suas formas e condições de produção. Em LIBRAS também empregamos o "tempo visual" para situarmos a narrativa no enunciado e também o interlocutor.

A enunciação se realiza graças às inúmeras experiências socioculturais em que vive o enunciador. Do mundo que nos cerca, depreendemos e categorizamos cores, sons, imagens, objetos, os quais, categorizados e constituindo-se signos, produzem a linguagem do ser humano. Todo enunciado se reproduz a partir da nossa análise, da nossa conclusão e da nossa 
formação intelectual recebida. Na LS o enunciado é formado pelas dêixis ${ }^{17}$ no qual utilizamos a configuração de mão D, mais especificamente como um pronome, conforme Quadros, Resende e Pizzio (2009), no caso de "nós", formado pela configuração de mão V, formam enunciados de localização da pessoa e número, para cada enunciado existe os números de pessoas.

De acordo com Quadros, Resende e Pizzio (2009, pag. 02):

Tradicionalmente, os pronomes têm sido tratados como substitutos dos substantivos, mas sua função mais básica é a função dêitica ou indexical. Isto é, pronomes são, para serem definidos como dêixis, primeira e principalmente um local espaço-temporal no contexto do enunciado. (QUADROS, RESENDE E PIZZIO,2009, pag. 02)

E para Benveniste (1989, pag. 83):

A enunciação supõe a conversão individual da língua em discurso. Aqui a questão é ver como o "sentido" se forma em palavras, em que medida se pode distinguir entre as duas noções e em que termos de descrever sua interação. É a semantização da língua que está no centro deste aspecto da enunciação, e ela conduz à teoria do signo e à análise da significância. (BENVENISTE, 1989, pag. 83)

O sentido e o significado da importância da Língua enquanto organizadora e sustentadora da sociedade estão contidos no fato de que a sociedade depende da língua para evoluir, para comunicar-se, para construir ideias, para construir ordem. É graças à língua, na sua estrutura organizada, que a sociedade evolui e caminha. Na LS não é diferente, os sinais constituem conceitos e significados abstratos, por meio dos contextos dos sinais através dos espaços e direções em que os sinais são realizados, além dos tópicos e direções do olhar para uma determinada frase. A língua oral, portanto, é o instrumento de comunicação dos ouvintes assim como a LS se constitui no instrumento de comunicação entre surdos. A língua, tanto a oral quanto a de sinais, permite uma infinita possibilidade de produção de variadas

${ }^{17}$ Em linguística, dêixis ou referência dêitica é a associação conceitual entre uma ocorrência de uma palavra cujo significado depende do contexto, e a entidade que essa ocorrência representa. Por exemplo, na sentença "eu estarei aqui amanhã", a pessoa representada pela palavra "eu", o local representado por "aqui", e o dia representado por "amanhã" são exemplos de dêixis. Na sentença "conversaremos", a conjugação do verbo indica um tempo no futuro e um conjunto de pessoas, que são exemplos de dêixis, pois suas exatas identidades dependem do contexto. As palavras que rotineiramente manifestam a dêixis são chamadas de dêiticos. Na língua portuguesa, os dêiticos incluem os pronomes como "eu", "lhe", "isto"; os artigos como "o", "as"; a maioria dos advérbios de lugar e de tempo, como "hoje", "logo", "aqui", "perto"; as terminações verbais; e várias outras categorias, até mesmo certos verbos como "ir" e "vir". O mesmo ocorre na Libras, a dêixis é representada pela configuração de mão "D" também possuem pronomes "eu, você, ele/ela," tempo de "hoje" "aqui", "perto", "ir", "vir", são elementos dêiticos na LS, Libras. 
mensagens. Esta é a única propriedade pela qual a língua se torna uma estrutura capaz de produzir um número incalculável de enunciados na comunicação. Então, Benveniste (1989, pag. 98) nos possibilita compreender que: “[...] a língua interpreta a sociedade. A sociedade torna-se significante na e pela língua, a sociedade é interpretada por excelência da língua”.

Seria interessante estudar e investigar mais a fundo na Língua de Sinais este classificador, como complemento da formação do verbo + substantivo de uma ação. Nos dois livros de Benveniste há muitas categorias que tratam das pronúncias das Línguas Orais. Ainda faltam estudos tão minuciosos e elaborados em relação à Língua de Sinais como os que foram feitos a respeito da língua oral.

Muitos aspectos da teoria desenvolvida por Benveniste, contudo, podem ser relacionados à LS por meio de estudos comparativos considerando a semelhança entre as línguas oral e de sinais enquanto sistemas. Nesse sentido, evidencia-se uma demanda bastante grande de estudos linguísticos a respeito da LS.

\subsection{Conceito de “texto" sobre a Língua de Sinais pela Semiótica Russa de Lótman}

O texto é algo mais do que um conjunto de palavras, imagens, sinais. O texto faz parte da semiosfera a qual Lótman (1978) descreve como a totalidade do espaço semiótico. Merrel (2003, pag. 165) nos exemplifica citando Lótman (1978) que a semiosfera "é o resultado e a condição para o desenvolvimento da cultura”. Estamos submersos no texto, nas mais diversas linguagens: na escrita, nas imagens, na música, nos artefatos culturais, nas línguas. O texto é o sentido disseminado na Semiosfera, onde as coisas e as ações trazem sentido e significado à vida.

De acordo com Machado (2013, pag. 67), na Semiótica da Cultura, do grupo da Escola de Tartu-Moscou, na visão da Logosfera $^{18}$ e da Semiosfera ${ }^{19}$, texto é um "mecanismo elementar que conjuga sistemas e, com isso, confere unidade pela transformação da experiência em cultura, como conceito fundamental da moderna semiótica” (MACHADO, 2003, pag.168).

\footnotetext{
${ }^{18}$ Segundo Machado (2013, pag. 67 a 70) Logosfera e Semiosfera estão interligados no sentindo de sistema de transformação social do pensamento, segundo a lógica de Lótman e Vérnádski, como consciência que manifesta como linguagem humana criando em entorno de natureza, ou seja é o reino da palavra, porta-voz da informação semiotizada e nascente da cultura.

${ }^{19}$ Segundo Machado (2013, pag. 69) Segundo Lótman, "a unidade da semiose, a menor função do mecanismo, não é a linguagem isolada mas a totalidade do espaço semiótico da cultura em questão". Aqui a Semiosfera suplanta a Logosfera.
} 
Mais que tudo isso, o texto se representa como os recursos da linguagem, onde somos capazes de codificar, identificar, sentir, pensar e compreender o sentido. A relação leitor-texto se mergulha numa função de relações de trocas, de absorção entre leitor e texto. Para Lótman (1978, pag. 101) todo texto deve estar decodificado no mínimo duas vezes: pelo código que apreende a informação e a transforma num conjunto organizado de signos e pelo contexto sistêmico da cultura historicamente construído.

Pensando nas línguas de sinais, Lótman (1978, pag. 101) também elabora o conceito de texto como uma modalidade visual, bem diferente da modalidade oral. Para argumentarmos sobre a condição de língua natural inerente à língua de sinais, citamos Quadros e Karnopp (2007, pag.30-31), que citam o pesquisador Willian Stokoe (1960), que conseguiu comprovar a língua de sinais como língua natural:

\footnotetext{
Stokoe observou que os sinais não eram imagens, mas símbolos abstratos complexos, com uma complexa estrutura interior. Ele foi o primeiro, portanto, a procurar uma estrutura, a analisar os sinais, dissecá-los e a pesquisar suas partes constituintes. Comprovou, inicialmente que, cada sinal apresentava pelo menos três partes independentes (em analogia com os fonemas da fala) - a localização, as configurações de mãos e os movimentos - e que cada parte possuía um número limitado de combinações. (QUADROS e KARNOPP, 2007, pag. 30-31
}

Tomemos como ponto de partida para analisar o conceito de texto sobre a língua de sinais definido por Lótman (1978) a poesia surda "Caterpillar" de Ian Sanborn ${ }^{20}$. O poema fala sobre a aventura de uma lagarta que se transforma em borboleta. Sanborn discorre, entre classificadore ${ }^{21}$ de língua de sinais e efeitos visuais, a narrativa sobre a lagarta.

Dentro do conceito de texto nas línguas de sinais, usamos o classificador que é um sistema modelizante "relacional constituído por elementos e regras combinatórias que se define no sentido de criar estruturalidade que se define, assim como uma fonte de modelo" (MACHADO, 2003, pag.167).

O classificador na língua de sinais é considerado morfologicamente um elemento de “dupla articulação, isto é, unidade significativa ou morfema constituído a partir de unidades arbitrárias e sem significado ou fonemas" (FERREIRA, 2005). Os classificadores aparecem no verbo categorizando o referente dos seus argumentos em termos de forma, consistência,

\footnotetext{
$20<$ https://www.youtube.com/watch?v=MTgGQnxX5Uw>. Publicado em 30 de mar. de 2014.

${ }^{21}$ Classificadores conforme Pizzio, Campello, Rezende e Quadros (2009, pag. 14): O classificador é um tipo de morfema, utilizado através das configurações de mãos que podem ser afixado a um morfema lexical (sinal) para mencionar a classe a que pertence o referente desse sinal, para descrevê-lo quanto à forma e tamanho, ou para descrever a maneira como esse referente se comporta na ação verbal (semântico).
} 
tamanho, estrutura e posição. O que podemos observar é que os classificadores ajudam a compor uma estrutura narrativa da história a ser composta.

Dentro do classificador podemos considerar como um conceito de texto, "texto visual" que, para Lótman (1978, pag. 101): "É difícil uma definição do conceito de texto. Primeiro que tudo é preciso protestar contra a assimilação do <texto> à representação da totalidade da obra artística".

A exploração do espaço físico, o corpo e os dedos exploram elementos comunicativos de uma narrativa visual em que "Caterpillar" mostra a representação da estrutura linguística da poesia. Tomamos como análise do conceito de texto os vídeos cujas cenas se encontram na figura 4, captando as sequências em figuras para melhor analisarmos e correlacionar com o conceito de texto de Lótman (1978).
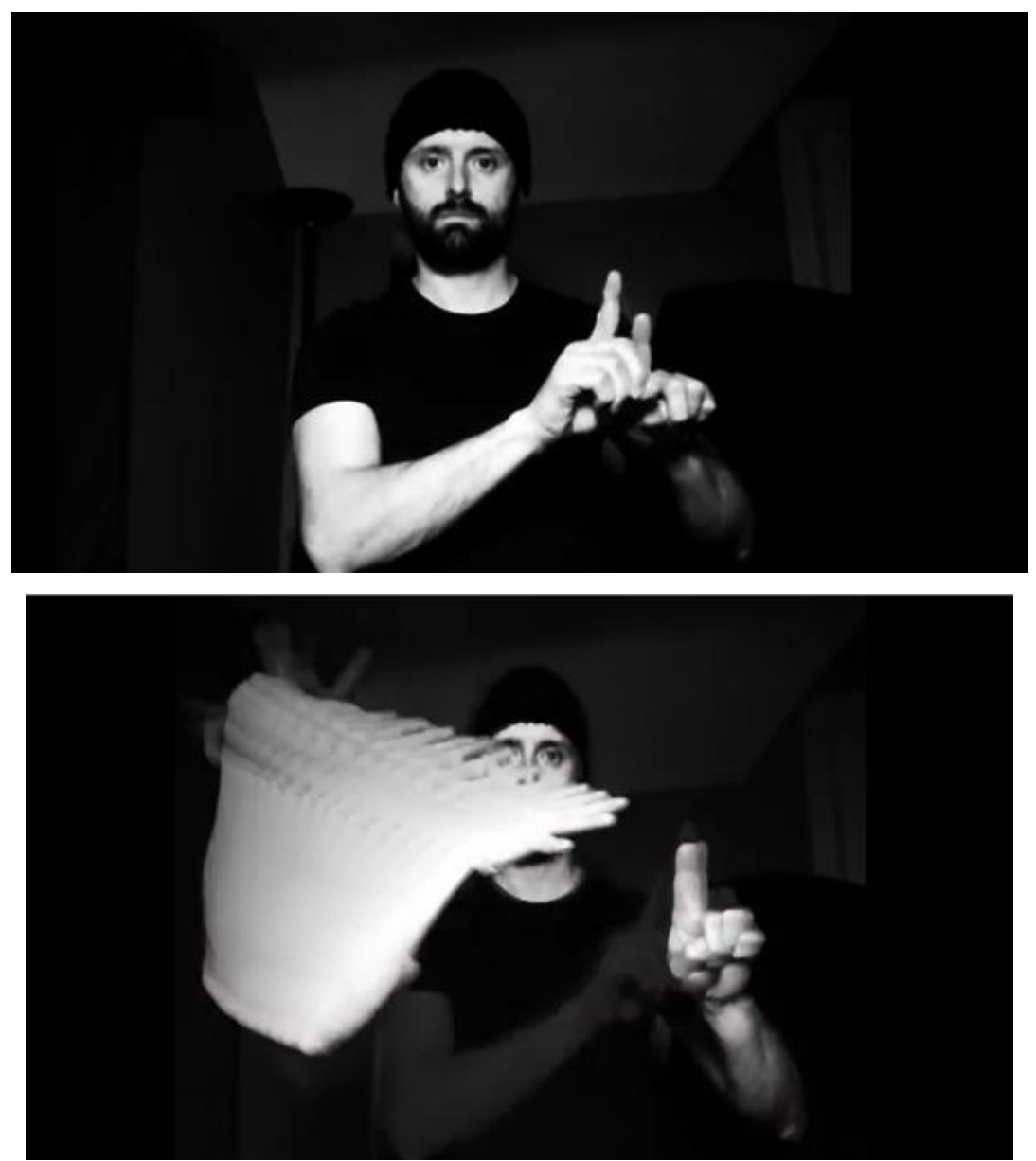


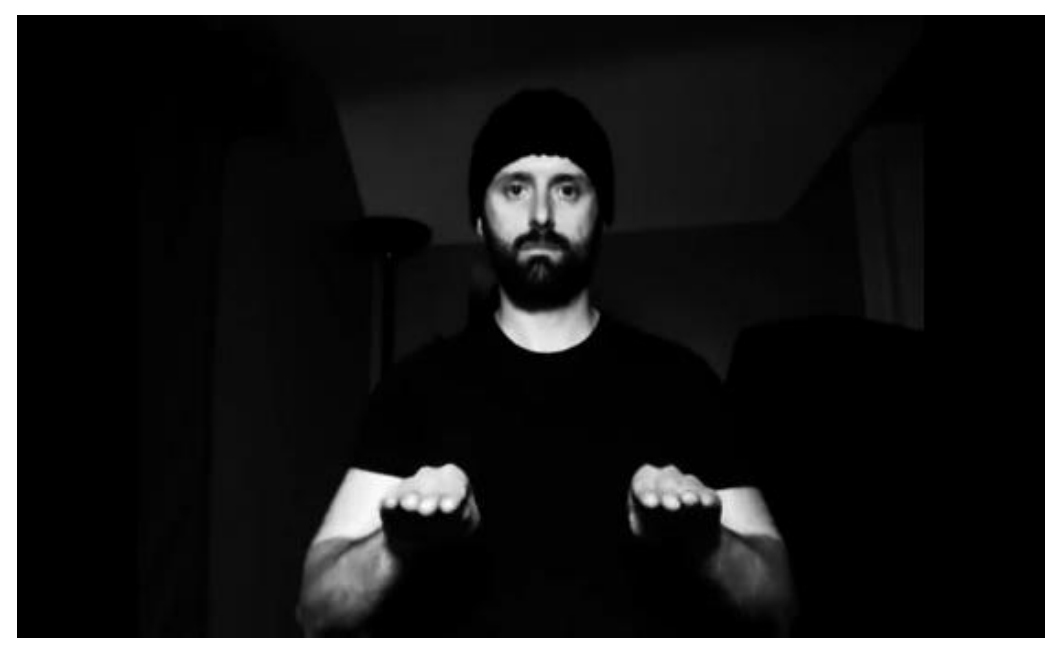

Figura 6: início da frase: "Em uma terra, foi formado uma árvore em que foi sustentada pelo sol" https://www.youtube.com/watch?v=MTgGQnxX5Uw>. Publicado em 30 de mar. de 2014.

A "grandeza da sua entropia", defendido por Lótman (1978) na poesia surda se manifesta principalmente pelos movimentos, classificadores e dedos, além dos efeitos visuais do filme em câmera lenda sobre os movimentos dos sinais; o autor Sanborn possibilita uma linguagem da narrativa textual sobre o "nascimento de uma árvore”. É evidente que muitos sinais, classificadores nesse caso, possuem iconicidade e arbitrariedade representativas da natureza visual entre o signo e significado. $\mathrm{O}$ autor também possibilita uma facilidade interpretativa visual para as pessoas que ainda não têm conhecimento da língua de sinais e a oportunidade de passar a mensagem fazendo uso dos movimentos e classificadores. Dessa forma, se tornam as ligações extratextuais da obra, como diz Lótman (1978, pag. 102):

\begin{abstract}
As ligações extratextuais de uma obra podem ser descritivas como a relação do conjunto dos elementos a partir do qual foi realizada a escolha do elemento utilizado que é dado. É perfeitamente evidente que a utilização de um ritmo num sistema que não admite outras possibilidades, que admite uma alternativa, a escolha de uma possibilidade ou que se dá cinco meios igualmente prováveis de construção do verso, de que o poeta não utiliza senão um, dar-nos-ão construções artísticas completamente diferentes, se bem que o lado materialmente fixo da obra - o seu texto - permaneça inalterável (LÓTMAN, 1978, pag. 102).
\end{abstract}

Outros elementos importantes são as expressões faciais como composto dos enunciados. Mesmo a figura 6, que representa o congelamento das informações visuais da expressão facial, não deixa de ser um emissor. Na poesia surda, a expressão é a fala da comunicação que a narrativa visual representa. Para Lótman (1978, pag. 104), a expressão é "um texto é fixado por meio de determinados signos e, neste sentido, opõe-se às estruturas extratextuais". Por meio dos signos visuais representados pelos dedos, corpo e classificador a expressão torna-se parte da narrativa textual visual. 
A partir deste estudo da poesia "Caterpillar", analisando-se os estudos de Lótman (1978), podemos contextualizar as diferentes modalidades das línguas (visual, escrita e oral) como parte da natureza da semiosfera cultural em que Lótman (1978) nos orienta para que as coisas e fatos nos tragam sentido à existência das coisas, dos seres e dos fatos. 
CAPÍTULO 3

"ME VER" E “TE VER" 
Em que plano de vivenciamento está a Imagem Externa e Interna que eu vejo sobre o mundo externo em que adquiri a vivência e linguagem? Sobre minha imagem externa e interna de mim, eu me vejo como? Por quê?

Neste capítulo desenvolvemos algumas reflexões sobre a percepção do ver e do ouvir no meu universo e minha essência de Ser Surda sobre a escrita como eu a vejo segundo a minha linguagem e visão de percepção surda.

\section{1 "Me ver" significa "Me ouvir" e "Te ver" significa "Te ouvir"}

O que entendemos por imagens? As imagens são nossas representações de um mundo externo para o interno onde construímos nossa linguagem e conhecimento. A imagem representa nossa realidade, mas também representa a conservação (memória) das relações sociais entre a comunidade que vivenciamos, seja ela família, escola, eventos diversos (DAVALON, 2015 pag. 25). Toda imagem desenvolve uma atividade de produção de significação, ou ainda pela informação recebida, uma produção cultural sobre representar os objetos do mundo ou ainda mais as informações que ela pode nos fornecer. Como afirma Davalon (2015, pag. 26-7):

\footnotetext{
Com efeito, aquele que observa uma imagem desenvolve uma atividade de produção de significação; esta não lhe é' transmitida ou entregue toda pronta. Esse estado de coisas abre, como aliás insistem em nos fazer observar, a uma liberdade de interpretação (o que quer dizer que o conteúdo "legível", ou antes "dizível" pode variar conforme as leituras); mas o que faz também - e não se poderia esquecer este ponto - com que a imagem comporte um programa de leitura: ela assinala um certo lugar ao espectador ( ou melhor: ela regula uma série com a passagem de uma posição de receptor no curso da recepção) e ela pode "rentabilizar" por si mesma a competência semiótica e social desse espectador. (DAVALON, 2015, pag. 267)
}

Muitas vezes eu procurava entender o mundo externo. Como seria minha imagem externa e interna? Me via como "Narciso" com seu reflexo no espelho, procurando o mundo externo ser como eu; buscava através da minha imagem externa um entendimento sobre a vivência do outro. Depois que adquiri a surdez aos 03 anos de idade meu mundo de percepção externa se transformou. Minhas visões passaram a ser mais aguçadas, passaram a ter uma sensação de percepção maior de interpretação. É a minha visão que recebia a imagem externa para uma provocação de auto sensação interna de percepção do externo e uma relação de trocas simbólicas entre o mundo ouvinte e surdo. 
Eu me vivencio de dentro, assim como Bakhtin em sua explanação sobre o Eu, sobre a vivência externa:

\begin{abstract}
Quando contemplo no todo um homem situado fora e diante de mim, nossos horizontes concretos efetivamente vivenciáveis não coincidem. Porque em qualquer situação ou proximidade que esse outro que comtemplo possa estar em relação a mim, sempre verei e saberei algo que ele, da sua posição de fora e diante de mim, não pode ver: as partes de seu corpo inacessíveis ao seu próprio olhar - a cabeça, o rosto e sua expressão -, o mundo atrás dele, toda uma série de objetos e relações que, em função desta ou daquela relação de reciprocidade entre nós, são acessíveis a mim e inacessíveis a ele. Assumindo a devida posição, é possível reduzir ao mínimo essa diferença de horizontes, mas para eliminá-la inteiramente urge fundir-se em um todo único e torna-se uma só pessoa (BAKHTIN, 2015. pag. 21).
\end{abstract}

Sobre o ambiente em que adquiri a linguagem, não foi necessariamente o som que raramente ouvia que me levou a adquirir os conceitos da linguagem. Foram as imagens e experiências vividas que provocaram em mim um fenômeno da linguagem. O linguista afirma que "A linguagem tem um lado individual e social" (SAUSSURE, 2012, pag.40). Assim, toda a minha linguagem foi construída buscando sempre compreender os conceitos das imagens que via no dia a dia.

Tenho refletido em muitos momentos sobre o que vem a ser a linguagem? De que forma as pessoas surdas adquirem linguagem? Linguagem é o sentido das coisas, das nomeações, dos conceitos e ideias de cada coisa. Surdos são capazes de adquirir a linguagem? De que forma?

Há teorias bastante diversificadas sobre a concepção de linguagem. Podemos explanar a concepção de linguagem pela filosofia da linguagem de Bakhtin, e Saussure, linguagem segundo a teoria behaviorista, linguagem segundo teoria Gerativista de Noan Chomsky. Todas as teorias e filosofias têm a linguagem como desenvolvimento social, intelectual, inatista como forma de conhecimento adquirido pela pessoa.

Sobre a linguagem como construção social da pessoa e da língua utilizo-me da filosofia de Peirce, analisada por Santaella. Sobre o conceito de linguagem, Santaella (1979, pag. 12) nos explica que:

Considerando-se que todo fenômeno de cultura só funciona culturalmente porque é também um fenômeno de comunicação, e considerando-se que esses fenômenos só comunicam porque se estruturam como linguagem, pode-se concluir que todo e qualquer fato cultural, toda e qualquer atividade ou prática social constituem-se como práticas significantes, isto é, práticas de produção de linguagem e sentido. (SANTELLA, 1979, pag. 12) 
A partir do momento em que perdi a audição e ganhei a visão aguçada, minha percepção de mundo passou a ser um mosaico de construções de sentidos e significados de todo conceito que vivenciava. Toda experiência exterior provocava em mim a necessidade de tentar me sentir "incluída", de sentir fazer parte do corpo da sociedade, pois tudo parecia separado, uma fronteira entre os dois mundos. Mas essas percepções são privadas, nenhuma pessoa poderia perceber como sentia necessidade de me comunicar. Mesmo que eu ouvisse pouco, me sentia "vazia", os sons não penetravam em meu cérebro, nem os signos de uma palavra. Minha mãe relata sobre essa minha experiência em seu corpus:

\footnotetext{
Ficou um tempo ouvindo uns 50\%, depois perdia novamente a audição. Os médicos optaram por não pôr aparelho de audição.

Ela ficava uma época sem ouvir nada, depois voltava a ouvir e depois aprendia tudo o que não tinha aprendido. Era muito interessante e assim foi até chegar aos 6 anos, entrou no Pré-escolar. Ela reclama da professora até hoje, eu não sei porque, ela era muito boa, talvez não tinha compreendido o seu emocional pois ela necessitava de muita amizade e atenção e ela tinha muito pouco. Esse foi um dos motivos que eu mais mexi com as pessoas.

Ana Paula aprendeu sozinha a ler os lábios das pessoas. A partir do $1^{\circ}$ momento que ela parou de ouvir ela começou a ler os lábios das pessoas, nem mesmo nós pais percebemos. Quando fez os $1^{\circ}$ testes (profissional) percebemos que ela lia os lábios e começou a pôr um objeto na frente da boca para ela não perceber e não ler os lábios. Até hoje ela é assim: lê perfeitamente os lábios das pessoas, sente dificuldade se o homem tem bigode, se a pessoa não articular direito, quando criança fala muito rápido. (MARIA DE FÁTIMA, 2015, anexo 1)
}

Como eu pude captar as informações recebidas? Os sons poderiam ter influenciado a minha linguagem? Alguns sim, outros não, tudo depende do meu corpo e do ambiente social em que estou. Minha mãe dizia que eu sabia o que ela dizia, mas ela não sabia o que se passava no meu interior em tentar entender o que ela queria dizer. Eu procurava sempre um significado buscando observar as interpretações das imagens.

Quando eu era criança ficava tentando buscar o sentido; eu ficava observando as leituras labiais, as expressões faciais, os movimentos do corpo e rosto, dos movimentos das apontações de dedos; era o momento em que sentia a necessidade de observar e interpretar. Até hoje nas conversas orais, mesmo sabendo ler lábios, apesar de ser apenas ver e ler um lábio de cada vez, por que é impossível ver vários lábios ao mesmo tempo, eu ficava e ainda fico a observar as imagens, sempre procurando encontrar um sentido e significado dessas conversas, falas orais. Santaella (1979, pag. 14) descreve muito bem sobre a capacidade inata de uma criança: 
Porque uma criança é capaz de ficar talvez, dezena de minutos, na pura absorção contemplativa das qualidades de movimento de um móbile? O que é rara faculdade do artista de ver o que está diante dos olhos, as cores aparentes da natureza, como elas se apresentam sem substituí-las por nenhuma interpretação? É a capacidade de absorver ícones poros abertos à simples e despojada possibilidade qualitativa das coisas.(SANTELLA, 1979, pag. 14)

E a escrita? Constantemente meus amigos surdos são cobrados nas escolas e também precisam saber ler e escrever em Língua Portuguesa. Mas não é a realidade deles que os professores de português desejam, pois há uma grande diferença entre a Língua Portuguesa e a LIBRAS. Essa realidade me fez refletir por que só eu consegui adquirir a escrita e leitura. Também me sinto injustiçada por ver tantos surdos que ainda não conseguem nem interpretar uma palavra escrita. Mas como adquiri essa competência? Observamos através do corpus de minha mãe e também professora $\mathrm{Cida}^{22}$ :

Cada palavra ela precisava desenhar e compreender. Depois tinha as frases. Tudo precisava desenhar. Aprendia todas as sílabas com " $A$ " depois vinha com "E" e a criança já sabia ler. Tudo a professora entrava em contato conosco. Eu me lembro que ela começou o "AR" e ela não conseguia entender e foi a partir da palavra "mar" ela desenhou e foi embora. Em junho, ela lia tudo. Nunca vi tanta rapidez para ler e compreender um texto. (MARIA DE FÁTIMA, 2015, anexo 1)

3- Ao receber a aluna surda, em 1987 , na $1^{\text {a }}$ série, como você se sentiu?

$\mathrm{R}=$ NO INICIO, APREENSIVA, POIS NÃO TINHA NENHUM PREPARO PARA ALFABETIZAR UMA ALUNA COM SURDEZ. MUITO MEDO DE NÃO CONSEGUIR ALFABETIZÁ-LA. TIVEMOS MUITAS DIFICULDADES SIM, NOS DITADOS, NAS INTERPRETAÇÕES, MAS VENCEMOS TODAS ESSAS DIFUCULDADES, FOMOS NOS ADAPTANDO, E SUPERADO TODAS AS DIFICULDADES.

4- Como foi sua experiência de ensino?

$\mathrm{R}=\mathrm{A}$ MELHOR EXPERIÊNCIA DA MINHA VIDA PROFISSIONAL.

5_ houve momentos de angústia, pesquisa, sucesso e/ou ajudas recebidas?

$\mathrm{R}=$ SIM, PORQUE EU ACHAVA QUE O MÉTODO NÃO ERA ADEQUADO PARA UMA ALUNA COM ESSE PROBLEMA.ERA TODO SILÁBICO E, COM SOM MUITO PARECIDO.ELA CONFUNDIA NA HORA DA PRONUNCIA, NOS DITADOS, COMO POR EXEMPLO, M COM B, T COM D E ASSIM POR DIANTE. (CIDA, 2015, corpus de pergunta, anexo 2)

Em todos os momentos, minha vivência foi baseada na construção das visões, pois não conseguia ouvir nada, tudo para mim eram "as apontações dos dedos". Eu via minha mãe apontar uma imagem juntando a letra, a leitura labial, eram várias tentativas; minha percepção conseguia entender quando colocava em prática social, ou seja, a imagem deveria estar ligada

\footnotetext{
${ }^{22}$ Nome fictício para preservar a identidade.
} 
na escrita. Palavras com significados eu demorava a entender, pois precisava de ações. Minha linguagem só foi possível através de muitas vivências sociais baseadas na visualidade. Toda ação que minha mãe e minha professora que também participou na construção da minha linguagem foram momentos de muita prática social, pois se comportavam como sistemas vivos, ou seja, que se reproduziam como forma de readaptação para a minha nova existência de pessoa surda. Em minha vida, "uma ação me serve como discurso" (LABORIT, 1994). Portanto, como diz Santaella "todo e qualquer fato cultural, toda e qualquer atividade ou prática social constituem-se como práticas significantes, isto é, práticas de produção de linguagem e sentido".

Para melhor compreender os fatos e as ações de práticas sociais para a aquisição de linguagem apresento um exemplo na figura 5, da minha época de $1^{\mathrm{a}}$ série do ensino fundamental, em 1987, em que mostra as produções feitas pela professora, as apontações e também mostra as imagens com a ajuda de minha mãe:

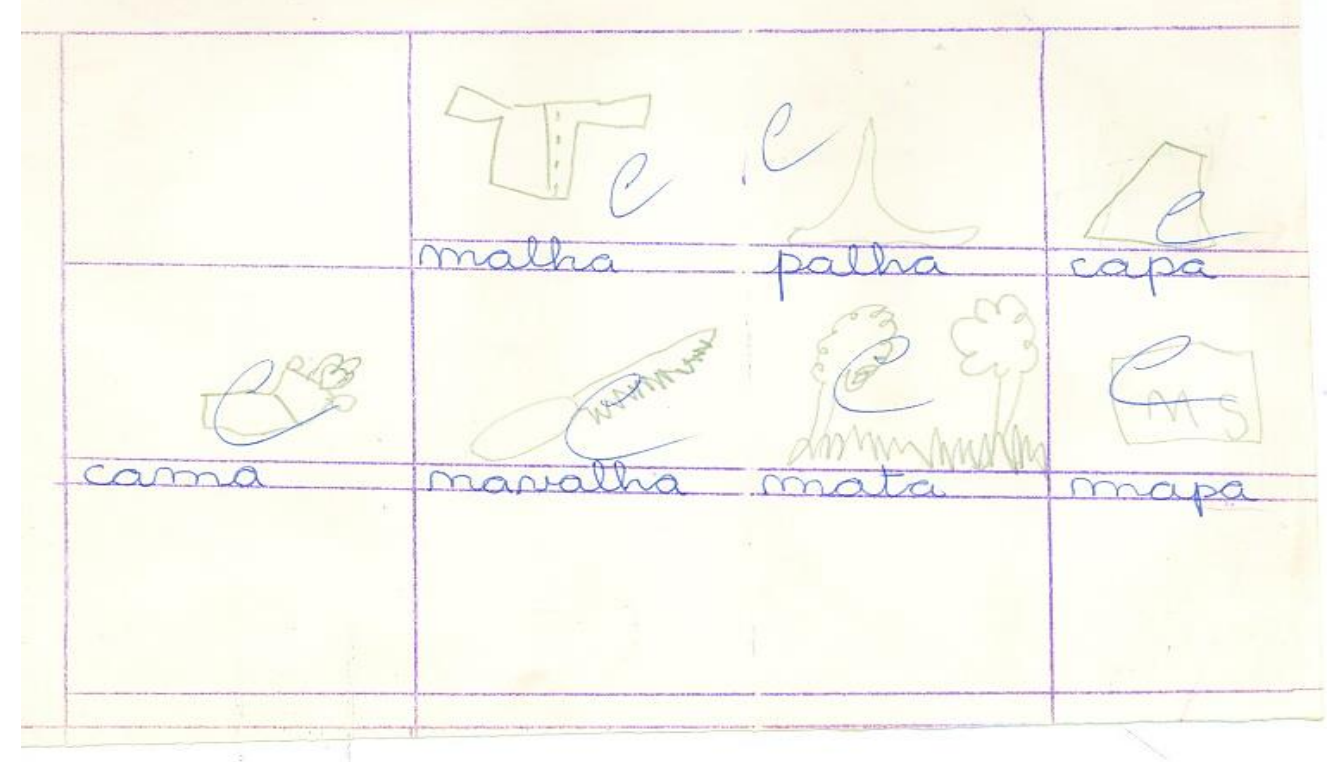

Figura 7 - Atividade de $1^{\text {a }}$ série - Ana Paula - 1987

Estas figuras mostram que as imagens e palavras, além das apontações, eram constantes, como práticas copistas, e que todos os dias precisava memorizar a imagem e a escrita. Constantemente minhas tarefas eram apenas essas práticas de memorização, além da participação da minha mãe, como colaboradora no sentido mediador dos conceitos de signo e significado. Eu demorava ainda mais para entender as palavras, elas só foram produzir sentidos quando depois de muita repetição, eu precisava vivenciar a ação. E toda ação pode 
ocorrer através de imagem, filmes ou observações feitas no convívio social de um local ou tempo.

Nessas singularidades é onde eu vejo meu lugar no mundo, porque nesse lugar eu sou a única que posso ver e interpretar meus conhecimentos de mundo, através dos conjuntos de circunstâncias vivenciadas no ambiente social em que vivi. Todos os outros só poderão me entender quando existe um estímulo resposta para os outros indivíduos externos. Como afirma Bakhtin (2011, pag. 21):

\footnotetext{
Esse excedente da minha visão, do meu conhecimento, da minha posse - excedente sempre presente em face de qualquer indivíduo - é condicionado pela singularidade e pela insubstitutibilidade do meu lugar no mundo: porque esse momento e nesse lugar, em que sou o único a estar situado em dado conjunto de circunstancias, todos os outros indivíduos estão fora de mim. (BAKHTIN, 2011, pag. 21)
}

Ainda sobre a figura do meu caderno de caligrafia, entre o sentido da escrita e da palavra, apesar das duas representarem uma imagem, ambas possuem sentidos diferentes. A escrita representa o ícone de Peirce, a imagem pictórica representativa. A palavra representa o sistema de Saussure, ou seja, o sistema da língua. Escrita e palavra, ambas são linguagens. Essas linguagens estão dentro de nós como sentimento, vontade e conhecimento.

Davallon (2015) fundamenta bem essas diferenças buscando em Benveniste dois modos de significação, em que eu compreendo sobre as diferenças da escrita e da palavra:

\footnotetext{
Sabemos desde o artigo em muitos aspectos fundador de E. Benveniste, aparecido em Semiótica em 1969 que existem dois modos de significação: um semiótico fundado sobre o reconhecimento de unidades de significação previamente definidas (eu reconheço o sentido das palavras), o outro semântico e meta-semântico, fundado sobre a compreensão do sentido do texto em sua totalidade (eu compreendo o sentido conjunto de uma frase, por exemplo) e que inclui os mecanismos da enunciação. Benveniste adianta que a imagem funciona antes de tudo sob o modo semântico e que ela não pode conjugar os dois modos de significação (somente a língua poderia operar essa conjunção). (DAVALLON, 2015. pag.27-28)
}

$\mathrm{Na}$ minha visão sobre as diferenças entre a palavra e a escrita, busco analisando Lótman (1979) e Saussure (2012), onde ambos retratam a beleza do texto, da escrita e da palavra. Quando observo o conceito da palavra, ela é um representante das línguas naturais que, por sua vez, representa o signo como um sistema linguístico. Para Saussure (2012, pag. 106): "o signo linguístico une não uma coisa e uma palavra, mas um conceito e uma imagem acústica". A palavra engloba todo o sentido que um signo carrega para representar uma parte da linguagem, onde a língua faz seu uso como produto social mediado dentro de uma 
comunidade. A comunidade que entendo aqui pode representar desde uma simples família até um grupo cultural.

Assim como para Lótman (1979), eu considero as palavras como signo e esses signos se tornam um texto:

Nas línguas naturais distinguem-se com uma relativa facilidade signos - unidades constantes, invariantes do texto - e regras sintagmáticas. Os signos diferenciam-se nitidamente em planos de conteúdo e da expressão, entre os quais existe uma relação de independência mútua, de convencionalidade histórica. Num texto artístico verbal, não só os limites dos signos são diferentes, mas o próprio conceito de signo é diferente. (LÓTMAN, 1979, pag. 55)

A escrita é por mim representada como ícone, mesmo que a palavra seja uma imagem gráfica; a escrita está intimamente ligada a um ícone. O que entendemos por ícone Santaella (1979), dialogando com Peirce anailisa os modos como o fenômeno reage sobre a percepção da imagem gráfica da escrita. Esses níveis de percepções estão ligados intimamente em nosso interior. De acordo com Lótman (1979, pag. 56):

Os signos icônicos constroem-se segundo o princípio de uma ligação de dependência entre a expressão e o conteúdo. É por essa razão que a delimitação dos planos de expressão e do conteúdo num sentido habitual para a linguística estrutural torna-se geralmente difícil. O signo modeliza seu conteúdo. Compreende-se que nestas condições se produza num texto artístico uma semantização dos elementos extra-semânticos (sintácticos) da língua natural. (LÓTMAN, 1979, pag. 56)

A escrita se torna uma consciência imediata, tal como nas categorias de Peirce, a primeiridade. A escrita torna-se, conforme Santaella (1979, pag. 09): "uma qualidade da consciência imediata", ou a pureza e a qualidade do ser e sentir. Tudo que está presente em sua consciência - a imagem - se torna uma ligação tão íntima em seu interior que provoca uma sensação de séries inconstantes e memórias de linguagens provocadas por ações dos discursos. É o incitar do instante em que a escrita provoca em você a sensação da vivência como ser humano:

As interferências são internas, isto é, as que vêm das profundezas do nosso mundo interior, e externas, as que dizem respeito às forças objetivas que atuam sobre nós. Essas forças vão deste o nível das percepções que, pelo simples fato de estarmos vivos, nos inundam a todo instante, até o nível das relações, interpessoais, intersubjetivas, ou seja, as relações de amizade, vizinhança, amor, ódio etc, encontrando ainda as forças sociais que atuam sobre nós: as condições reais de nossa existência social, isto é, as relações formais de classes sociais que variam de acordo com as determinações históricas das sociedades em que se vivem. (SANTAELLA, 1979, pag. 9) 
Neste momento em que uso a escrita ela provoca em mim reconhecimento do meu pensamento em tornar-se a palavra em algo concreto. Enfim, a palavra se torna concreta através da escrita e é a escrita que vai materializar meus pensamentos. Sobre o fato de que existem as fronteiras entre os mundos ouvintes e surdos, a escrita se torna a ponte entre as relações destes dois mundos e a relação da palavra com a escrita é a relação íntima entre os dois mundos, é onde eu mais exploro em deduzir minhas palavras para induzir a escrita para o outro.

Então, como eu aprendi a reconhecer a escrita e a palavra? Como foi possível que essas ligações tão íntimas me provocassem uma sensação de união entre os dois mundos diferentes? Pode parecer surreal estas perguntas, mas elas têm uma explicação clara nas teorias científicas da neurociência e também na neurolinguística.

Antes de mais nada deixo claro que nasci ouvinte e me tornei surda aos 3 anos. Há uma característica muito diferente dos que nascem surdos, pois estes tem uma experiência diferente dos outros que adquiriram depois. ${ }^{23}$

Nas minhas memórias de percepções eu me via e me observava todo meu redor através dos meus olhos, toda visualidade era minha riqueza. Eu percebia o som apenas nos meus sentidos táteis e também visuais, via que as bocas das pessoas soltavam um som ${ }^{24}$, porém sons muitas vezes sem significado para mim. Achava engraçado ou achava bonito, assim como músicas, as músicas de sons bastantes graves. Mas para mim isso era tudo sem significado. Sentia em mim um vazio interior, uma solidão mesmo que minha família estivesse sempre presente me sentia como se faltasse algo. Achava que eu era a única pessoa surda e sempre ficava triste ao ver outras crianças brincar de corre-corre, cantigas de rodas, esconde-esconde sempre ganhavam e eu sempre perdia. Muitas vezes não era convidada, ficava sempre no balanço a brincar sozinha, observando e observando. Alguns de meus amigos sempre puxavam meus braços e mãos para segui-los. Não conseguia entender para onde estávamos indo, só depois de me mostrar o lugar, mandar eu fazer isso e aquilo, ou seja, "me copie" é que eu participava. Precisei treinar muitas brincadeiras para então brincar de verdade.

\footnotetext{
${ }^{23}$ Para melhor entender esse mundo, sugiro o livro "Vendo Vozes" do escritor Oliver SACKS, nas páginas 17 a 40.

${ }^{24}$ Adquiri a surdez aos 3 anos de idade depois de uma doença(meningite), é normal que haja memórias de som, pois dentro da criança há uma linguagem guardada nela. Mas deixo claro que são diferentes entre um surdo nasceu surdo é muito diferente de quem adquiriu a surdez em outra fase. Para melhor esclarecimento, o livro “Aquisição da Linguagem” de Ronice Miller de Quadros, explana bem essas diferenças.
} 
Há um artigo bastante interessante de uma pesquisa com ressonância magnética funcional sobre surdos bilíngues de Valadão, Issac, Rosset, Araújo e Santos ${ }^{25}$ (2014) sobre a elaboração da linguagem. Através deste artigo foi possível que os surdos, mesmo os que adquiriram surdez após um período de aquisição de som, tivessem mais afinidade com a visualidade,proporcionando-lhes melhor compreensão e assimilação dos significados dos signos. É desta forma que eu pude compreender e assimilar o mundo exterior, através da visualidade. É estranho,mas para mim, consigo entender melhor baseados sempre na visualidade. A leitura labial é uma visualidade, mas uma leitura sempre fragmentada, sempre faltava algo para compreender o sentido e enunciado da frase.

Na figura 6, minhas tarefas diárias eram sempre nos modelos de repetição e práticas, buscando sempre memorizar a imagem e as escritas. Eu tinha que estar sempre a treinar, desenhava e escrevia praticamente em todas as aulas. Quando eu tinha dúvidas ao ver uma escrita nova, eu perguntava à minha mãe. Ela sempre paciente buscava diversos recursos visuais além da leitura labial para eu conhecer a palavra. Por exemplo, a escrita "palha" era muito idêntica à escrita "malha", minha mãe teve que achar a palha e a malha e me mostrou apenas isso, "isto é palha, isto é malha”, então desenhava. Precisava decorar a escrita e a imagem para então saber as diferenças. Mas, e as palavras "malha" e "palha"? O significado? Só vinha depois que minha mãe me mostrava a realidade onde adquiria a experiência e a vivência.

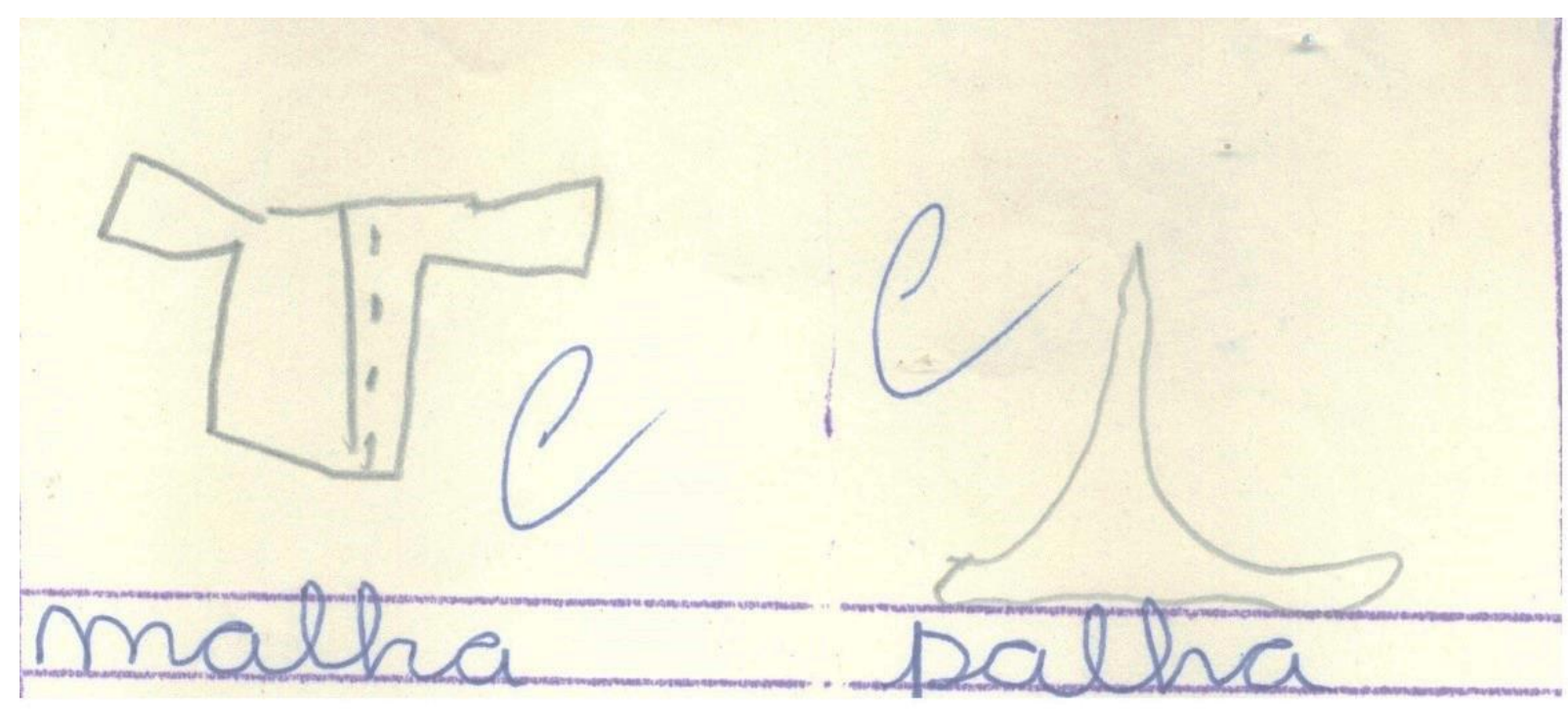

Figura 8 - atividades diárias - Ana Paula - 1987

${ }^{25}$ RBLA, Belo Horizonte, v.14, n.4, pag. 835-860, 2014 - <http://dx.doi.org/10.1590/1984-639820145554>. 
Essas percepções deram-me o direito à existência real, comum a todos.Mesmo com a ausência de som eu podia ter a percepção de mundo, pois minha mãe foi meu modelo. Para considerar essas percepções, Merleau-Ponty reflete sobre a percepção da existência entre o eu e o outro, como formas que adquiramos a linguagem:

\begin{abstract}
Se considerar minhas percepções como simples sensações, elas serão privadas, serão somente as minhas. Se as tratar como atos de inteligência, se a percepção for uma inspeção do espírito, e o objeto percebido, uma ideia, então será do mesmo mundo que falamos, vocês e eu, e a comunicação entre nós será de direito, porque o mundo terá passado à existência ideal e porque ele será o mesmo em todos nós, tal como o teorema de Pitágoras. Mas nenhuma dessas duas formulas dá conta de nossa experiência. (MERLEAU-PONTY, 2015. pag. 38)
\end{abstract}

Dessa forma, minha mãe era o meu ato de vivência diária, além da minha professora Cida; eu sempre buscava orientações na minha mãe para poder compartilhar um trabalho de linguagem. Não é à toa o que minha mãe diz sobre a professora Cida: “Aos 7 anos, entrou no $1^{o}$ ano (antiga $1^{a}$ série do $1^{\circ}$ Grau) a professora Cida Nabuco (minha deusa!). Tudo o que ela é hoje eu devo a ela". A simbologia "Deusa" se refere à concepção de pessoa que buscou o trabalho de modo a melhorar as práticas de aquisição da linguagem, algo que era constantemente cobrado à época. Este termo foi usado porque a professora Cida não tinha conhecimento de como ensinar uma criança surda. Era o $1^{\circ}$ ano da professora Cida. A professora buscava a única ajuda através da minha mãe. Ambas são professoras de $1^{\circ}$ ano, ambas tinham dúvidas em relação a como construir a comunicação comigo.

Durante o ano de 1987, segundo uma conversa com minha mãe sobre o método de ensino daquele ano, existia um plano de cobrança sobre a alfabetização de crianças pelo método Sodré. O governo havia solicitado colocar em prática. Mas houve dúvidas quanto ao método, já que o mesmo utilizava muito a prática da oralização e memorização das escritas.

As palavras só eram construídas através das frases. Ou seja, as frases se tornam o significado de cada palavra aprendida. A Professora Cida questionou esse método: "Porque eu achava que o método não era adequado para uma aluna com esse problema. Era tudo silábico e, com muito som muito parecido. Ela confundia na hora da pronúncia, nos ditados, como por exemplo, $M$ com B, $T$ com $D$ e assim por diante”. Com toda a razão, o método Sodré tinha como meta o treinamento auditivo e perceptivo no método analítico.

Pela minha percepção, a linguagem foi construída através das ações e práticas dessas duas pessoas (Mãe e Professora Cida). Procuravam sempre relacionar as imagens, as "apontações" com a escrita. Toda minha comunicação foi construída visualmente buscando transformar a oralidade em algo de objeto concreto visual. Não me lembro nada de "ouvir" 
um só som. Só tenho memórias visuais. Tudo é relacionado às constantes ações de construir conceitos e vocábulos através do signo imagem. Durante uma prova, é possível haver confusão visual, pois a escrita se tornou um ícone com proximidade com outros ícones da escrita. Um exemplo disso é a figura 7, onde percebe-se que "mala" e "malha" são escritas idênticas.
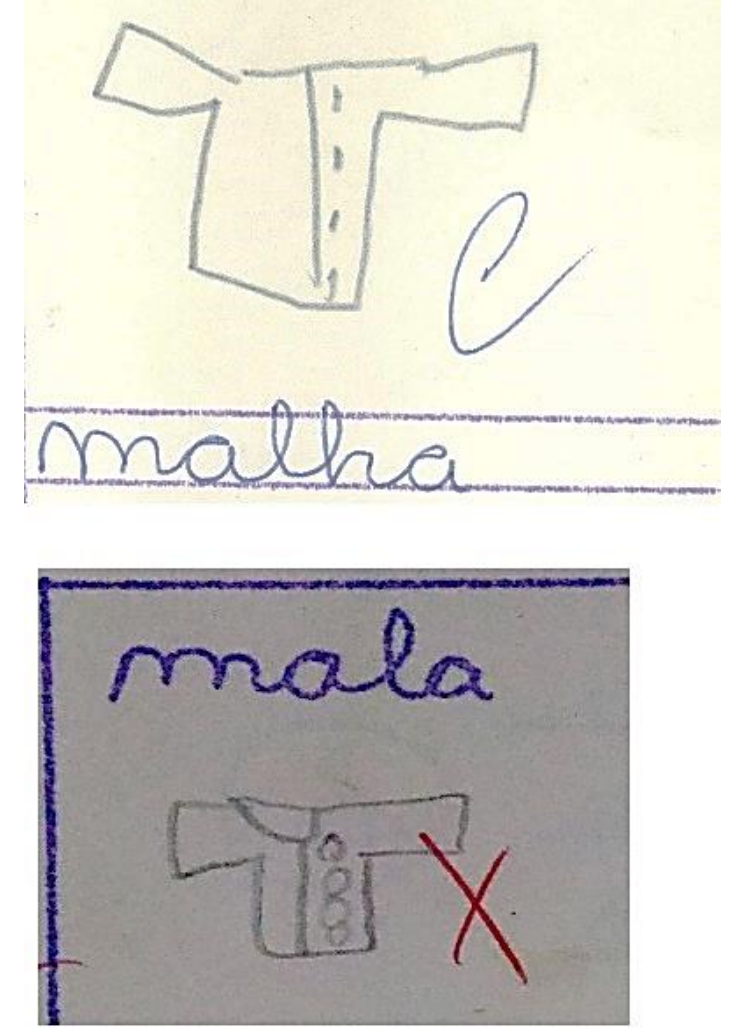

Figura 9 - Atividade de avaliação -Ana Paula - 29 de junho de 1987

A percepção dos diferentes signos citados na figura 7 influencia, como explica Lótman, sobre o conceito de signo representativo verbal (a imagem) em que o sistema modelizante visual, neste caso a escrita, só pode estar ligado se o conhecimento foi adquirido anteriormente, ou seja, o sujeito precisava ter um conhecimento das relações dos ícones idênticos para exemplificar as diferenças. Portanto, faltou-lhe representar as imagens e mostrar que os diferentes ícones possuem similaridades na escrita. Isso é algo natural em toda sociedade que reconhece a distinção da escrita tanto pelo conhecimento adquirido quanto pelo conhecimento vivenciado. Assim, para Lótman (1978, pag. 111), sobre o fato de não reconhecer as diferenças seria: 
O signo como fonte de informação não se torna menos facilmente um meio de desinformação social. A tendência da luta contra a palavra, a tomada de consciência de que a possibilidade de engano toma raiz na sua própria essência, é um fator tão constante da cultura humana como a admiração da força da palavra.

Minha língua, minha comunicação foi construída simbolicamente pelas imagens. O assujeitar da minha relação com o outro mundo ouvinte se deu em função do espaço da memória e estar sujeita aos fatos do acontecimento. Essa memória me torna como um sujeito observador do tempo e espaço, pois "nosso tempo vivido corre sem fim e sem retorno, esta é a experiência comum" (BENVENISTE, 1989, pag. 71). Então, para Benveniste, nossa vida tem pontos de referências que nos tornam sujeitos com domínio de linguagem e língua, pois:

\begin{abstract}
O observador, que é cada um de nós, pode lançar o olhar sobre os acontecimentos realizados, percorrê-los em duas direções, do passado ao presente ou do presente ao passado. Nossa própria vida faz parte desses acontecimentos, que nossa visão percorre uma direção ou em outra. Neste sentido, o tempo crônico, congelado na história, admite uma consideração bidirecional, enquanto que nossa vida vivida corre (é a imagem percebida) num único sentido. A noção de acontecimento é aqui essencial. (BENVENISTE, 1989, pag. 71)
\end{abstract}

Diante de todo a experiência de percepções da minha infância, eu não posso afirmar que minha percepção seja igual a outras crianças e adultos surdos. Cada surdo é único. Cada surdo tem sua própria vivência, sua forma de observar, sentir e construir cada momento que vê a percebe as coisas e fatos. Muitas experiências fenomênicas surdas são baseadas no foco visual. Então, Marques (2008, pag. 65) nos elucida sobre a percepção do corpo, onde cada experiência é única podendo ser apenas o sentido de compreender o outro corpo:

\begin{abstract}
A investigação do que proporciona a experiência de ser surdo me parece mais sustentável do que as "representações" que ela produz; o que lhes confere a possibilidade de construir estas experiências só podemos descreve-las a partir de uma observação do corpo, a "experiência visual" passa a ser apenas um entre os vários aspectos e, mesmo assim, ela mesma se desprende em diversas partes a serem investigadas. Pois "[...] só posso compreender a função do corpo vivo realizando-a eu mesmo e na medida em que sou um corpo que se levanta em direção ao mundo".(MARQUES, 2008, pag. 65)
\end{abstract}

Podemos também fazer uma nova observação sobre a figura a seguir analisando-a sobre a questão dos erros e percepção com um olhar do surdo: 


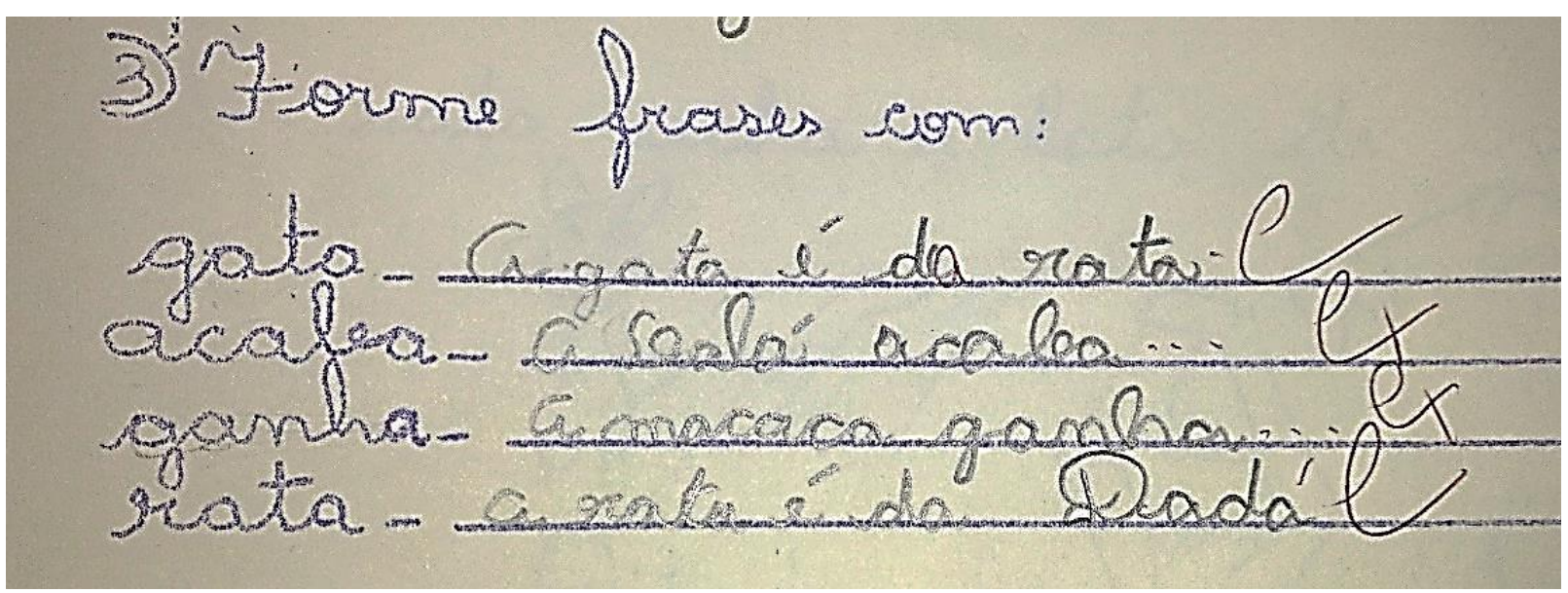

Figura 10- atividade prova - Ana Paula - 23 de junho de 1987

Aqui nesta figura 8 observamos "meio certo" das seguintes palavras: ACABA e GANHA. Estas são palavras representadas como verbos. Como se pode observar a frase "A LALÁ ACABA..." falta um complemento ausente para então finalizar a frase. Neste caso, como pessoa surda, nesse olhar, temos o sentido de que o verbo ainda é difícil de ser assimilado, pois como posso observar, eu apenas estava memorizando nomes, portanto ainda não sabia a função verbo. Eu não tinha conhecimento do verbo, mas na minha percepção eu vejo o verbo como um nome, uma palavra. Era a prática da memorização, por esse sentido não foi possível reconhecer o verbo.

As palavras e as escritas provocaram em mim, dupla relação que se torna entre esses dois conceitos e se deixa a apreender no corpo. Podemos explanar através da Semiótica da Cultura que as palavras e as escritas tornam o texto visual cercado de signos arbitrários que só se podem tornar sentido se as linguagens de mundo já tenham sido assimiladas. Nisso "cada um desses sistema semiótico gera constantemente problemas que precisam ser revistos, reordenados e compreendidos" (MACHADO, 2003. pag.24).

\subsection{Me vendo o corpo como "deficiente"}

Minha adolescência, assim como a de muitos jovens, foram de descobertas de um novo corpo, de um olhar para si mesmo e a construção da identidade. Foi um dos momentos em que eu tive que refletir sobre o eu como 'deficiente auditiva", a colocar diante de mim questões sobre o porque sou diferente? Porque as pessoas se afastam de mim? O que elas estão falando? Sobre o que que estão falando? 
Busco o curpus de Emmanuelle Laborit (1994) para bem detalhar a vivência surda que foi minha época. Lembro-me que me considerava uma "deficiente", não tinha noção do que era cultura e identidade surda. Tinha conhecimento de que os deficientes auditivos tinham poucas oportunidades na vida como ter um emprego, fazer faculdade. Na minha família, eu observava meus familiares conversando com meus primos sobre faculdades, todos tinham que ter uma carreira promissora como advogado, médico engenheiro civil. Eu me via "incapaz" de realizar, mas tentava o melhor de mim. Eram lutas constantes na escola para entender cada leitura labial de cada professor. Não era nada fácil, me perdia constantemente. E claro, a sensação de solidão era uma coisa muito normal para mim, ora me irritava, ora me tranquilizava.

\footnotetext{
Vivia no silêncio porque não me comunicava. É esse o verdadeiro silêncio? A negritude completa do incomunicável? Para mim, o mundo inteiro era negro silêncio, a não ser por meus pais, sobretudo minha mãe.

O silêncio tem, pois, um sentido exclusivamente meu, o de ser a ausência de comunicação. Em outras palavras: nunca vivi no silêncio completo. Tinha meus barulhos pessoais, inexplicáveis para quem escuta. Tenho minha imaginação, e ela tem seus barulhos em imagens. Imagino sons em cores. Meu silêncio tem, para mim, cores, nunca é preto ou branco.

Os barulhos dos que escutam também são imagens para mim, sensações. A onda que rola sobre a praia, calma e doce, é uma sensação de serenidade, de tranquilidade. Aquela que se enriça e se precipita com as costas lançadas para o alto, é a cólera. O vento são os meus cabelos que flutuam no ar, o frescor ou a doçura sobre minha pele. (LABORIT, 1994, pag. 19-20)
}

O que é o silêncio? Assim como Laborit, eu me perguntava o que era mesmo o silêncio. Havia em minha percepção de que o silêncio representava a escuridão, a solidão, a falta de comunicação. O sentido de "negritude do silêncio" se equivale a falta de comunicação entre os dois mundos surdos e ouvintes. Neste texto, Laborit está representando uma imagem sobre a barreira em que dois mundos diferentes podem representar. São culturas totalmente diferentes mesmo vivendo no mesmo ambiente. "Meus barulhos pessoais" são as próprias linguagens de comunicação única onde representamos nossa percepção através das imagens. Em minha época de adolescência havia muitos barulhos, sons, mas todos eram insignificantes. Não existia para mim um significado, um texto não-verbal que me traduzia.

Neste texto nos detivemos na representação da Semiótica da Cultura de Lótman, onde o texto de Laborit simboliza bem essa representação da cultura surda marginalizada. Minha representação na adolescência se passava por uma "negritude de silêncio" por não saber o sentido e significado das coisas e fatos. O tempo todo tinha dúvidas, precisava de respostas, entender o que estavam falando. Em uma conversa de grupo, todos falavam ao mesmo tempo, 
era impossível ler os lábios. Outra vez a negritude do silêncio se pairava em meu convívio social.

Estamos diante de corpus de discursos surdos que reflete sobre o tempo e o espaço. Pierre Desloges (1779) também reflete sobre a falta de língua e comunicação. Desloges fala de um discurso de subjetividade surda em relação à sensação da falta da língua de sinais. Padd (2015) nos mostra Desloges, no livro "The deaf experience" de Harlan Lane e Frankilin Philip, sobre sua subjetividade de "negritude do silêncio", o mesmo que se retrata por mim e Laborit:

\begin{abstract}
Enquanto eu vivia separado de outros Surdos, o único recurso que usava para me expressar era a escrita ou a minha pobre pronúncia. Durante muito tempo não estava desperto para a língua gestual. Usava gestos dispersos, isolados, sem ligação [...] Mas as coisas são muito diferentes para os Surdos que vivem numa grande cidade, em Paris por exemplo... num teatro como esse, as nossas ideias desenvolvem-se e quando o homem surdo isolado chega, ele aprende a polir e a ordenar os seus gestos [...] Ao conviver com seus companheiros, aprende rapidamente a arte de retratar os seus pensamentos, mesmo os mais abstratos ... Não há acontecimento em Paris, em França, ou nos quatro campos do mundo, que esteja fora do alcance da nossa discussão. Expressamo-nos sobre todos os assuntos com tanta ordem, precisão e rapidez como se ... tivéssemos a faculdade da fala e da audição. (PADD, 2015. pag.63. In Lane e Philip, 1984, pag.34-6)
\end{abstract}

A Semiótica da Cultura nos explica que quando se introduz no campo do conhecimento científico ao se pensar o texto, neste caso os corpus, "como sendo construído por inúmeros subtextos e em permanente diálogo com vários outros" (TOCHI, 2014, pag.55) $)^{26}$, a noção de texto acima coincide com as experiência de Laborit, Desloges e meu relato, trazendo-nos retratos de textos de significação da vivência do fenômeno de Ser Surdo, trazendo consigo as três funções do texto, segundo Lótman: 1 - a função comunicativa; 2 - a função geradora de sentidos; e 3 - função mnemônica. Todas essas funções de textos nos provocam as representações das linguagens dos surdos e é a mesma da "negritude do silêncio" quando não nos encontramos com a língua de sinais. Assim mesmo ocorreu em minha vivência de pessoa surda, quando não reconhecia a identidade e cultura surda eu vivi a adolescência no estereótipo de Deficiente Auditiva.

Segundo Marques (2008, pag. 65), expõe que ser surdo é a experiência do corpo próprio, onde as "representações" são manifestação corpóreas de uma nova significação de mundo. 


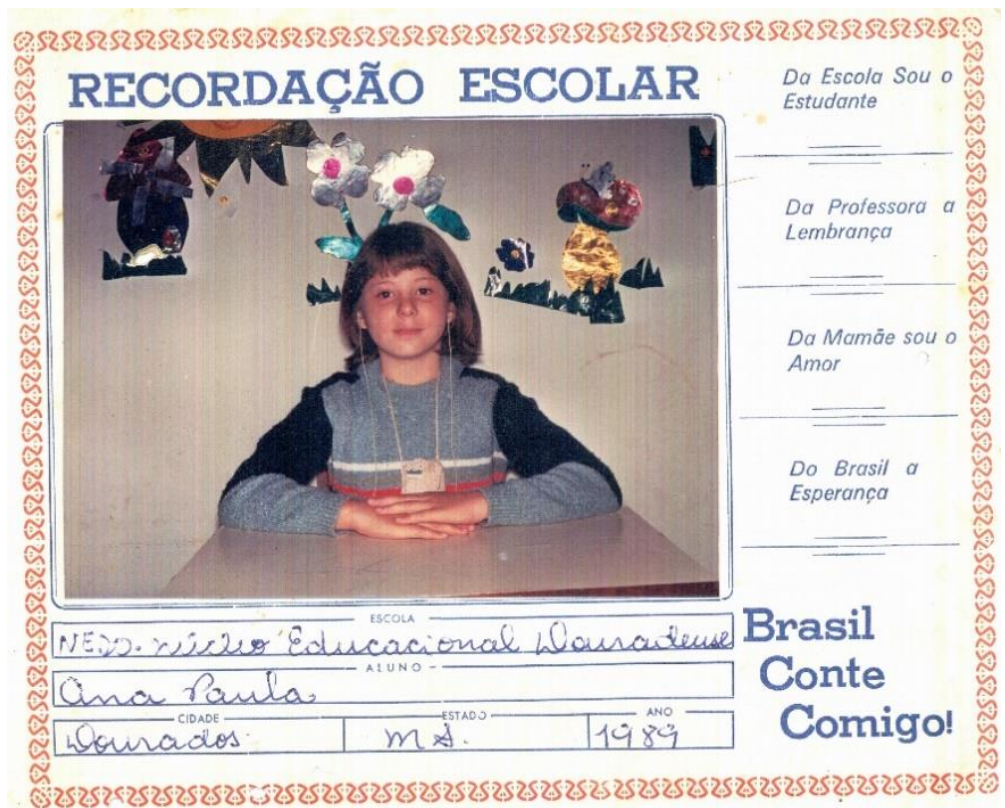

Figura 11 - A imagem do aparelho auditivo mostrava a minha imagem de pessoa deficiente auditiva

Dessa maneira, em minha adolescência me via cercada de uma identidade em que me reconhecia como um corpo "deficiente", limitado. As leituras labiais passaram a ficar cada vez mais difíceis de assimilar, ficaram fragmentadas e incompletas. Minha audição, com o passar dos anos, aumentava mais a surdez, fazendo com que necessitava prestar mais atenção e observar mais a visualidade. Eu poderia ter acesso ao mundo externo através da escrita, ou também das constantes observações das ações corporais, ou seja, expressões corporais das pessoas, inclusive os comportamentos. Vale lembrar, nesta dissertação, que o conceito de texto, segundo Lótman, é o mesmo conceito que procurava entender através do corpo expressivo das pessoas. Muitas pessoas à época, quando eu não compreendia uma fala através da leitura labial, seu corpo com as apontações, mais as expressões, ajudavam-me a entender a fala. Por isso, o corpo expressivo é também, neste caso, um texto, uma fala, uma palavra.

Diante dos fatos, tive uma experiência maravilhosa de ser aceita e inserida na comunidade ouvinte, foi quando me ingressei num grupo de teatro, chamado Cia de Teatro Camaleão:

Fato interessante aconteceu que havia um professor de língua portuguesa, por sinal excelente professor e que usava barba a muitos anos e a Ana Paula não conseguia ler os lábios por causa da barba. Foi onde o professor tomou a dura decisão de tirar a barba, nessa grande atitude, os outros professores que também usava fizeram o mesmo, e assim beneficiou não só a Ana Paula, mas todos os alunos, não só esse gesto, mas os professores aprenderam que não deveriam andar na sala, explicando conteúdo e sim ficar parados na frente dos alunos e articulando as palavras. O desempenho dos alunos foi muito significativo, para a surpresa dos professores. Nessa época começou a fazer teatro, inclusive participou de várias peças: 
Fantasminha, A Bruxinha que era boa, com a professora Gicelma. (MARIA DE FÁTIMA, 2015, corpus, anexo 1)

Apesar de minha mãe ter falado sobre um professor que tirou a barba para eu poder ler os lábios, isso só contemplou melhor meu entendimento apenas em alguns momentos. As aulas de português eram terríveis de compreender, mesmo com o ótimo professor. Cada aula que tratava de sintaxe, de orações subordinadas, predicados e outros eu não conseguia assimilar. Eram frases que eu não percebia nada sobre as falas orais, através das leituras labiais. Eram estranhas, incompreensíveis, pois não conseguia visualizar o concreto dessas práticas. Eu me perguntava: por que esse é o sujeito? Por que esse é o predicado? O que uma palavra no final da frase tem a ver com a palavra inicial da frase? No quadro negro, o professor de português desenhava muito as frases com apontações e colocações das nomenclaturas das orações subordinadas. Via o corpo dele sempre a expressar para tentar chegar a um entendimento da aula. Algumas vezes eu pude compreender apenas ele simplificando a frase, mas no sentido escrito desenhado e expressivo com o corpo. O que me fez a diferença desse professor ter uma constante luta para eu entender suas aulas é que ele era realmente expressivo com o seu corpo, uma parte natural dele mesmo, não necessitando fazer pedidos para que mude o comportamento. O corpo - texto - já era uma parte do professor mesmo.

A época em que ingressei no teatro me marcou muito. Gostava muito de me representar em personagens, principalmente animais, pois meu corpo representava muito bem as expressões corporais. Assim como explanei o texto visual, no teatro eu pude mostrar a fala e a comunicação através do corpo. Conseguia a comunicação através da expressividade do corpo.

Fiz parte de um grupo chamado de "CIA de TEATRO CAMALEÃO”, um grupo formado por jovens que tinha sempre um ideal: o amor pela amizade e pelo teatro. A CIA faz parte do núcleo de teatro da FUNCED em 1995-1996. Este grupo teve apresentações que marcaram a história de Dourados. Em 29 de outubro de 1996, a maior apresentação do grupo se marcou com a peça "A bruxinha que era boa" de Maria Clara Machado. Este dia teve recorde de público, pois necessitou em duas apresentações, para que quase mil pessoas puderem prestigiar o evento. Foi um dos momentos mais marcantes de minha vida. ${ }^{27}$

Nessa apresentaçãos de teatro, ocorrida em 1996, uma mãe que assistiu à peça de teatro "A bruxinha que era boa", no qual eu interpretava a "Bruxaruga", uma espécie de

\footnotetext{
${ }^{27}$ Em anexo, tem uma página do jornal "O Progresso”, conta bem essa história.
} 
metade-bruxa, metade-tartaruga, perguntou para mim no final da apresentação "Porque você fala e tem uma voz diferente? ". Eu respondi que sou deficiente auditiva, logo ela explanou: “Que milagre! Uma deficiente que fala!". Aquele discurso me estranhou pois não sabia que havia outros surdos ou deficientes auditivos. Este fato nos lembra também da história dos surdos em que o surdo era usado como instrumento de milagres, pela passagem da bíblia, que reconhece "a exaltação bíblica da voz e do ouvido como único e verdadeiro modo como o homem pode falar com Deus" (SACKS, 2010, pag. 25). É nesse sentido, a experiência fenomênica de ser surda, naquela época sem identidade surda, que me fez refletir sobre a condição de ser "deficiente auditiva falante", era um privilégio religioso.

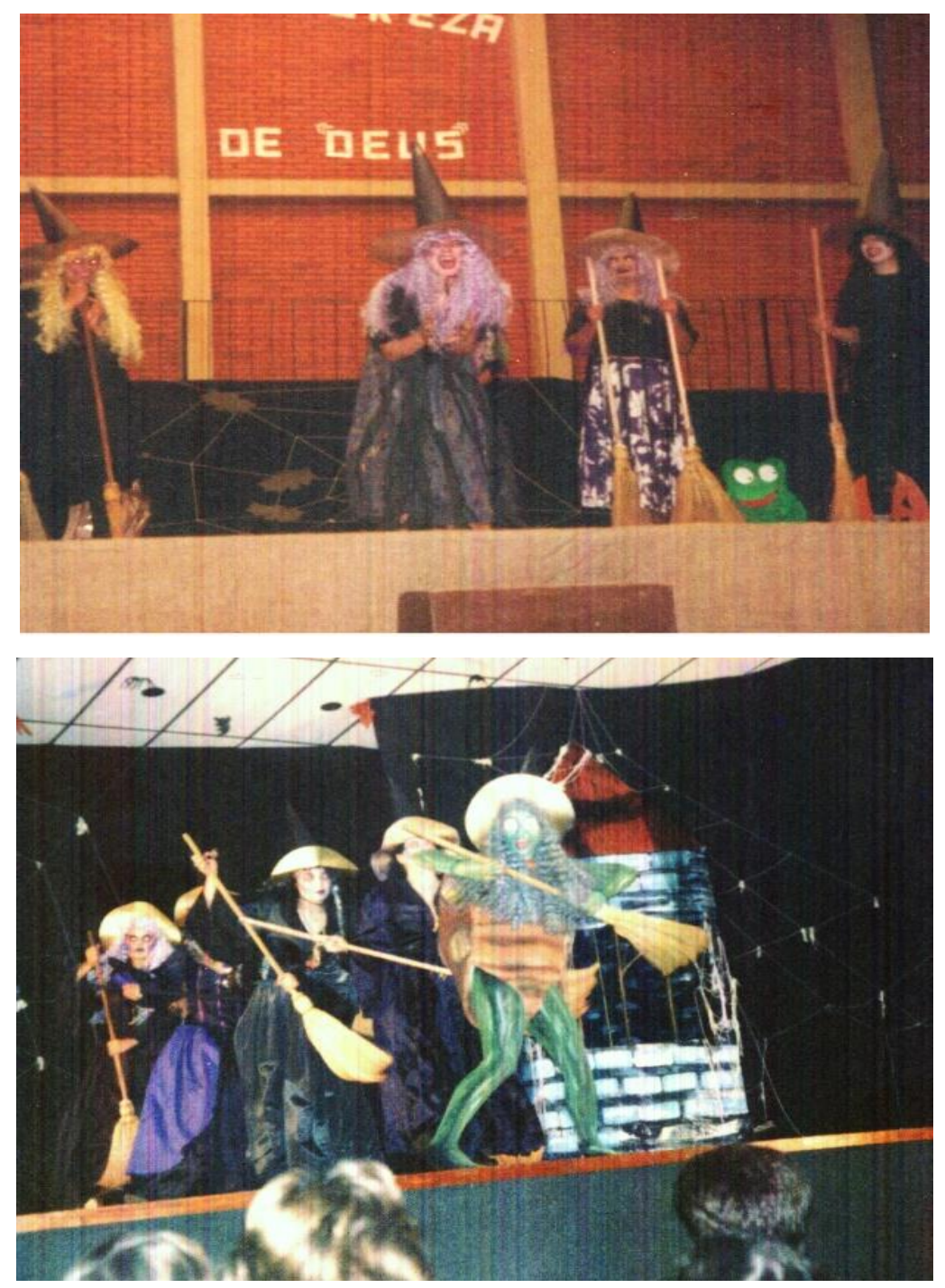




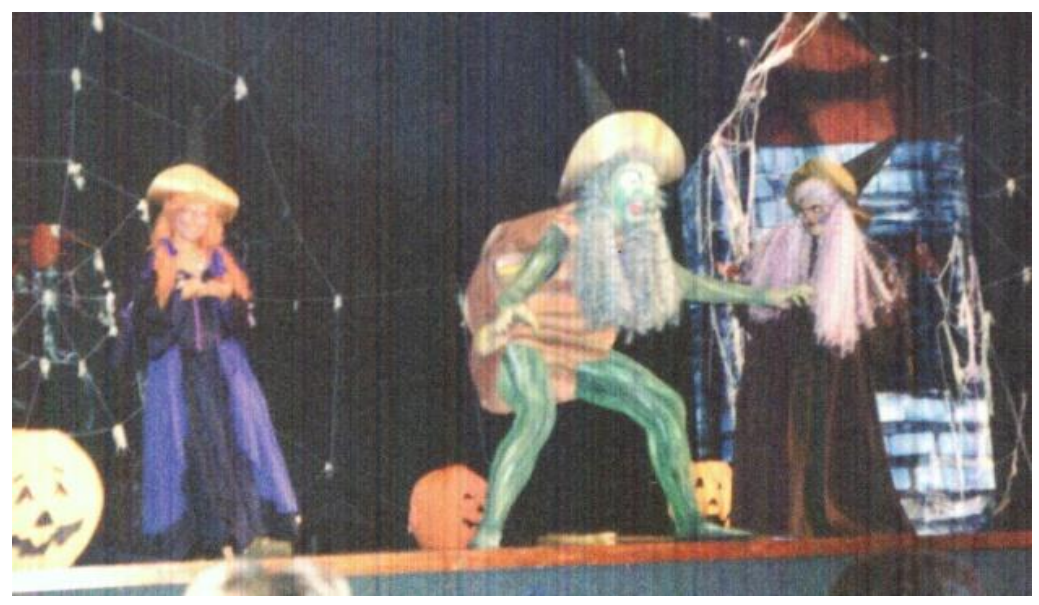

Figura 12 - Teatro Cia Camaleão - A bruxinha que era Boa, Maria Clara Machado - 1995-1996

Considero o corpo expressivo, como texto artístico e comunicativo visual. Ele tem seu propósito semântico ao seu eu-para-si, à sua consciência vivente e vivenciadora de sua vida (BAKHTIN, 2011, pag. 91). Foi assim, a partir da expressividade do corpo como texto, que participei ativamente do grupo e também da comunicação entre meus amigos do teatro e público.

Mas só ocorria no teatro a expressividade comunicativa. Fora dela, as aulas na escola e também em grupo ainda permanecia a identidade de deficiente auditiva. Não conseguia participar das conversas, pois cada conversa precisava ser individual; no coletivo me sentia sempre excluída, sempre a tentar compreender as falas.

Esses fatos ocorreram porque não tinha conhecimento da comunidade surda e da LIBRAS e também das crenças de que pessoa deficiente tinha capacidade limitada para algumas coisas. Como eu me via como deficiente auditiva, deixei de perceber muitas coisas boas na cultura surda. Era como se eu tivesse um rótulo, uma marca, uma categoria em que criei essa visão sobre mim, vivenciando na comunidade ouvinte em que retrata o corpo como um objeto ajustável, dócil, transformado e ajustado conforme as ideologias dominadas pelo padrão da sociedade atual:

Minha realidade na época, fora do teatro, era retratada conforme Lane quando descreve as experiências retratadas pelos surdos ao tentarem serem aceitos e também sobreviver à comunidade audistas ${ }^{28}$ :

\footnotetext{
${ }^{28}$ Termo referente às práticas da normalização e medicalização do surdo, muitas vezes rejeitam a cultura, identidade e língua de sinais. O livro " A máscara da benevolência: comunidade surda amordaçada" de Harlan Lane descreve bem sobre o termo. Este livro se encontra na referência bibliográfica.
} 
Quase todos os informantes descreveram a sua vida social em termos de solidão, rejeição e discriminação social. Para se inserir o melhor possível numa classe para ouvintes, a criança surda esconde seu aparelho auditivo, finge que compreende as lições, quando na realidade não compreende, copia os trabalhos dos outros alunos, raramente faz perguntas na sala de aula ou se voluntaria para responde-las, fala o menos possível com os estudantes ouvintes, ou até mesmo com os estudantes surdos. Uma criança tentando inserir -se na sociedade, escreve: detesto que as pessoas saibam que sou surda. (LANE, 1992, pag.128)

Era assim eu, queria tentar ser aceita pela comunidade ouvinte mesmo sabendo da minha deficiência.

\subsection{O despertar para a LIBRAS}

Por muito tempo, eu não conhecia outros surdos e sua comunidade linguística e cultural. De fato, em Dourados era raro encontrar surdos. Lembro-me de ter tido colegas surdos, apenas dois colegas, numa sala de aula de $3^{\mathrm{a}}$ série, em 1989. Apenas tinha nós três. A professora fazia atividades individuais e, claro, sempre focada na leitura labiais. Nós éramos deficientes auditivos e usávamos aparelhos auditivos. Existia um momento único nosso, começava a usar "sinais caseiros", algo que nós criávamos para nos comunicar. Lembro-me que com os sinais, a sensação de comunicação se tornava completa, assim como as categorias de Peirce:

Primeiridade reúne aquilo que é sem nenhuma relação de qualquer espécie com qualquer outra coisa. É autocontida, auto-refletiva e auto-suficiente. Secundidade é aquilo que é somente ao entrar em relação com alguma coisa, interagindo com ela no sentido de alguma coisa aqui e alguma coisa lá; a primeira coisa atua como um signo e a segunda coisa como o objeto do signo. Terceiridade é aquilo que é; reúne primeiridade e secundidade estabelecendo uma mediação entre elas e, portanto, se coloca em interação com elas da mesma maneira que elas são colocadas em interação uma com a outra (MERREL, 2003, pag.164)

Quando eu e os colegas surdos trocávamos entre nós os "sinais caseiros", ocorriam uma espécie completa de primeiridade, secundidade e terceiridade. Enquanto eu lia os lábios das pessoas ocorria em mim apenas primeiridade e secundidade. Porque essas diferenças? Com os sinais, as percepções da fala se tornavam completas a compreensão, enquanto nas leituras labiais, as falas se tornavam fragmentadas, incompletas, sempre faltando algo a completar a frase. Esses atos retratam bem as categorias de Peirce, conforme mostra a figura de como seriam a fala visual e a fala oral para uma pessoa surda: 


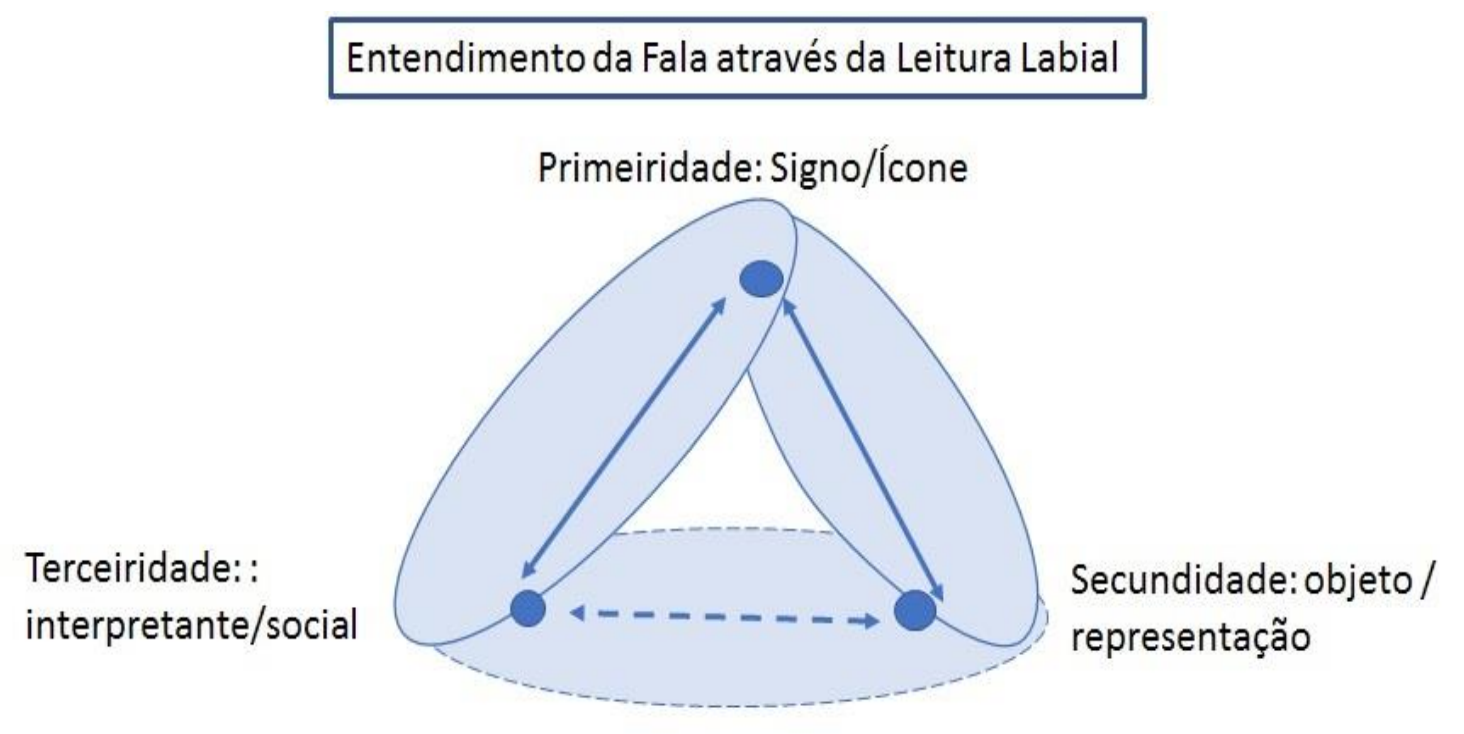

Figura 13 - Fala como Leitura Labial

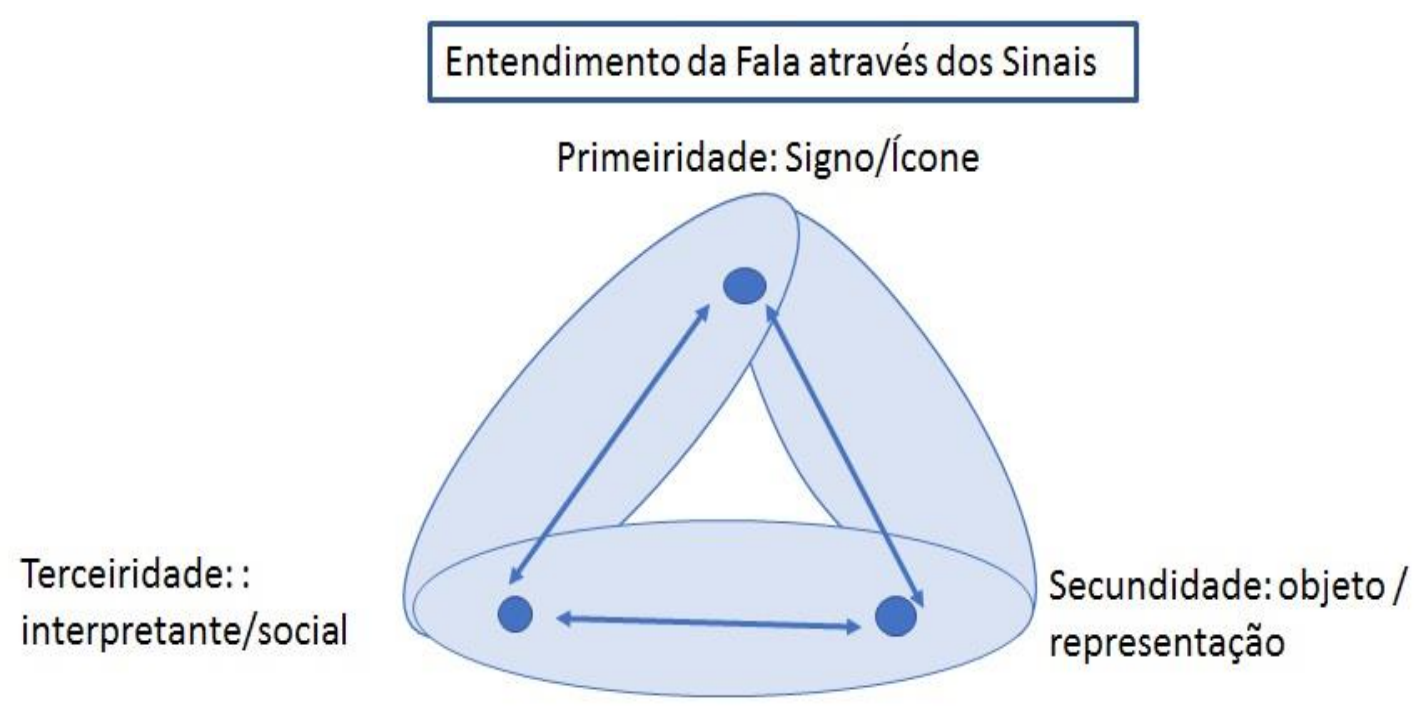

Figura 14 - Fala como Sinal

Ao observar a figura 13, o círculo está tracejado porque ocorre uma demora na assimilação da mensagem, pois são tentativas de enquadrar qual é a linguagem que está 
representando, tendo em vista que a leitura labial sempre possui conflitos de identificação da fala oral, na visualidade, assim como diz a professora Cida: "Era todo silábico e com som muito parecido ela confundia na hora da pronuncia nos ditados, como por exemplo, $M$ com $B, T$ com $D$ e assim por diante". Já na figura 14, quando começa a compreender a fala por sinal, se torna a categoria completa, a sinalidade é mais perceptível, mais clara de relacionar e assimilar, pois os olhos desempenham uma dupla função de linguagem.

Minha descoberta da LIBRAS ocorreu em 2005, aos 25 anos de idade. Nunca em minha vida eu tinha conhecimento ou comentários a respeito da LIBRAS. Minha visão sobre a LIBRAS é que ela me permitiu abrir os horizontes sobre a comunicação, apesar da dominação da leitura labial.

Demorou muito tempo para que eu conhecesse a LIBRAS. A Lei da LIBRAS, a Lei ${ }^{\circ}$ 10436/2002, preconiza que o surdo tem o direito de se expressar e ter o reconhecimento da LIBRAS (Língua Brasileira de Sinas) como sua língua. Os surdos já são constituídos como comunidade, portanto possuem agora cultura e língua diferentes da comunidade ouvinte. Somente em 2005 é que pude ver os surdos visíveis da comunidade; num dia em que estava voltando para minha casa, aguardando o ônibus na estação de transbordo, vi três surdos “moverem” suas mãos e braços no ar, numa beleza de movimentos rítmicos, sintonizados com as ondas de radiofônicas, mas de uma forma de linhas sinuosas, circulares, verticais e horizontais. Aquela visão me dava a sensação de ouvir um som, uma música ritmada, mas todos baseados na visualidade e sinalidade. De longe, percebia algo familiar recordando a minha época dos meus dois amigos surdos da $3^{\text {a }}$ série. Não conseguia compreender, pois estava muito diferente, mais sinais. Aquele momento deu-me uma sensação familiar, a sensação da linguagem sendo fluida na consciência imediata, aquilo que estava oculto nas linguagens torna-se perceptível agora numa consciência de Terceiridade.

$\mathrm{E}$ as mãos davam formas que lembravam signos de coisas, fatos, conceitos, símbolos. Meu conhecimento de mundo era bastante limitado, utilizava a leitura labial e a escrita como únicos meios de comunicação, mas de uma forma bastante fragmentada. Sentia-me incompleta quando da ausência da LIBRAS. Naquele momento, fui "percebida" pelos surdos por causa do meu aparelho auditivo e me perguntaram em sinal "VOCÊ SURDA?". Recebi um susto pois não conhecia o sinal, não sabia dar resposta, apenas levantei meus ombros e mãos para cima, em "gesto" de que "eu não sei o que falam". Logo em seguida me deram um “Tchau" ou "adeus"? Aquela despedida me fez quase chorar, quase a perder alguém. Foi um momento em que me senti tão querida e importante. 
Aquele dia, não saiu mais da minha cabeça como recordação. Um dia, um professor da Educação Especial da Secretaria Municipal de Educação foi ministrar um curso normal de formação continuada. Qual foi minha surpresa, ele me perguntou se eu sabia LIBRAS. Disse que não conhecia e nem sabia o significado de LIBRAS. Por curiosidade ele me perguntou se eu conhecia o significado de uma palavra, não me recordo qual. Qual foi minha surpresa que eu sabia o significado da palavra e que um outro surdo não sabia. Isso me despertou uma curiosidade, porque eu tinha conhecimento da escrita e da palavra e um outro surdo não tinha esses conhecimentos. A partir daí ele me convidou para eu fazer um curso de LIBRAS e que prontamente aceitei, pois estava curiosa em saber como é, e também minhas leituras labiais começavam a me dar mais cansaço, minha surdez aumentou consideravelmente e a visualidade tornou-se mais aguçada.

Esta noção da falta de conhecimento e contato com a comunidade surda e língua de sinais é o mesmo que ocorreu no processo que iniciou as tentativas de apagamento da língua de sinais e cultura surda pelo Congresso de Milão, além da filosofia do Positivismo, do Método Cartesiano pela busca pela perfeição, pelo corpo dócil e manipulado, o "biopoder" que Foucault retrata. Isso ocorre em muitos casos de surdos vindos de família ouvintes que buscam a "cura" para seus filhos voltarem a ouvir. Há outros casos também da falta de conhecimento a respeito da cultura e identidade que é a falta de acesso a essas informações. Em outros casos, médicos já orientam famílias a evitarem a língua de sinais, justificando que esta poderia trazer prejuízo às linguagens e desenvolvimento da língua oral.

Por tanto tempo não pude ter acesso à LIBRAS, por tanto tempo minha vida teve um vazio jamais preenchido, por tanto tempo o vazio da Terceiridade era sentido, do texto incompleto, faltando sempre a sinalidade.

Ao adquirir a LIBRAS, a visão da comunicação passou a se tornar para mim mais clara e completa. Posso explanar através do Conceito de Texto Visual retratado por Lótman e mais adiante por Peirce.

Texto é algo difícil de se definir, ele pode ser representado por signos arbitrários que se tornam organizadores de ideais pré-conceptas do pensamento. O Eu de cada um de nós tem uma maneira que só o "eu organizo meu interior - que vive, tem vontade, ama, sente, vê e conhece - de dentro, em categorias de valores totalmente diferentes e que não se aplicam de modo imediato à minha expressividade externa" (BAKHTIN, 2015, pag.28).

O conceito de texto para Lótman engloba o signo e seus sistemas de signos ligados ao problema da significação. Quando tinha a ausência da sinalidade e utilizava apenas a oralidade, muitos signos não tinha uma significação para mim ou precisavam de uma nova 
significação para melhor ser assimilado, pois a atividade semiótica, que é a transmissão de um determinado conteúdo, produz as sensações de não assimilar o signo como significado, isto é, dentro de um texto auditivo (oral) (LÓTMAN, 1978, pag.74).

A LIBRAS como língua de modalidade visual é representada através dos cinco parâmetros $^{29}$ que são seus movimentos, expressão facial, configurações de mãos, classificadores, orientação e direcionalidade, tornando-se um todo, um signo arbitrário que, por sua vez, através de seu conjunto de sistema de signos, tornam-se um texto visual que sempre cumpre a função de geração de sentidos.

Como havia situado na figura 11 e 12, quando da ausência fragmentada provocada pela falta da sinalidade, ela se torna um esquecimento da significação pelo fato de que a comunicação constitui a essência da abordagem semiótica.

Meu corpo pôde sentir essa experiência fenomênica quando da diminuição da audição e aumento da capacidade visual. Os olhos passam a ter a dupla função da linguagem da assimilação dos signos em significação. Para um melhor entendimento sobre o esquecimento, Lótman (1978, pag. 74) afirma que:

O esquecimento da significação não pode ser o resultado de um método que coloca ao centro a investigação do próprio problema da semiose. É precisamente o estudo do que significa "ter uma significação", do que é o acto de comunicação e qual é o seu papel social que constituiu a essência da abordagem semiótica. No entanto, para compreender o conteúdo da arte, seu papel social, a sua relação com os aspectos não artísticos da atividade humana, não basta ter boa vontade, não basta também repetir indefinidamente verdades conhecidas de todos e demasiado gerais.

A LIBRAS passou a ser minha língua, minha essência da comunicação completa após muitos anos de sentidos vazios, ausentes, negritude do silêncio vivenciados ao longo de minha vida. Então a vida passou agora a ter um papel, a "ter uma significação" das coisas e fatos.

\footnotetext{
${ }^{29}$ Parâmetros da Libras são categorias fonéticas como se constitui um sinal.
} 


\section{CONSIDERAÇÕES FINAIS}

Na sociedade atual, tenho observado muito a pressão sobre a criança e o adulto surdo sobre o "dever" de saber e ler a língua portuguesa escrita. Ninguém até o momento se preocupou em respeitar a primeira língua da criança surda, neste caso a LIBRAS. O que tenho observado é que ainda há uma discriminação da sociedade sobre a LIBRAS. Principalmente nas famílias onde a criança surda é filha de pais ouvintes. A família faz uma "grande luta" para que a criança surda aprenda a "falar oralmente", "ouvir bem", submetendo-a implantes cocleares ou simplesmente aparelhos auditivos, a fim de dar "um pouco" de alegria aos pais ouvintes. Tenho observado muito isso através de minha vivência nas visitas às escolas que realizava há muito tempo e também hoje. Ainda existe a repreensão sobre a LIBRAS. Ou seja, ainda estamos vivendo o fantasma do Congresso de Milão.

Esta pesquisa de abordagem descritiva fenomenológica permitiu-me compreender que não estive sozinha nas discriminações, nos sofrimentos relatados por todas as experiências surdas. Minha análise nos dados sobre a escrita permitiu uma compreensão de que a escrita simboliza o ícone e a palavra, neste caso, a fala, o signo. A escrita representa o ícone de Peirce, a imagem pictórica representativa. A palavra representa o sistema de Saussure, ou seja, o sistema da língua. Escrita e palavra ambos são linguagens. Essas linguagens estão dentro de nós como sentimento, vontade e conhecimento. Esse entendimento deixou claro que mesmo que independente da língua que usamos, seja ela oral ou visual, ambas têm um processo de aquisição de acordo com o passar das experiências vivenciadas por todas as pessoas e não apenas surdos. E também essa pesquisa me permitiu uma análise bastante refletiva sobre a LIBRAS ou outras línguas de sinais que precisam ser adquiridas deste cedo pelas crianças nascidas surdas ou adquiridas a surdez depois. A LIBRAS me mostrou, através de minha experiência, de que eu necessitava muito da visualidade para poder entender e me comunicar. As apontações representavam a visualidade, as expressões faciais também representam a visualidade, enfim o corpo como Texto Visual.

Peirce e Lótman caminham juntos comigo para poder compreender a essência do fato da LIBRAS ter aberto meu olhar entre as comunicações e significados das essências dos coisas e fatos. Mesmo tendo adquirido tardiamente a LIBRAS, eu pude recuperar o tempo perdido indo a palestras, seminários, aulas todas em LIBRAS a partir de uma nova Faculdade que fiz, o Letras LIBRAS. A faculdade oportunizou para mim e outros amigos surdos uma nova oportunidade de ser reconhecidos como comunidade linguística e cultural. Foi desta 
forma que eu pude me orgulhar e assumir a Identidade Surda. Mesmo tendo eu passado pela identidade de deficiente consegui quebrar o "rótulo".

Foucault e Benveniste foram os filósofos que me permitiram compreender e analisar a discriminação sofrida pelas pessoas surdas e sua língua. Marques permitiu ver meu corpo, analisar meu corpo no passado, depois de mais de 30 anos em que adquiri a escrita, e através dele pude também entender meu corpo através do filósofo Merleau-Ponty.

Transcrevo uma citação de Foucault, sobre a essência deste trabalho em que me levei a dar conta sobre a escrita e a fala (palavra) que são conceitos essencialmente diferentes, podendo ser adquiridos sim pelas pessoas surdas, mas de uma maneira única e particular, pois deverão respeitar sempre em primeiro lugar a língua da criança surda que é a LIBRAS. Num ambiente que privilegia em absoluto a escrita, o que vocês pensam sobre a língua do surdo? Reconhece que o surdo possui uma língua própria? Até quando vão os ouvintes admitir que o surdo seja obrigado a adquirir a escrita baseado nos princípios da Língua Portuguesa Oral? Quando vão reconhecer a LIBRAS como primeira língua do surdo?

\footnotetext{
Doravante, a linguagem tem por natureza primeira ser escrita. Os sons da voz formam apenas sua tradução transitória e precária. O que Deus depositou no mundo são palavras escritas; quando Adão pôs os primeiros nomes aos animais, não fez mais que ler essas marcas visíveis e silenciosas; a Lei foi confiada a Tábuas, e não à memória dos homens; e a verdadeira Palavra, é um livro que devemos encontrar. Tanto Virgenére como Duret diziam - termos quase idênticos - que a escrita precedera sempre a fala, certamente na natureza, talvez mesmo no saber dos homens. Pois poderia bem ser que antes de Babel, antes do Dilúvio, houvesse uma escrita composta pelas mesmas marcas da natureza, de tal sorte que esses caracteres tivessem o poder de agir diretamente sobre as coisas, atraí-las ou repeli-las, figurar suas propriedades, suas virtudes e seus segredos (FOUCAULT, 2000, pag.52).
}

A língua então se completa com a LIBRAS. Ela se tornou a essência da minha comunicação na sociedade entre as fronteiras do mundo ouvinte e surdo. A LIBRAS é minha essência de Língua. 


\section{REFERENCIAS}

BENVENISTE, É. Problemas de linguísticas geral I, tradução de Maria da Glória Novak e Maria Luisamneri, $4^{a}$ edição - Campinas: Pontes, 1995.

Campinas-SPAG. Pontes, 1989.

Problemas de linguísticas geral II. Tradução Eduardo Guimarães.

CARVAlHO, P. V. Breve História dos surdos no Mundo. Lisboa: Surd'Universo, 2007.

O Abade de L'Epée no Século XXI. Lisboa: 2012.1 ${ }^{\text {as }}$ Jornadas da LGPAG. Língua. Ensino. Interpretação. ESEC - Escola Superior de Educação de Coimbra. Acesso em 15 de agosto de 2016, disponível em $<$ http://www.porsinal.pt/index.php?ps=artigos\&idt=artc\&cat=7\&idart=307>.

BAKHTIN, Mikhail. Estética da criação verbal. $6^{\text {a }}$ edição. São Paulo: Editora WMF Martins Fontes, 2011.

DAVALLON. Jean. A imagem, uma arte de memória? In: ACHARD, P; DAVALLON, J; DURAND, J-L; PÊCHEUX, M; ORLANDI, E. PAG. Papel da memória. $4^{\text {a }}$ edição. Campinas-SP: Pontes Editores, 2015.

DESLOGES, PAG. Observations D'um Sourd et muèt sur um cours élémentare. D'éducation des sourds et muéts. 1779. Disponível em < http://gallica.bnf.fr/ark:/12148/bpt6k749465/f5.item.r=34.shift.zoom>.

DESLOGES, Pierre. Observações de um surdo-mudo sobre um curso elementar de educação de surdos-mudos, publicado em 1779 pelo Abade Deschamps, Capelão da Igreja de Orléans. Tradução de Daniela Valle de Loro (não publicada). Paris: B. Morin, 1779.

FERREIRA, L. Por uma gramática de Língua de Sinais. Editora tempo Brasileiro, 2010.

FOUCAUlT, M. Vigiar e Punir. (R. Ramalhete, Trad.) 20ª ed. Petrópolis: Vozes, 1989.

. As palavras e as coisas: uma arqueologia das ciências humanas. Tradução

Salma Tannus Muchail. - $8^{\mathrm{a}}$ Ed. - São Paulo: Martins Fontes, 1999. - (Coleção tópicos). Acessado em 08/10/2015: http:<//tv.upag.pt/uploads/attachment/file/318/foucault-michel-aspalavras-e-as-coisas-digitalizado.pdf $>$.

. In: Las Meninas e A prosa do Mundo. As palavras e as coisas: uma arqueologia das ciências humanas. São Paulo: Martins Fontes. 2000. p. 03-61.

LABORIT, E. O vôo da Gaivota. São Paulo: Best Seller, 1994

LADD, PAG. Em busca da Surdidade 1 - Colonização dos Surdos. (M. M. Sintagma, Trad.) Lisboa, PT: Surd'Universo, 2013. 
LANE, H. A máscara da benevolência: a comunidade surda amordaçada. Instituto Piaget. Horizontes Pedagógicos. Lisboa, 1992

LÓTMAN, Iuri. Teoria: A estrutura do texto artístico. Trads. M.C.V. Raposo \& A. Raposo. Estampa. Lisboa, 1978. pag. 101 a 112.

MACHADO, Irene. Escola de Semiótica: A experiência de Tártu-Moscou para o Estudo da Cultura. Ateliê Editora FAPESP, 2003.

2. Agosto de 2013.

. Pensamento semiótico sobre a cultura. SOPHIA. Vitória (ES), vol 02, n

MARCUSCHI, L.A. Da fala para a escrita: atividades de retextualização. São Paulo: Cortez, 2004.

MARQUES, R. R. A percepção do corpo próprio e o "ser surdo" (Vol. n. 9).Florianólopis: Ponto de Vista, 2007.

A experiência de ser surdo: uma descrição fenomenológica. Tese de Doutorado em Educação. Florianópolis, agosto de 2008. Disponível em: $\langle$ https://repositorio.ufsc.br/handle/123456789/91744>.

MARTELOTTA, Mario Eduardo (org.). Manual de Linguística. São Paulo: Contexto, 2008. MERRELL, Floyd. Iúri Lótman, C. C. Peirce e semiose cultural. Revista Galáxia, nº 05. Abril de 2003. pag. 163-185.

PIZZIO, A. L CAMPELLO, A. R.S., REZENDE, PAG. L. F., QUADROS, R. M. Língua Brasileira de Sinais III. Apostila do Curso de Letras LIBRAS. Florianópolis. 2009. Disponível em: $<$ http://www.LIBRAS.ufsc.br/colecaoLetrasLIBRAS/eixoFormacaoEspecifica/linguaBrasileir aDeSinaisIII/assets/263/TEXTO_BASE___DEFINITIVO___2010.pdf >.

PIZZIO, A. L., REZENDE, PAG. L. F., QUADROS, R. M. Língua Brasileira de Sinais V. Apostila do Curso de Letras LIBRAS. Florianópolis. 2009. Disponível em: http:,//www.LIBRAS.ufsc.br/colecaoLetrasLIBRAS/eixoFormacaoEspecifica/linguaBrasileir aDeSinaisV/assets/576/TEXTO_BASE_-_LIBRAS_V.pdf $>$.

QUADROS, R. M., KARNOPP, L. B. Língua de Sinais Brasileira: estudos linguísticos. Artmed Editora, 2004.

STROBEL, K. História da Educação de Surdos. Texto base. Florianópolis: UFSC,2009.

SACKS, O. Vendo Vozes - Uma viagem ao mundo dos surdos. (L. T. Motta, Trad.) São Paulo: Companhia das Letras, 2010.

SANTAELLA, Lúcia. O que é Semiótica. Coleção 103. Editora Brasiliense. Livro digitalizado e formatado para Projeto Democratização da Leitura. Htttp/ www.portaldetonando.com.br

SAUSSURE, F. Curso de Linguística Geral. 28ª ed.. São Paulo: Cultrix, 2012. 
SKLIAR, C. A surdez: um olhar sobre as diferenças. 3ª ed. Porto Alegre: Mediação, 2005.

STROBEL, K. L. História da Educação de Surdos. Florianópolis: Universidade Federal de Santa Catarina - Curso Letras/ LIBRAS - Educação a Distância. 2009. Acesso em 15 de agosto de 2016, disponível em: <http://www.LIBRAS.ufsc.br/colecaoLetrasLIBRAS/eixoFormacaoEspecifica/historiaDaEdu cacaoDeSurdos/assets/258/TextoBase_HistoriaEducacaoSurdos.pdf $>$.

VILHAVA, Shirley. O despertar do silêncio. Editora Arara Azul. Petrópolis. Rio de Janeiro. 2004. Disponível em: 〈http://editora-arara-azul.com.br/site/ebook/detalhes/10>. 


\section{ANEXOS -CORPUS}

Texto 1: corpus Maria de Fátima, mãe:

Outubro de 2015

Ana Paula, quando tinha 3 anos, menina inteligente, cativa, sempre chamando a atenção de todas as pessoas por onde passava. Uns dias antes de ficar doente, fomos a um show na praça Ari Coelho e para que ela pudesse ver melhor, o papai colocou-a no palco. Enquanto os artistas sairam para se arrumar deixaram uma música e ela de repente começou a dançar no palco como se fosse uma das personagens. E as pessoas gritavam e batiam palma, vibravam muito. Sempre foi desinibida.

Não me recordo o mês se era setembro. Domingo de manhã fomos visitar uma prima de quem a gente tem muito carinho e brincando com as outras crianças ela bateu a nuca em uma quina de uma cadeira. A partir desse momento ela começou a ficar diferente. Quieta e pálida. Á noite começou febre muito alta. Levamos no Hospital Militar e lá fizeram compressa com toalha molhada pois não abaixava a febre com antitérmico. E assim foi a madrugada toda.

Voltamos para casa, mas tivemos que voltar de manhã. Eu me lembro que eu não conseguia segurar o pescoço dela. E assim veio um médico olhava, outro e não entendiam o que estava acontecendo, foi indo que até as 12:30 mais ou menos ela teve uma parada cardíaca e foi reanimada. A partir desse momento, quando ela voltou ela estava falando diferente. A primeira coisa que pediu: "Fanta! Hum! Que cheiro de fanta". Um soldado saiu em busca dessa fanta e trouxe para ela (é interessante que ela gostava de coca). E começou a dizer para os médicos e enfermeiros: "eu fui embora e voltei agora bem nenezinha desse tamanho!"

E assim foi a tarde toda conversando e quando chegou à noite, ela batia muito a perninha que estava machucada pela bicicleta uns 15 dias antes. Era onde estava o soro e a perna dela começou a ficar com anorexia (azulado), isso foi até de manhã, quando precisei ir para casa ver o outro bebê que eu tinha de 8 meses, mas fui triste pois achava que minha filha estava morrendo e eu não queria ver mais aquele sofrimento. Um ano antes, eu já tinha passado pelo sofrimento da perda do meu segundo filho Lucas. 
Chegando em minha casa, uma amiga que era espírita fez uma oração pedindo a Deus que ela se libertasse daquele sofrimento e mandaram passar salmoura na perna dela e foi o que fiz indo ao hospital.

Quando cheguei estava o maior tumulto pois ela tinha tido outra Parada Cardiorrespiratória e o meu marido estava desesperado pelo que estava acontecendo. Mas já havia solucionado o caso.

Passamos a salmoura, em poucos minutos foi voltando ao normal a perna dela. Vieram a partir desse momento muitos médicos de outros hospitais. Fizeram a Punção e viram que o Licor era cor-de-rosa e por isso a suspeita era que estava com Meningite bacteriana e tudo isso aconteceu porque fazia um mês que ela havia machucado o pé no aro da bicicleta e ainda não havia sarado mesmo com todos os cuidados tomados.

Assim ela ficou isolada no Hospital Militar por 30 dias. Quando ela saiu e veio para casa foi voltando aos poucos tudo ao normal, ela brincando.

Quando chegou o domingo o pai dela ficou de plantão e ligou para ela eu a chamei ela atendeu mas disse para mim: "Meu pai não está falando”. Então pensei que ele estava em algum lugar. Qual não foi a minha surpresa quando percebi que ele estava falando com ela. Foi o maior sofrimento para mim a partir deste dia. Uma amiga veio nos visitar a tarde e nos disse assim: "ainda bem que ela não ficou surda". Neste momento de sofrimento, começou também o nosso "Crescimento”. Para que ela tivesse sempre o melhor, procuramos todos os "Recursos Necessários".

Ficou um tempo ouvindo uns 50\%, depois perdia novamente a audição. Os médicos optaram por não pôr aparelho de audição.

Ela ficava uma época sem ouvir nada, depois voltava a ouvir e depois aprendia tudo o que não tinha aprendido. Era muito interessante e assim foi até chegar aos 6 anos, entrou no Pré-escolar. Ela reclama da professora até hoje, eu não sei porque, ela era muito boa, talvez não tinha compreendido o seu emocional pois ela necessitava de muita amizade e atenção e ela tinha muito pouco. Esse foi um dos motivos que eu mais mexi com as pessoas.

Ana Paula aprendeu sozinha a ler os lábios das pessoas. A partir do $1^{o}$ momento que ela parou de ouvir ela começou a ler os lábios das pessoas, nem mesmo nós pais percebemos. Quando fez os $1^{\circ}$ testes (profissional) percebemos que ela lia os lábios e começou a pôr um objeto na frente da boca para ela não perceber e não ler os lábios. Até hoje ela é assim: lê perfeitamente os lábios das pessoas, sente dificuldade se o homem tem bigode, se a pessoa não articular direito, quando criança fala muito rápido. 
Não gosto de ver uma criança no canto sozinha. Jamais eu permito, porque se estamos neste mundo e for para viver sozinha, o que nós profissionais da educação estamos fazendo? Então é algo para se pensar muito, o que estamos fazendo com uma criança. E isso acontecia na pré-escola os colegas não gostava de brincar por ela não ouvir e isso eu digo que faz parte da filosofia da escola, porque só no papel é muito bom, lermos tudo bonito, mas na hora que nós temos uma criança desse nível, que é a hora de aplicar a filosofia da escola, não se vê nada e as pessoas vão empurrando um para o outro. E não acontece nada o que precisa ser feito.

Aos 7 anos, entrou no $1^{o}$ ano (antiga $1^{a}$ série do $1^{\circ}$ Grau) a professora Cida Nabuco (minha deusa!). Tudo o que ela é hoje eu devo a ela. Eu sei que nós pais sempre fomos presentes, mas esse anjo veio para nos auxiliares. Na época a professora tinha muito medo por causa do método que era "A pata nada", cartilha formada para o próprio aluno, baseada na cartilha "Sodré".

Foi muito bom pois só escrevia com letra de mão no caderno de caligrafia. Cada palavra ela precisava desenhar e compreender. Depois tinha as frases. Tudo precisava desenhar. Aprendia todas as sílabas com "A" depois vinha com "E” e a criança já sabia ler. Tudo a professora entrava em contato conosco. Eu me lembro que ela começou o "AR" e ela não conseguia entender e foi a partir da palavra "mar" ela desenhou e foi embora. Em junho, ela lia tudo. Nunca vi tanta rapidez para ler e compreender um texto. Tanto que ela foi a melhor de nossos filhos na alfabetização, pois esse método ajudou a compreender textos e aprender a escrever textos. Sempre foi a melhor e eu acredito que deve ter sido por causa do método. Os professores nem imaginam a grandiosidade deste método, pois eles aprendiam a formar palavras e formavam uma cartilha para ler todos os dias. Eles aprendiam a "construir", que é a coisa mais importante é você "construir", a pessoa se sente valorizada, ela se sente que faz parte da construção do mundo.

Em 1987, viemos para Dourados, ela já com 8 anos estava na $2^{a}$ série e colocamos ela na escola particular para melhor ser atendida. Ela estava lendo muito bem e sendo bem caprichosa. Numa das tarefas de matemática que sempre tirou nota boa, ela entendeu o conteúdo que era o valor do quadrado, porém num dia de muita poeira e vento, acabou por sujar o caderno e a professora em vez de olhar o trabalho que foi feito, mandou um bilhete dizendo que precisava lavar as mãos antes de fazer a tarefa e escreveu bem grande com tinta vermelha. Quando chegou em casa eu perguntei: "Filha a professora gostou da tarefa? " Ela disse: "eu não sei, ela não disse nada, mas escreveu isso para mostrar para a senhora". E isso tudo por incrível que pareça eu estava pagando uma mensalidade "alta" para ser 
chamada a "atenção" e ser tachada para a professora de ser uma relaxada é isso que ela quis dizer.

Eu nesta época achava que pagar uma escola particular era o certo que eles iriam investir na minha filha. Puro Engano!!

Meu pai morreu em abril, minha filha era muito agarrada a ele, sofrendo muito trouxe o santinho (foto dele) para mostrar para a professora, ela simplesmente "durona" mandou guardar e não disse nada para ela.

Alguns dias se passaram fui a escola e subi as escadas sem avisar ninguém. Qual não foi a minha surpresa a professora estava esfregando um caderno no rosto de um menino que estava chorando. Eu quase sai do meu normal na hora. Ela ficou chateada comigo e perguntei sobre a Ana Paula. Ela disse que ela é inteligente, mas que não passaria de ano porque não conseguia fazer ditado. Eu disse para ela e se ela não tivesse mãos o que você faria? Quem disse que é um ditado que vai diagnosticar com que a criança saiba ou não. E muito brava disse para ela: A partir de amanhã, Ana Paula não vem mais nesta escola. Peguei a mochila dela e a levei embora. No outro dia ela estava em uma Escola nova particular pequena chefiada por uma grande "educadora" psicóloga Iracy. Devo muito a ela.

Terminou o $2^{\circ}$ e $3^{\circ}$ ano nesta escola. Ana Paula aprendeu a fazer ditado pois ela consegue ler bem os lábios. Mais uma vez achamos que ela precisava conviver com crianças então colocamos numa escola particular maior. O que aconteceu foi o seguinte: eu cheguei na hora do recreio para ver realmente como ela estava sendo inserida com outras crianças. Ela estava sozinha enquanto as outras crianças brincavam. Eu ficava com ela um pouco ela dizia que ninguém queria brincar, conclusão. No outro dia pedi transferência e a levei para uma escola do Estado onde eu também dava aula. Foi a melhor opção que ei já fiz. Quando chegou na escola, as crianças não sabiam o que fazer com ela de tanta alegria e nesta escola ela aprendeu a brincar, brincadeiras diferentes brincar de roda todos os dias. Os professores compreendera como ensinar a ela e aos outros alunos. Todos saíram, ganhando, pois, os educadores tiveram que aprender a falar olhando para os alunos por causa dela. Articulando bem as palavras para que ela lesse os lábios. Assim ela terminou o $8^{\circ}$ ano, nesta escola Capilé, a partir do $2^{\circ}$ Grau foi feito na escola Presidente Vargas. Fato interessante aconteceu que havia um professor de língua portuguesa, por sinal excelente professor e que usava barba a muitos anos e a Ana Paula não conseguia ler os lábios por causa da barba. Foi onde o professor tomou a dura decisão de tirar a barba, nessa grande 
atitude, os outros professores que também usava fizeram o mesmo, e assim beneficiou não só a Ana Paula, mas todos os alunos, não só esse gesto, mas os professores aprenderam que não deveriam andar na sala, explicando conteúdo e sim ficar parados na frente dos alunos e articulando as palavras. O desempenho dos alunos foi muito significativo, para a surpresa os professores. Nessa época começou a fazer teatro, inclusive participou de várias peças: Fantasminha, A Bruxinha que era boa, com a professora Gicelma.

Nessa mesma época, ela começou a aplicar a filosofia da vida, aprendeu a escrever palavras mágicas, a fazer o caderno de elogio e aprendendo a ver as partes positivas dela e todas as pessoas ao seu redor. É por isso ela melhorava cada vez mais em todos os sentidos, pois sempre foi muito religiosa.

Passou em dois vestibulares UFMS Educação Artística e UNIGRAN Ed. Artística, onde nós pais preferimos ela fazer na UNIGRAN.

Foi para a faculdade tirando sempre melhor nota. Passou no concurso como professora do Ensino Fundamental e lecionou 4 anos como professora de arte. 4 anos depois é aprovada em um $2^{\circ}$ concurso de técnica administrativa na UEMS. É nesse tempo que ela conheceu a LIBRAS. A partir daí foi para a secretaria de Educação Especial do Município a convite da Elza Pedroso e atuou por 7 anos à frente da educação de surdos. Conciliava entre dois trabalhos da UEMS e da Prefeitura.

Em 2007 casa-se e desse casamento nasce a primogênita Ana Sophia. E durante esse mesmo tempo, faz a $2^{a}$ faculdade Letras-LIBRAS.

Texto 2: Corpus de professora da $1^{\mathrm{a}}$ série, Cida*

Perguntas sobre experiência de vida na $1^{a}$ série de 1987, Jardim-MS, aluna surda (Deficiência Auditiva)

1- Quando você iniciou sua carreia como professora?

R=COMECEI MINHA CARREIRA COM 17 ANOS, EM 1980.

2- Você já tinha experiência de receber aluno com surdez?

$R=$ NUNCA TINHA TRABALHADO COM ALUNOS COM SURDEZ.

3- Ao receber a aluna surda, em 1987, na $1^{a}$ série, como você se sentiu?

$R=$ NO INICIO, APREENSIVA, POIS NÃO TINHA NENHUM PREPARO PARA

ALFABETIZAR UMA ALUNA COM SURDEZ. MUITO MEDO DE NÃO CONSEGUIR 
ALFABETIZÁ-LA. TIVEMOS MUITAS DIFICULDADES SIM, NOS DITADOS, NAS INTERPRETAÇÕES, MAS VENCEMOS TODAS ESSAS DIFUCULDADES, FOMOS NOS ADAPTANDO, E SUPERADO TODAS AS DIFICULDADES.

4- Como foi sua experiência de ensino?

$R=A$ MELHOR EXPERIÊNCIA DA MINHA VIDA PROFISSIONAL.

5_ houve momentos de angústia, pesquisa, sucesso elou ajudas recebidas?

$R=S I M$, PORQUE EU ACHAVA QUE O MÉTODO NÃO ERA ADEQUADO PARA UMA ALUNA COM ESSE PROBLEMA.ERA TODO SILÁBICO E, COM SOM MUITO PARECIDO.ELA CONFUNDIA NA HORA DA PRONUNCIA, NOS DITADOS, COMO POR EXEMPLO, M COM B, T COM D E ASSIM POR DIANTE.

6- Ao ver as formas de ensino, você concordou consigo mesmo sobre o lecionar para uma criança surda?

$R=$ NÃO, QUESTIONEI MUITO MINHA COORDENADORA NA ÉPOCA, PORQUE ACHAVA O MÉTODO TOTALMENTE INADEQUADO PARA UM ALUNO COM SURDEZ.

7- Conte-nos como você se sente hoje, em relação ao que aconteceu no passado e o que você espera contribuir para outras pessoas?

$R=$ COMO JÁ DISSE, FOI MINHA MELHOR EXPERIÊNCIA NA VIDA PROFISSIONAL, O MÉTODO NÃO ERA O MAIS ADEQUADO, MAS A BUSCA DE ALTERNATIVAS, E O AMOR QUE NOS ENVOLVEU, FOI O MAIS IMPORTANTE PARA O SUCESSO DA ALFABETIZAÇÃO DA ANA PAULA.

A PRESENÇA DA FAMÍLIA, O AMOR E CARINHO DOS PAIS, TENHO CERTEZA, QUE FOI FUNDAMENTAL PARA ELA SER ESSA ADULTA MARAVILHOSA QUE É HOJE, PROVA DE SUPERAÇÃO. E SABER QUE EU TIVE, EM ALGUM MOMENTO, PARTICIPAÇÃO PARA ELA TER SE TORNADO ESSA PESSOA MARAVILHOSA QUE ELA É HOJE, VENCEDORA, É TER A CERTEZA QUE VALEU A PENA MEUS 25 ANOS DE PROFISSÃO NA SALA DE AULA.

HOJE ESTOU APOSENTADA, MAS SEMPRE QUE VEJO PESSOAS COM LIMITAÇÕES, PROCURO SEMPRE FALAR:"VOCÊ É DIFERENTE, TEM LIMITAÇÕES SIM, MAS NÃO É IMPOTENTE, VOCÊ É CAPAZ!!

Este texto foi solicitado pela mestranda por e-mail, à professora Cida, 2015. 
ANEXOS - REGISTROS DE ATIVIDADES E MEIO JORNALISTICO 


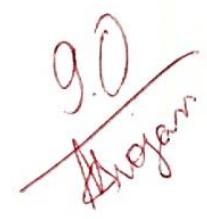

Exs. Est. Pré Excolar, 1". 2 "graus "Cel Felíio" yordion, 23 de funho de 1987.

Siluno $(a)$

Biflessona: Cutia 19 séris 33

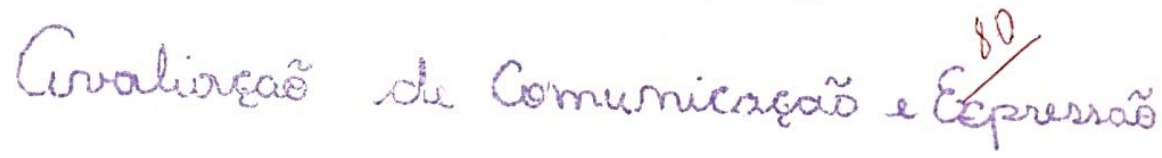

Marta e a macaca

Thater é a pricía

Marta ama la macaca. leanamada.

A macaca acha a lata de bananada A macaca acaba com a lata de

leanamada. a macaca e' safada.

Sria o texto e ilustro:
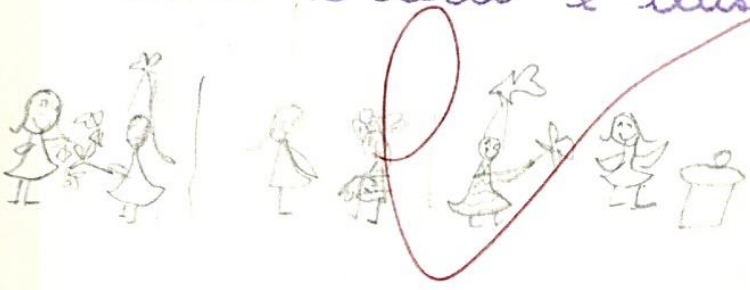
1) Laia o texto e complete:

Marta e'a fada

Marta uma a mácáca

Desenhe:

C fada Marta ganhs a:

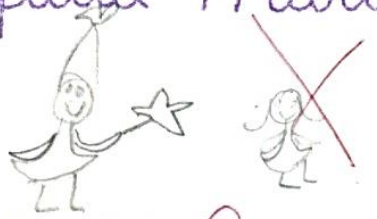

A macopa acaba com a lota de banamadof

Savia edesenhe:

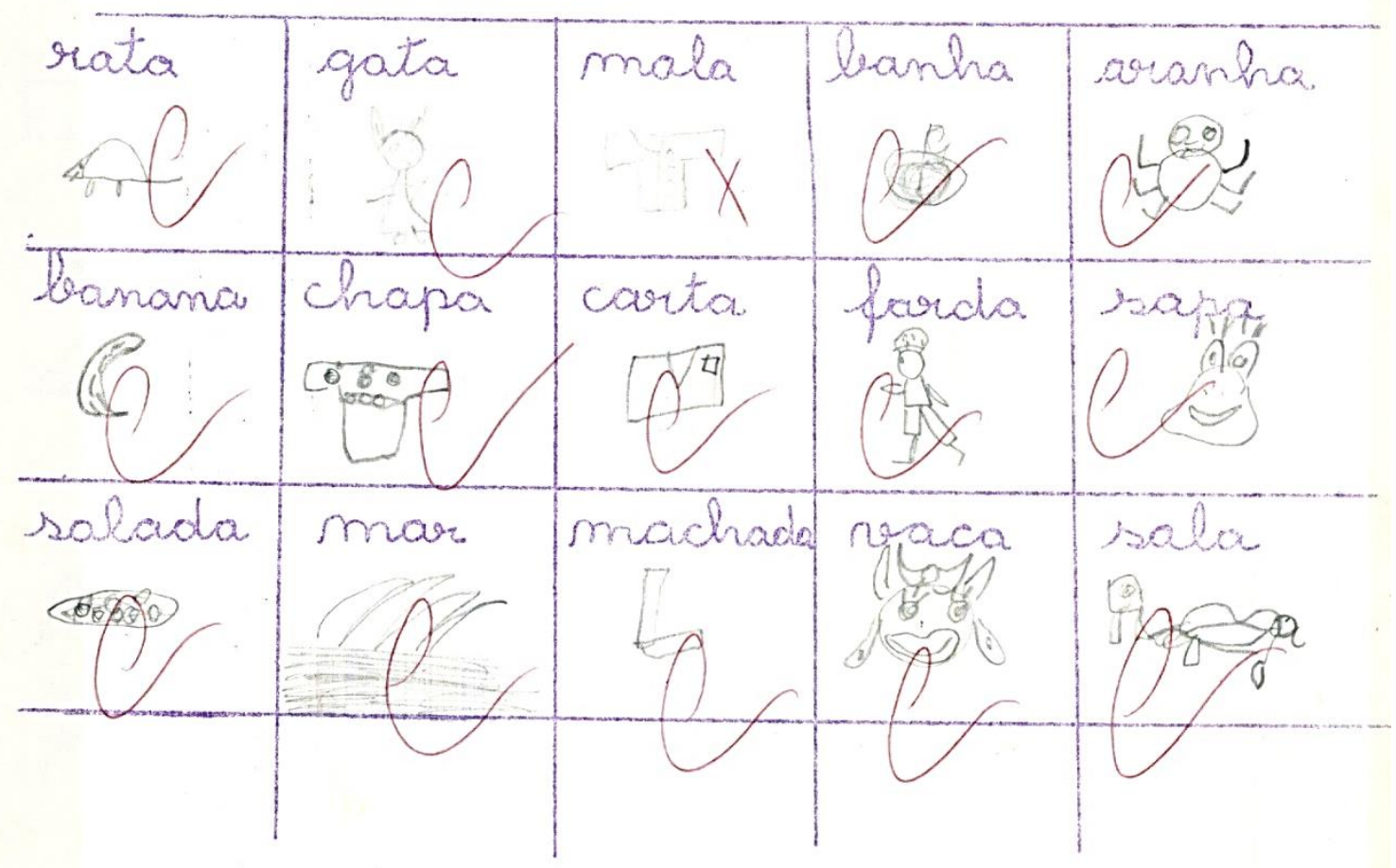




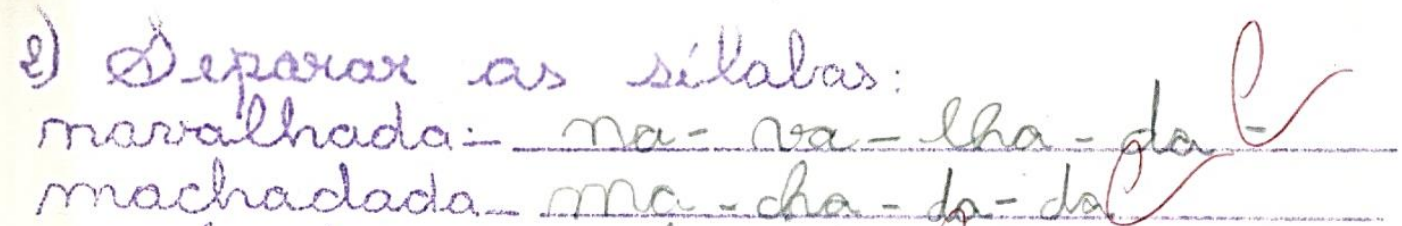
machadada ma cha-da-daly rowhada - radhog-da marchar-mar-crarginharea ga-mhou-

gata Agata é da rata. C acalar - salá acaloa gamha a macaca ganha

Emereva palaruas form:

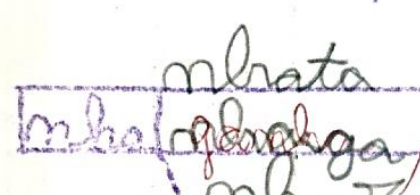
inhas.

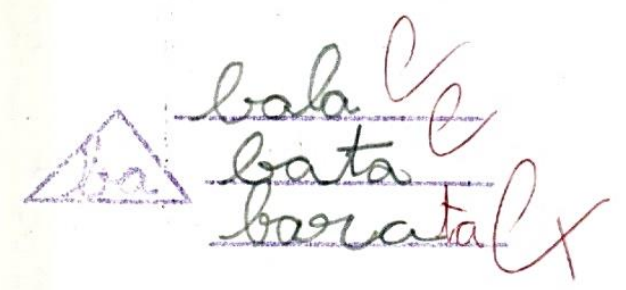

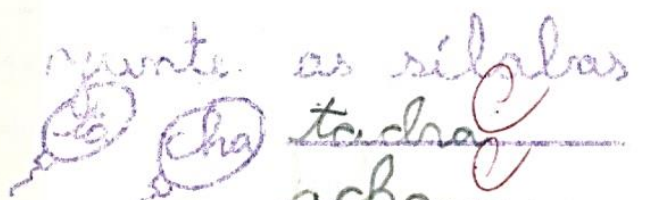
acha macha (a)

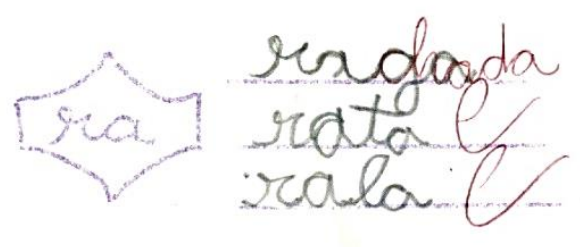
chanoda $y$

Mrgarda rala chaga,

- fermo palavias

ga) gara rosto gataf 


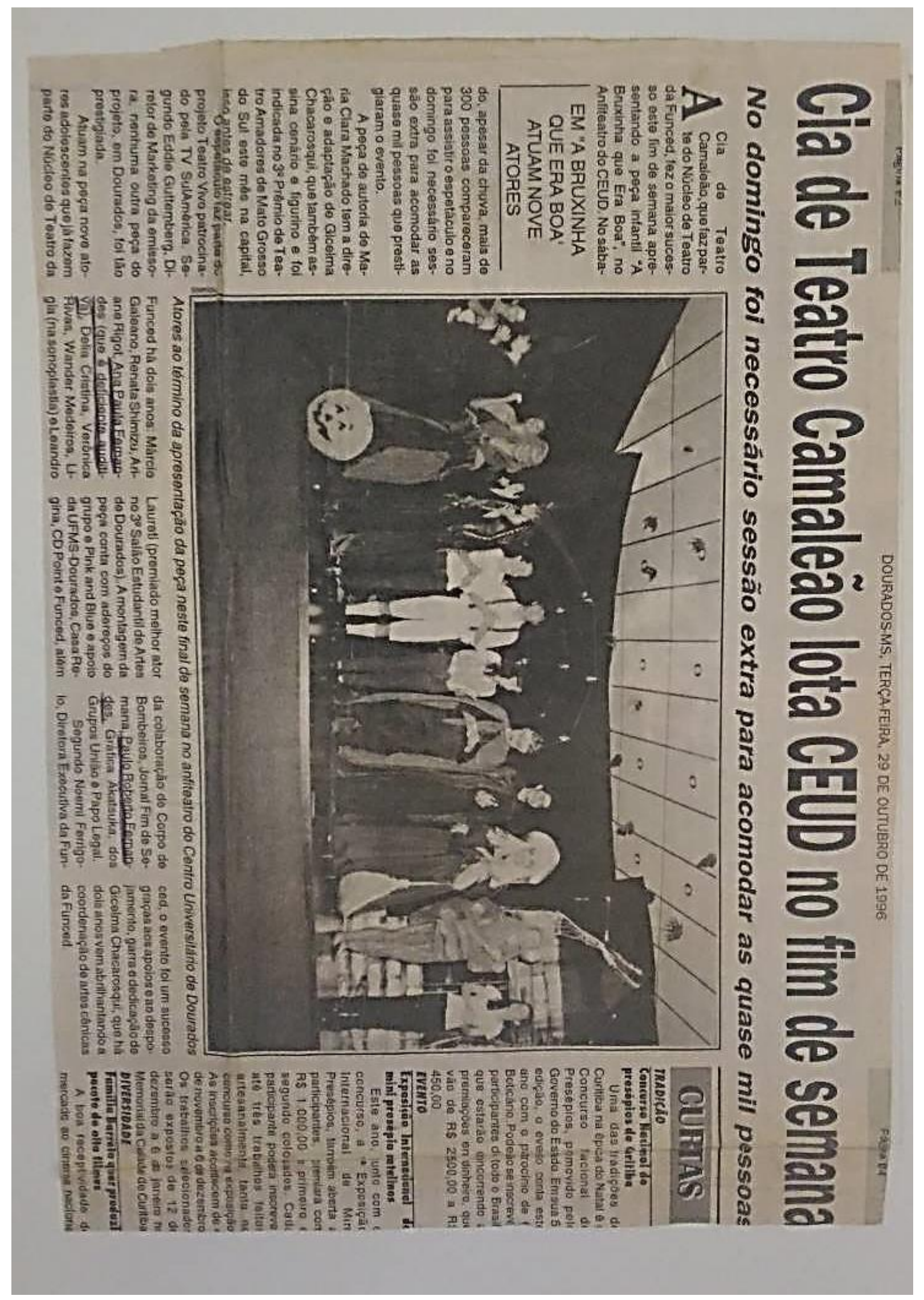


jomal Diário do Povo - 29 de outulro de 1986

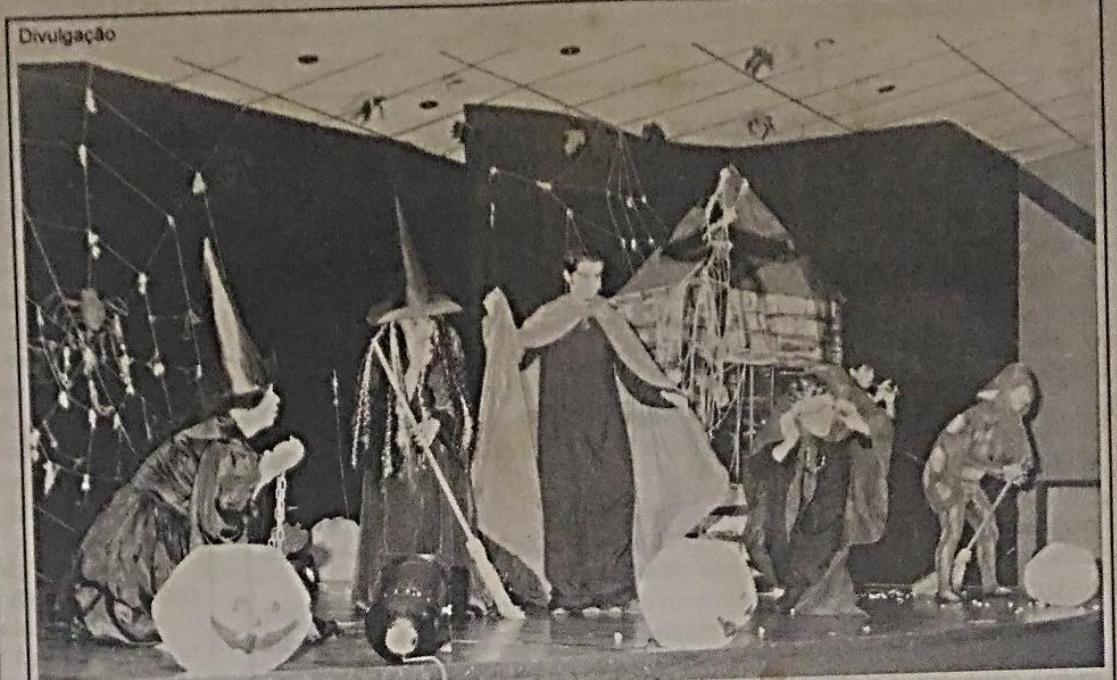

Apresentação da peça agradou o público, principalmente pela performance dos atores juvenis

"A bruxinha que era boa" contagia A peça infantil "A bruxinha que bado, apesar da chuva, mais de 300 nove adolescentes, era boa", apresentada no anfiteatro pessoas compareceram para assisdo Centro Universitário de Doura- tir a peça. No domingo, foi necesdos, Ceud, sábado e domingo pelo sário sessão extra para acomodar as dos, Ceud, sábado e domingo pelo sáris de mil pessoas que assistiram grupo de Teatro "Camaleão", da Funced, contagiou o público. No sá-

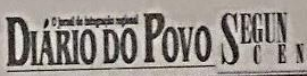

Jomal-Oprooresso - 2sde outubro 96

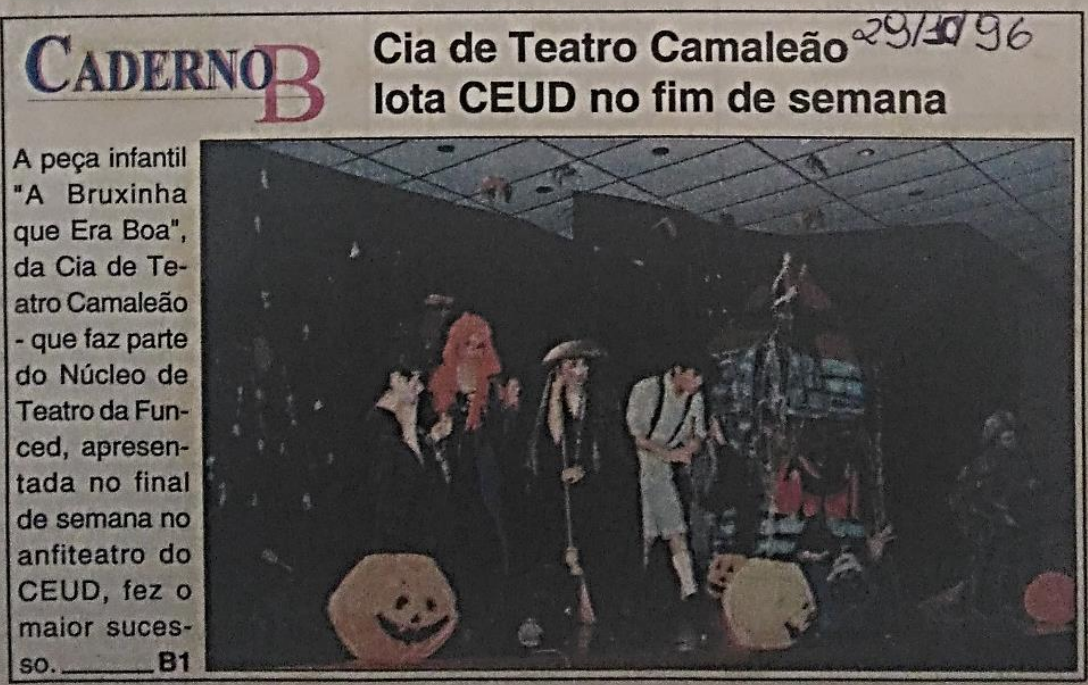

